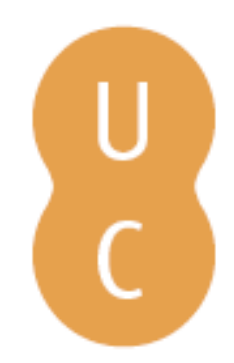

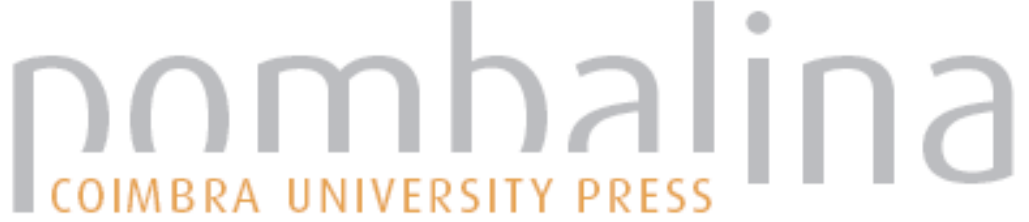

\section{A Faculdade de Filosofia Natural (1772-1911)}

Autor(es): $\quad$ Martins, Décio Ruivo

Publicado por: Imprensa da Universidade de Coimbra

URL

persistente: URI:http://hdl.handle.net/10316.2/38514

DOI: $\quad$ DOI:http://dx.doi.org/10.14195/978-989-26-0610-1_3

Accessed : $\quad$ 26-Apr-2023 01:58:57

A navegação consulta e descarregamento dos títulos inseridos nas Bibliotecas Digitais UC Digitalis, UC Pombalina e UC Impactum, pressupõem a aceitação plena e sem reservas dos Termos e Condições de Uso destas Bibliotecas Digitais, disponíveis em https://digitalis.uc.pt/pt-pt/termos.

Conforme exposto nos referidos Termos e Condições de Uso, o descarregamento de títulos de acesso restrito requer uma licença válida de autorização devendo o utilizador aceder ao(s) documento(s) a partir de um endereço de IP da instituição detentora da supramencionada licença.

Ao utilizador é apenas permitido o descarregamento para uso pessoal, pelo que o emprego do(s) título(s) descarregado(s) para outro fim, designadamente comercial, carece de autorização do respetivo autor ou editor da obra.

Na medida em que todas as obras da UC Digitalis se encontram protegidas pelo Código do Direito de Autor e Direitos Conexos e demais legislação aplicável, toda a cópia, parcial ou total, deste documento, nos casos em que é legalmente admitida, deverá conter ou fazer-se acompanhar por este aviso.

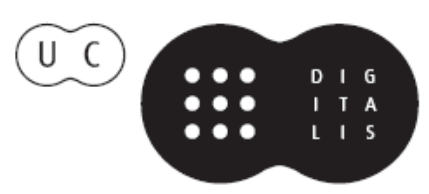



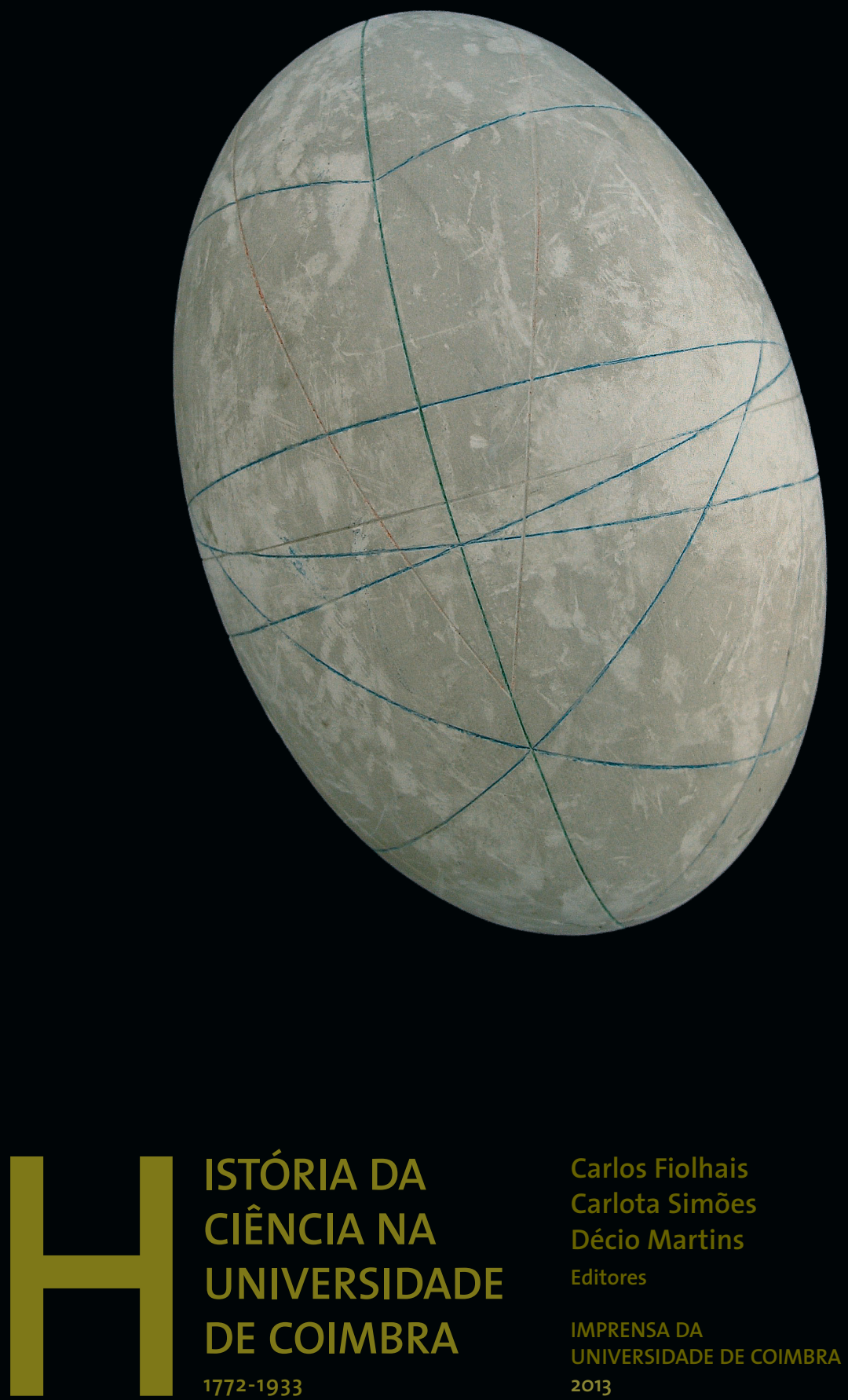

ISTÓRIA DA

CIÊNCIA NA

UNIVERSIDADE

DE COIMBRA

1772-1933
Carlos Fiolhais

Carlota Simões

Décio Martins

Editores

IMPRENSA DA

UNIVERSIDADE DE COIMBRA

2013 
Centro de Física Computacional. Universidade de Coimbra

A Faculdade de Filosofia Natural (1772-1911)

Décio Ruivo Martins

\section{Os Antecedentes da Reforma Pombalina}

A reforma pombalina da Universidade de Coimbra, em 1772, enquadrou-se numa profunda remodelação do sistema educativo em Portugal. As transformações introduzidas tiveram repercussões significativas no ensino das matérias científicas em geral. Os ideólogos da renovação foram muito vigorosos nas críticas feitas aos métodos pedagógicos e conteúdos programáticos dos antigos cursos de índole científica. De acordo com os promotores da reforma do ensino universitário, a Filosofia, que até então oficialmente se ensinava, mantinha uma influência profunda e decadente da Escolástica. Segundo a perspectiva dos mentores do novo projecto educativo, os temas de ensino eram exclusivamente dominados pelos arcaicos dogmas peripatéticos. As responsabilidades do alegado défice cultural e científico recaíram preferencialmente sobre as escolas da Companhia de Jesus. Para além dos professores jesuítas terem sido genericamente acusados de seguirem de um modo inflexível as ideias aristotélicas, também foram duramente censurados por não se isentarem em absoluto de um condenável e estéril confronto com outros tipos de saber, originados da praxis ou experiência científica. Argumentava-se que esta atitude pedagógica teve consequências profundamente nefastas na formação intelectual da juventude. $\mathrm{O}$ ensino das ciências, tal como se afirmava explicitamente nos Estatutos Pombalinos, era considerado miserável (Fig. 1). Uma das críticas mais intensamente expressas era que a aquisição do conhecimento mantinha uma dependência improfícua em relação a um saber sobretudo literário. A actividade intelectual era considerada acessível apenas àqueles que, livres de ocupaçôes materiais, podiam dedicar-se à leitura das grandes obras do passado, cujo conteúdo se limitava unicamente à espúria Filosofia Antiga. Deste modo, o conhecimento oficialmente difundido nas instituiçôes de ensino era considerado retrógrado e obsoleto.

Nesta época foram proferidas críticas muito incisivas, particularmente em relação ao estado do ensino das ciências físico-matemáticas. As análises condenaram a generalidade dos sectores de actividade pedagógica e intelectual, com especial relevo dado ao sistema de ensino praticado nas escolas da Companhia de Jesus, que vigorou até 1759. Em 8 de maio de 1770 Francisco de Lemos foi nomeado Reitor da Universidade, tomando posse no dia 29 do mesmo mês, cargo que exerceu até 1779. Juntamente com o irmão, João Pereira, foi nomeado pelo governo para fazer parte da Junta de Providencia Literária, criada por Carta 


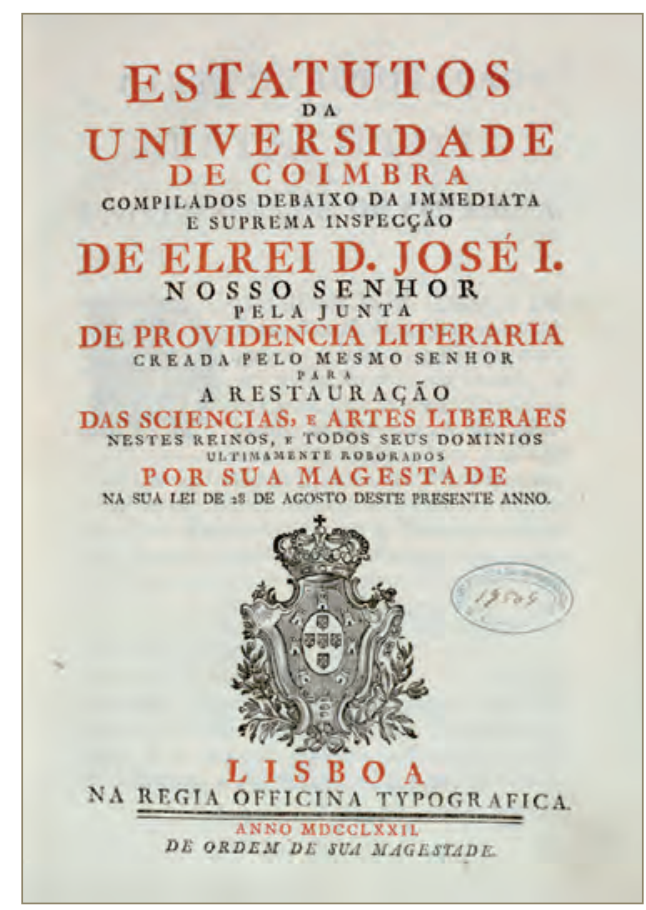

Figura 1 - Estatutos da Universidade de Coimbra/compilados debaixo da immediata e suprema inspecção d'el-Rei D. José I pela Junta de Providencia Litteraria.

Régia, em 23 de dezembro de 1770. Competia-lhe identificar as causas da decadência da Universidade e propor as medidas para a sua reforma sob a inspecção do primeiro presidente da Real Mesa Censória, o arcebispo de Évora, João Cosme da Cunha (Cardeal da Cunha) e do Marquês de Pombal. Em 1771 o diagnóstico teve um título eloquente: Compendio Historico do Estado da Universidade de Coimbra no tempo da invasão dos denominados jesuitas e estragos feitos nas Sciencias e nos professores, e directores que a regiam pelas maquinações, e publicações dos novos estatutos por elles fabricados. Pronunciando-se sobre a Filosofia Escolástica, que até então se considerava ter dominado o ensino no Colégio das Artes, e defendendo uma solução que colocasse a UC ao nível das melhores escolas europeias, Francisco de Lemos afirmou o seguinte: ${ }^{1}$

Como esta Filosofia [Peripatética], que com discredito da razão por tantos Seculos ocupou este nome só servia de deslocar o entendimento dos Homens, de corromper os estudos de todas as mais Faculdades, e de uma ruina geral das Artes; as quaes não podiam adiantar-se, e nem promover-se, por meio de uma Siencia verbal, toda destituida de conhecimentos Fizicos, e verdades certas na Natureza. Pareceu à Junta Literaria, que devia ser abolida não só da Universidade, mas também de todas as Escolas Publicas, e Particulares, Seculares e Regulares d'estes Reynos, e Senhorios.

\footnotetext{
${ }^{1}$ LEMOS, Francisco de, Relação Geral do Estado da Universidade de Coimbra (1777). fl. 108.
} 
Igualmente os oratorianos, que desde 1745 tinham promovido o ensino das ciências físico-matemáticas, sofreram um infortúnio idêntico ao dos jesuítas. No entanto, o alvo preferencial dos reformadores foi o curso de Filosofia do Colégio das Artes. A escola de Coimbra passou a ser identificada como o sector mais retrógrado da cultura científica portuguesa, classificada como o mais influente bastião da Filosofia peripatética. Particularmente os jesuítas que ensinavam naquele Colégio foram acusados de combaterem ferozmente qualquer intuito renovador da actividade científica e pedagógica até à sua expulsão de Portugal. Desde a época contemporânea de Galileu, as escolas jesuítas com maior destaque foram o Colégio de Santo Antão em Lisboa, o Colégio das Artes em Coimbra e a Universidade de Évora. Alguns estudos realizados sobre a actividade pedagógica dos jesuítas fazem notar que no Colégio das Artes não foi fácil admitir oficialmente o ensino das novas tendências científicas e filosóficas, sobretudo por motivos extrinsecos de outra ordem, que nada tinham a ver com as convicções ou com a competência científica e pedagógica de vários dos seus professores. $\mathrm{Na}$ verdade, uma das razóes fundamentais para um pretenso défice de desenvolvimento e de modernidade científica e pedagógica que oficialmente caracterizavam os seus cursos era de natureza estatutária. Os decrépitos Estatutos Universitários, pelos quais se regia o Colégio, impunham de um modo inflexível que se seguissem Aristóteles e as linhas mais clássicas do pensamento nos cursos que nesta escola eram professados. Com efeito, as determinações estatutárias constituíram um factor fundamental que, durante mais de um século, condicionou intensamente qualquer tentativa de inovação pedagógica. Esta situação limitativa não era, no entanto, do inteiro agrado daqueles professores que pretendiam rever e actualizar o seu ensino, desejando progredir particularmente nas ciências e admitir oficialmente nas suas aulas o estudo de novos pensadores. Dentro destes novos horizontes desencadeouse um plano geral de renovação no ensino da Filosofia nos Colégios da Companhia de Jesus, que constituiu uma espécie de manifesto oficial das novas tendências no ensino de Coimbra e Évora. A maior oposição encontrada pelos jesuítas em relação a qualquer tentativa de remodelação do ensino no curso de Filosofia verificou-se no Colégio das Artes.

A austeridade das críticas proferidas em 1772 teve um grande impacto, apesar de se poderem encontrar factos que comprovavam que nalguns cursos se tinha verificado uma significativa influência das modernas perspectivas científicas e pedagógicas que dominavam as principais escolas europeias. Com efeito, ao contrário das ideias propaladas para justificar o radicalismo das medidas tomadas, verificou-se que, apesar dos factores fortemente condicionantes, a Ciência emergente começou a ser introduzida nos cursos de Filosofia, Matemática e Astronomia, ao longo de todo o século XVII, desde os contemporâneos de Galileu, e no século XVIII, até ao ano de 1760. Apesar deste carácter inovador, a ideia que prevaleceu, consubstanciada nos documentos da Reforma Universitária, foi a da absoluta estagnação científica e letargia pedagógica dos jesuítas. Os Estatutos da Universidade de Coimbra de 1772 referiam-se de uma forma explícita aos aspectos considerados perniciosos do sistema de ensino vigente, dando especial ênfase ao pretenso estado letárgico e deplorável do ensino da Filosofia em geral e das ciências físico-matemáticas em particular.

$\mathrm{O}$ ambiente político e social que se viveu em Portugal nos finais da década de cinquenta e toda a década de sessenta, e que afectou seriamente a actividade científica e pedagógica dos jesuítas e oratorianos, teve profundas influências que condicionaram 
o ensino. Foi uma época assinalada por intervenções mais ou menos fervorosas, a favor e contra as novas perspectivas de pensamento e implantação de novas metodologias de ensino. Por vezes, o choque ideológico foi marcado por intervenções injuriosas e por retaliações pessoais. Por outro lado, o regime político dominante foi extremamente duro em relação aos espíritos mais independentes. Todos aqueles que não se vergaram sob a força do despotismo ministerial tiveram o seu futuro comprometido e a sua integridade pessoal ameaçadas. Só a prisão e o êxodo de várias personalidades, algumas forçadas, outras por se recusarem voluntariamente a viver no ambiente político instalado, levou a que, durante toda a década de sessenta, os níveis de ensino e de actividade científica tivessem, efectivamente, atingido a situação verdadeiramente miserável, como eram classificados nos Estatutos Pombalinos da Universidade. Foi durante esta década que se observou a total paralisação das actividades em várias escolas como o Colégio das Artes, Colégio de Santo Antão e Universidade de Évora. Também o Colégio da Casa das Necessidades, pertencente à Congregação do Oratório, acabaria por ser extinto em 1768, depois de um longo período de sete anos de dificuldades impostas pelo regime pombalino. Nesta escola tinham-se destacado no plano científico e pedagógico João Baptista, Teodoro de Almeida e João Chevalier. Este processo de atrofiamento intelectual e pedagógico foi acompanhado pelas perseguições, prisôes e condenaçôes ao exílio, feitas de um modo indiscriminado, atingindo um conjunto numeroso de intelectuais que, posteriormente, no estrangeiro, confirmaram o prestígio científico e pedagógico já anteriormente evidenciados em escolas portuguesas. Alguns destes intelectuais, que se dedicaram às ciências físico-matemáticas, viram o seu mérito reconhecido por várias das mais importantes academias científicas europeias. Este êxodo generalizado e extermínio de importantes sectores da vida intelectual, intensificados durante toda a década de sessenta, tinham colocado o país num absoluto e lamentável vazio pedagógico e científico. Só esta situação deplorável a que tinha sido reduzida a actividade cultural e científica justificou a necessidade de se recorrer a professores italianos para reactivarem alguns sectores do ensino que, entretanto, tinham sido completamente desmantelados desde finais da década de cinquenta. Foi nestas circunstâncias que vieram para Portugal os professores António Dalla Bella e Domingos Vandelli.

Para os promotores da reforma universitária, uma acção eficaz, que retirasse o ensino das ciências físico-matemáticas da situação considerada extremamente degrada e obsoleta em que se encontrava, só poderia ser concretizada através da eliminação radical das anteriores escolas e da criação de novos estabelecimentos de ensino. Para o efeito, ficou estabelecida como prioridade fundamental que se rompesse definitivamente e radicalmente com as causas do alegado insustentável e incorrigível atraso científico. As medidas mais importantes a pôr em prática deveriam conduzir à organização de novas unidades de ensino que estivessem em conformidade com as novas correntes pedagógicas que, ao longo do século XVIII, progressivamente se iam implantando na Europa. Estes novos estabelecimentos deveriam alargar os horizontes da cultura científica portuguesa, retirando-a da situação considerada deplorável em que se encontrava e aproximá-la dos padrôes dos países mais avançados. A nova Universidade deveria assumir a vanguarda científica e pedagógica, desempenhando um papel interveniente e com profundos reflexos na vida social, económica e tecnológica. Na apreciação que fez sobre o estado da Universidade de Coimbra, o Reitor Reformador, D. Francisco de 
Lemos, deixou bem expressa a sua opinião sobre a influência que a Universidade deveria ter no processo de desenvolvimento do país. Segundo ele, a organização do estudo das ciências naturais deveria ter como consequência desejável um melhor conhecimento das riquezas naturais, trazendo para a indústria novos recursos materiais. A concretização destes objectivos deveria constituir a base indispensável para o desenvolvimento do comércio. Os desígnios do novo projecto educativo deveriam fixar-se na consecução de um objectivo consequente de um ensino moderno - que a aprendizagem da metodologia experimental das ciências da natureza tivesse como resultado primordial o desenvolvimento de novas artes, novas manufacturas, novas fábricas, e o aperfeiçoamento das existentes. Para além da formação prática, os estudantes também deveriam obter uma formação teórica consentânea com os desenvolvimentos mais recentes da ciência. Para o efeito, deveriam ser organizados cursos onde estas duas componentes da formação fossem complementadas em cadeiras de especialidade.

O plano de reorganização do ensino das ciências na Universidade de Coimbra assentava nos pressupostos de uma total e radical ruptura com o passado. No entanto, foi uma personalidade que recebeu a sua formação académica nas escolas da Companhia de Jesus quem mais se destacou na organização dos estudos científicos nas recém criadas Faculdades de Philosophia e de Mathematica. Ao contrário das opinióes extremamente contundentes expressas nos Estatutos de 1772, este facto deixava antever que nem tudo, mesmo entre os jesuítas, correspondia ao lúgubre panorama apresentado de um modo indiscriminado em relação ao nível científico e pedagógico daqueles que se dedicaram ao ensino das matérias científicas até ao ano de 1759 . Na realidade, foi Monteiro da Rocha, que tinha obtido a sua formação científica nos Colégios da Companhia de Jesus, o principal mentor do programa de estudos das ciências físico-matemáticas da nova organização curricular universitária. A origem da sua qualificação científica e pedagógica, obtida em escolas tão intensamente combatidas pelos mais intransigentes críticos e oponentes do sistema educativo dos jesuítas, não impediu que se afirmasse como um dos mais notáveis e empenhados ideólogos e colaboradores na definição e concretização do plano pombalino da reforma universitária na área das ciências.

Com o plano de estudos delineado por Monteiro da Rocha, pretendia-se que o ambicioso projecto educativo de 1772 se concretizasse através de uma metodologia experimental, considerada inovadora no ensino das ciências físico-matemáticas. $\mathrm{O}$ estudo experimental era complementado por desenvolvimentos teóricos feitos em disciplinas devidamente programadas para esse fim. A Reforma Pombalina da Universidade trouxe uma nova dinâmica pedagógica e uma maior profundidade científica. As áreas de ensino tornaram-se mais abrangentes. As recém-criadas Faculdades de Philosophia e de Mathematica foram concebidas como unidades de ensino das ciências que apresentavam características de modernidade e de complementaridade pedagógica. Nestas duas Faculdades os temas científicos eram apresentados com considerável profundidade teórica e muito bom suporte experimental, particularmente nos assuntos de várias áreas relacionadas com a Física. Preconizava-se que as metodologias de ensino das ciências experimentais se fundamentassem em estratégias comparáveis às mais inovadoras que eram praticadas nas melhores escolas europeias. Duas das mais importantes realizações deste novo projecto educativo foram as criaçōes do Gabinete de Fysica Experimental e do Laboratório Chymico. O Gabinete de Física tem sido apon- 
tado ao longo da sua história como uma das mais relevantes realizações da Reforma Pombalina da Universidade, caracterizado pela sua modernidade e grandiosidade, bem como pela sumptuosidade artística dos seus instrumentos. Desde a sua origem foi equipado com instrumentos provenientes dos mais conceituados fabricantes europeus. O desenvolvimento que teve durante todo o século XIX, principalmente depois de 1850 , permitiu a reunião de uma numerosa colecção de instrumentos científicos bem representativos da evolução que teve a Física Experimental.

O Colégio de Jesus foi objecto de profundas obras de melhoramento para acolher o Gabinete de Física, o Museu de História Natural e o Hospital Público. A construção do edifício do Laboratório Químico, hoje sede do Museu de Ciência da Universidade de Coimbra, foi uma das mais importantes medidas da reforma universitária de 1772 (Fig. 2). Pombal tinha já antes planos claros para o Laboratório de Química, que foram trazidos de Viena de Áustria, a seu pedido, por Joseph Francisco Leal. Enquanto decorriam as obras no edifício, Vandelli ensinava em instalaçōes provisórias do extinto Colégio das Artes. Vandelli terá chegado a Portugal em 1764, com destino ao Colégio dos Nobres de Lisboa. Mas, tal como Dalla Bella, o professor italiano transferiu-se para Universidade de Coimbra em 1772.

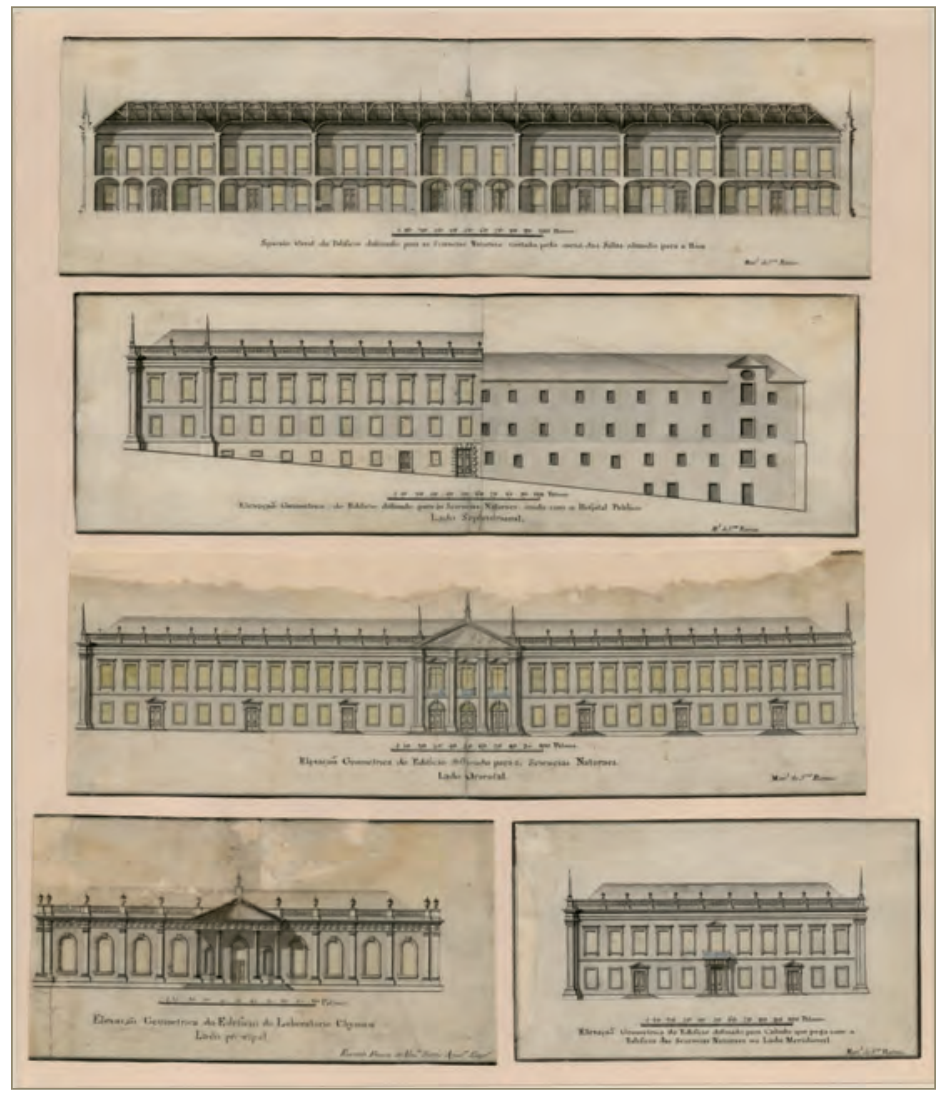

Figura 2 - Fachadas dos edifícios destinados às Ciências Naturais, Laboratório Chimico e Cabido. Material gráfico da autoria de Manuel de Souza Ramos; Ricardo Franco de Almeida Serra. [177-?]. 
Para além do Laboratório Químico, Vandelli esteve também ligado à elaboração de um plano de construção do Jardim Botânico, bem como ao acompanhamento da construção e instalação do Museu de História Natural. A criação em Coimbra de um jardim botânico era um anseio antigo. Já em 1731 tinha sido elaborado um projecto por Jacob de Castro Sarmento, baseado no pequeno Jardim do Chelsea Physic Garden, em Londres, que era um jardim para espécies farmacêuticas (Fig. 3). O novo plano do Jardim Botânico da Universidade de Coimbra foi delineado por Vandelli e Dalla Bella, ampliando o projecto anterior. Contudo, por o considerar extravagante e demasiado dispendioso, este plano não foi bem acolhido por Pombal. Assim, só em 1774 tiveram início as obras, junto à Universidade, segundo um plano mais modesto (Fig. 4). E foi só a partir de 1791 que o professor de Botânica e Agricultura Félix Avelar Brotero assumiu a direcção do Jardim, providenciando a aquisição de mais terreno de uma quinta próxima.

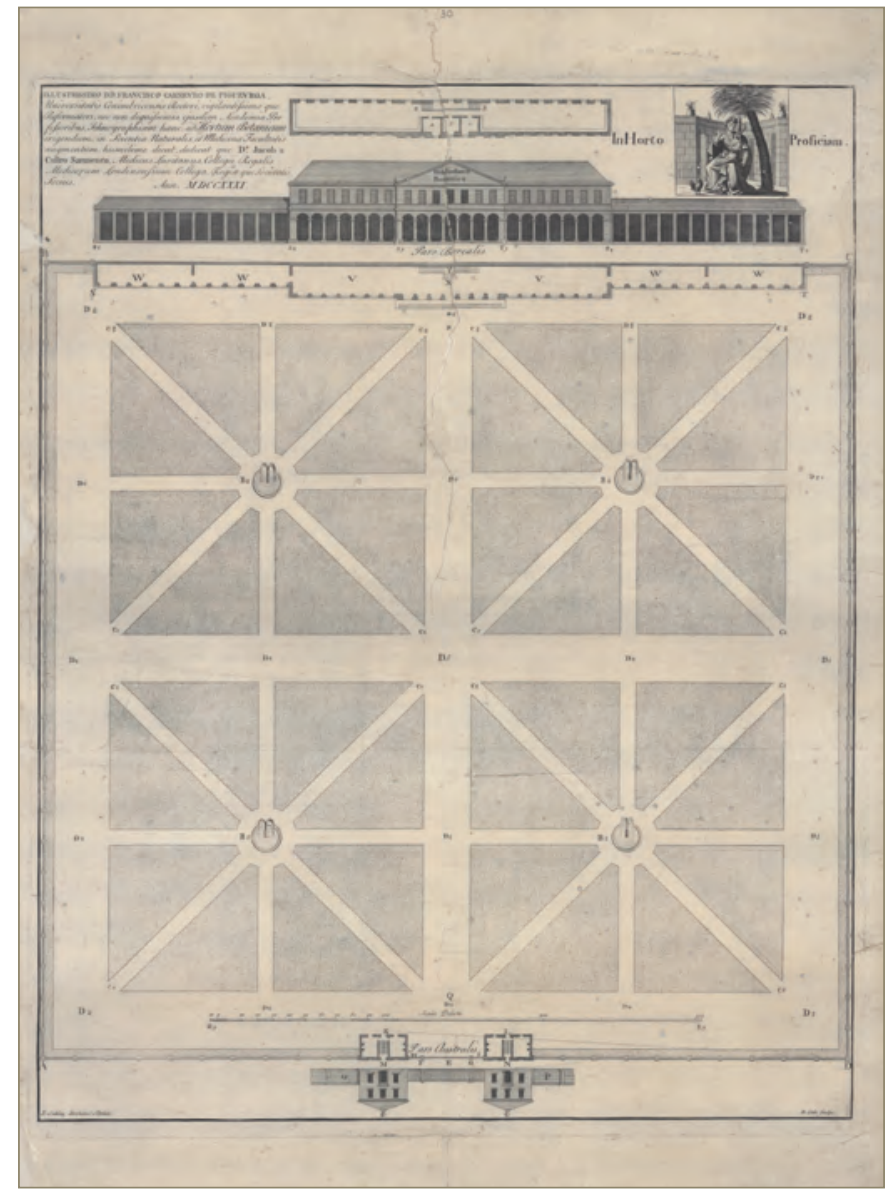

Figura 3 - Projecto, não executado, de Jardim Botânico e Biblioteca Botânica para a Universidade de Coimbra, concebido por Jacob de Castro Sarmento (1691-1760), dedicado a Francisco Carneiro de Figueiroa,

Reitor da Universidade. - Com legenda: “... Ichonographiam hanc ad Hortum Botanicum erigendum in Scientiae Naturalis et Medicinae Facultatis augmentum...”. 


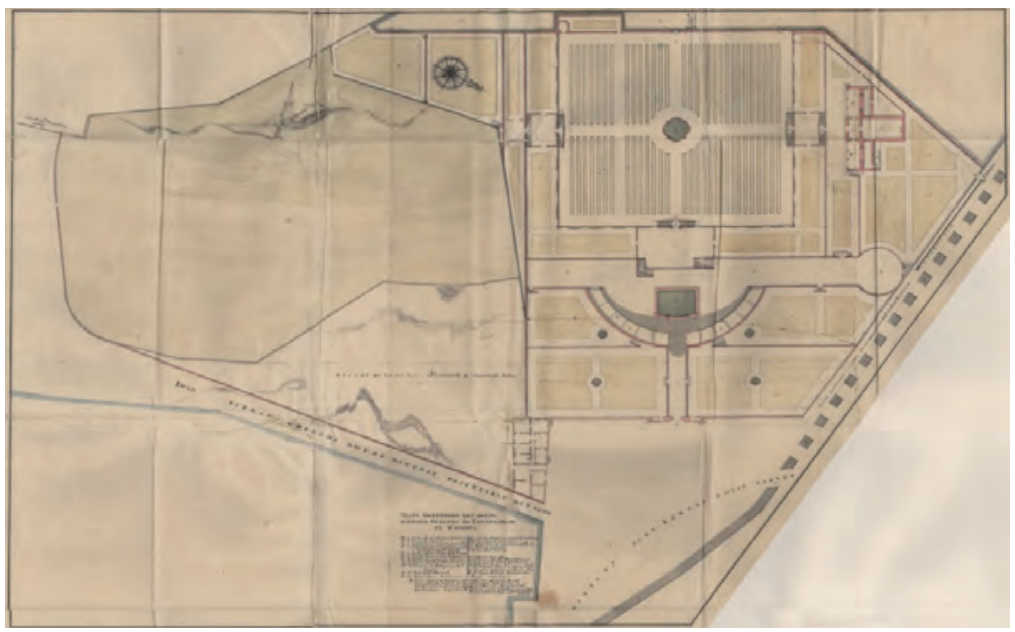

Figura 4 - Mapa do terreno ocupado pelo Jardim Botânico da Universidade de Coimbra por Manuel Alves Macomboa. - Set. (?) 1795.

As Faculdades de Philosophia e de Mathematica: Um projecto de ensino das ciências Físico Matemáticas

As Faculdades de Philosophia e de Mathematica apresentavam características complementares na formação científica dos estudantes. Esta complementaridade manteve-se nas sucessivas reformas curriculares, até à sua fusão, dando origem à Faculdade de Ciências em 1911. Com efeito, os estudantes do Curso Philosophico adquiriam conhecimentos fundamentais em Mathematicas Puras na Faculdade de Mathematica, antes de frequentarem a cadeira de Fysica Experimental e Chymica Theorica e Pratica, leccionadas na Faculdade de Philosophia. Posteriormente davam continuidade aos seus estudos nos aspectos teóricos da Física, frequentando a cadeira de Phoronomia, integrada no $4 .^{\circ}$ ano do plano curricular do Curso Mathematico. Por sua vez, os estudantes da Faculdade de Mathematica também frequentavam a cadeira de Fysica Experimental, leccionada no Curso Philosophico. Tanto para os estudantes do Curso de Philosophia como para os de Mathematica, a frequência desta cadeira era considerada uma base indispensável para os estudos posteriores das Sciencias Fysico-Mathematicas. O plano curricular da Faculdade de Philosophia de 1772 previa o estudo de Philosophia Racional e Moral no primeiro ano do curso. No segundo estudava-se História Natural e Geometria, estando o terceiro ano destinado à frequência das cadeiras de Physica Experimental e Cálculo, sendo concluído no quarto ano com a frequência nas disciplinas de Chymica Theorica e pratica e ainda a Phoronomia.

O ensino da Filosofia Experimental foi considerado pelos mais influentes ideólogos da Reforma do ensino como uma das necessidades mais urgentes da instrução pública em Portugal. Com a Reforma da Universidade de Coimbra em 1772, o Gabinete de Física Experimental surgiu integrado na Faculdade de Philosophia. A primeira colecção de instrumentos que o enriqueceu esteve intimamente ligada à extinção do estudo da Matemática e da Física no Colégio dos Nobres em Lisboa. Na sua origem podemos 
encontrar pressupostos pedagógicos que ainda hoje mantêm a sua validade. Nos Estatutos da Universidade, de 1772, pode lerse:

Para que as Liçôes de Fysica, que mando dar no Curso Filosofico da Universidade, se façam com aproveitamento necessário dos estudantes; os quaes não sómente devem ver executar as Experiencias, com que se demonstram as verdades até o presente, conhecidas na mesma Fysica; mas também adquirir o habito de as fazer com sagacidade, e destreza, que se requer nos Exploradores da Natureza; haverá também na Universidade huma Collecção das Máquinas, Aparelhos, e Instrumentos necessários para o dito fim.

Um dos objectivos para a criação do Gabinete de Física foi que se ministrasse o ensino da Física Experimental, através do qual se mostrasse o objecto desta ciência, a sua origem, progressos e as revoluções científicas que ao longo da história se observaram. Por outro lado, o desenvolvimento da competência individual no que respeita ao domínio do método experimental não foi esquecido. A arte de fazer as experiências, tendo-se a noção de como as repetir, combinar, distinguir os factos acessórios dos principais, bem como o controle de variáveis de que um sistema físico depende, constituíram uma das metas a atingir com a sua inclusão no plano de estudos do Curso Philosophico. O objectivo principal das experiências em que se deveria empenhar o professor era o de descobrir as leis gerais que regem a natureza nas suas operações. Não apenas o carácter qualitativo deveria estar contemplado no ensino ministrado.

Nos Estatutos Pombalinos da Universidade de Coimbra o conjunto das ciências Fysico-Mathematicas era considerado um ramo do conhecimento que tinha uma perfeição indisputável entre todos os conhecimentos naturais, caracterizada pela exactidão do método, bem como pela sublime e admirável profundidade de análise das suas doutrinas. Pelas suas características particulares, justificava-se que o seu estudo fosse considerado indispensável para a subsequente formação de todos os estudantes em geral. $\mathrm{O}$ entendimento de qualquer outra disciplina poderia atingir um elevado estágio de desenvolvimento, fundamentado no método das ciências matemáticas.

A diversidade de ciências que constituíam o conjunto das Mathematicas Puras e Mathematicas Mixtas dava origem a um extenso corpo de conhecimentos, cujo tratamento profundo tornava inviável que o seu estudo ficasse limitado no período de quatro anos do Curso Mathematico. Deste modo, o estudo das referidas ciências não poderia ir para além dos princípios fundamentais de cada uma delas. Assim, a profundidade dos estudos deveria ser a necessária e indispensável para que o estudante pudesse, por si mesmo, dar continuidade ao desenvolvimento posterior dos seus conhecimentos. Tendo por base o critério da formação que preparasse o estudante para o desempenho autónomo na progressão e aplicação dos seus conhecimentos, o Curso Mathematico tinha distribuído ao longo de quatro anos um conjunto de quatro cadeiras que serviam de base para as ciências mais específicas. A primeira cadeira era a de Geometria, onde se ensinava no primeiro ano os Elementos de Arithmetica, Geometria e Trigonometria Plana, com as respectivas aplicaçōes à Geodesia, Stereometria, etc. O segundo ano estava destinado ao estudo da Algebra, a qual contemplava o estudo do Cálculo Literal, ou Algebra Elementar, e os princípios do Cálculo Infinitesimal Directo e Inverso, considerando também a sua aplicação à Geometria Sublime e Transcendente. $\mathrm{O}$ estudo geral dos movimentos fazia-se no terceiro ano, na cadeira de Phoronomia. 
Nesta cadeira eram abordados todos os ramos desta ciência, que constituía o corpo das Sciencias Fysico-Mathematicas, como a Mecânica, Statica, Dynamica, Hydraulica, Optica, Dioptrica, etc. Por fim, no quarto ano ensinava-se, na cadeira de Astronomia, a teoria do movimento dos astros. Neste estudo estavam contemplados tanto os aspectos físicos como geométricos, procedia-se à prática do cálculo, observaçôes astronómicas, bem como eram desenvolvidos os estudos relativos às ciências que dependiam da Astronomia, como por exemplo a Cosmografia, Geografia, Hydrografia, Gnomonica, Chronologia, Pilotagem, etc.. Para o cumprimento da parte prática do programa da Cadeira de Astronomia Fysico-Mathematica ficou ordenado que se mandasse construir um edifício com condições ideais para a instalação do Observatório Astronómico. Após a sua conclusão deveria ser equipado com a melhor instrumentação proveniente dos mais qualificados fabricantes. Para além destas quatro cadeiras, os estudantes deveriam também frequentar uma cadeira de Desenho Civil e Militar. Esta cadeira, no entanto, não era considerada com o mesmo estatuto das restantes, por se considerar que nestas artes não havia a exactidão matemática que caracterizava todas as outras cadeiras que faziam parte do curso. Tratava-se de uma cadeira cujo ensino se desenvolvia através de um grande número de regras arbitrárias, e regia-se mais pelo bom gosto, do que pela demonstração.

Nas recém-criadas Faculdades de Philosophia e de Mathematica começaram por exercer a docência António Dalla Bella, Domingos Vandelli, António Soares Barbosa, Miguel Franzini, Miguel António Ciera, José Monteiro da Rocha, José Anastácio da Cunha. A partir de 1790 Félix de Avellar Brotero também deu um notável contributo para o desenvolvimento dos estudos científicos em Coimbra. Reorganizado o Curso de Filosofia, que até ao ano de 1759 tinha sido ministrado pelos jesuítas, no Colégio das Artes, houve que começar a recrutar entre os estudantes da nova Faculdade de Philosophia aqueles que no futuro viriam a ser os seus futuros docentes. Entre estes devemos destacar Vicente Coelho Seabra, José Bonifácio de Andrada e Silva, Manoel José Barjona, Thomé Rodrigues Sobral, Constantino Botelho de Lacerda, José Homem de Figueiredo Freire.

Uma das primeiras medidas do Marquês de Pombal para a organização do corpo docente da Faculdade de Mathematica, foi a nomeação de Monteiro da Rocha, por portarias de 3 e 7 de Outubro de 1772. Passou logo a reger a cadeira de Sciencias Physico-Mathematicas, e antes de se dedicar aos trabalhos originais que o tornaram célebre, traduziu compêndios franceses indispensáveis para a regência das aulas. Foi assim que traduziu e publicou em Coimbra, em 1773, os Elementos de Arithmetica, de Bezout, introduzindo-lhe alguns assuntos novos, onde se inclui um método especial para a extracção da raiz cúbica dos números, que ficou conhecido pelo nome de Methodo de Monteiro. Os Elementos de Arithmetica tiveram várias reimpressões, até 1826, e parece, que foi esta a última publicada. Traduziu também o Tratado de Mechanica, de Maria, de que houve várias ediçōes até 1812; O Tratado de Hydrodynamica, de Bezout, que se reimprimiu algumas vezes até 1813; o Elementos de Trigonometria Plana, de Bezout, publicado em 1774, adicionados com uma numerosa série de fórmulas, que tornaram este trabalho um dos mais abundantes e ricos entre os do seu género. Embora em nenhuma destas obras seja indicado o nome do tradutor, é certo que foi Monteiro da Rocha o seu autor. 
Em consequência de um ofício datado de 30 de Maio de 1776 para o reitor da Universidade, requisitando-lhe um dos lentes mais autorizados, Monteiro da Rocha foi também indicado para ser principal do Colégio dos Nobres de Lisboa, lugar que era provido por três anos. Em 16 de Janeiro de 1780 foi sócio fundador da Academia Real das Sciencias de Lisboa, tendo o cargo de director de classe. Publicou então várias memórias das quais se destacam as seguintes: Solução do problema de Kepler sobre a medição das pipas e tonéis; vem no tomo I das Memórias da mesma Academia; Additamento à regua de Mr. Fontaine para resolver por aproximação os problemas que se reduzem às quadraturas; nas citadas Memórias e tomo I; Determinação das orbitas dos cometas; idem tomo II.

José Anastácio da Cunha também exerceu a docência na Faculdade de Mathematica desde início. Pela consideração que lhe merecia, o Marquês de Pombal nomeou-o como lente da Faculdade de Mathematica, por provisão de 5 de Outubro de 1773, devendo ensinar a cadeira de Geometria. Com efeito, foi através de uma carta, datada de 5 de Outubro, que o Marquês de Pombal dava conhecimento ao Reitor Reformador, D. Francisco de Lemos, da seguinte informação do nomeado:

O dito militar é tão eminente na Sciencia Mathematica, que, tendo-o eu destinado para ir à Allemanha aperfeiçoar com o Marechal general, que me tinha pedido dois ou tres moços portuguezes para os tornar completos, me requereu o Tenente General Francisco Marican que o não mandasse, porque elle sabia mais que a maior parte dos Marechais de França, de Inglaterra e de Allemanha; e que é um d'aquelles homens raros que nas naçôes cultas costumam apparecer. Sobre estes e outros egualmente authenticos testimunhos foi provido na primeira cadeira do Curso Mathematico, attendendo à que nella não podem os professores das cadeiras maiores ensinar este anno tendo-a regido no precedente. A falta de gráu não lhe deve servir de impedimento porque alem de lembrar que o meu tio, o sr. Paulo de Carvalho, foi nomeado lente antes de ser doutor, se pode o dito professor doutorar da mesma maneira que se doutoram os outros professores depois de nomeados lentes.

Em ofício do Marquês, dirigido ao Prelado da Universidade, datado de Oeiras em 15 de Outubro de 1773, afirmavase que:

Tenho por certo, que o Professor de Geometria ha de fazer uma boa parte do ornamento litterario d'essa Universidade, e que com o genio suave que se lhe conhece, conduzirá os seus discipulos a aprenderem com gosto e diligencia uma disciplina, tão proveitosa como esta para todas as Faculdades positivas.

Foi breve a carreira académica de José Anastácio em Coimbra, porquanto, no princípio do reinado de D. Maria I, sendo denunciado ao Tribunal da Inquisição por causa das suas opiniões religiosas, foi preso no $1 .^{\circ}$ de Julho de 1778 e penitenciado depois por aquele tribunal por sentença de 15 de Setembro, confirmado pela mesa do conselho geral de 6 de Outubro do mesmo ano. Como consequência deste processo foi condenado à reclusão na casa de Nossa Senhora das Necessidades. O intendente geral de polícia da corte, Diogo Ignacio de Pina Manique, reconhecendo o mérito de José Anastácio, e pretendendo de algum modo remediar a injustiça de que foi vítima, conseguiu do governo que fosse nomeado como professor na Real Casa Pia do Castelo de S. Jorge, denominada de S. Lucas, instituição vocacionada para educação dos órfăos e meninos pobres. 
Além dos Principios Mathematicos existem duas obras póstumas de Anastácio da Cunha publicadas pela imprensa - Ensaios sobre os principios de mechanica, dada à luz por Domingos António de Sousa Coutinho, possuidor do manuscrito autografo, Londres, 1807; Carta physicomathematica sobre a theoria da polvora em geral, e determinação do melhor comprimento das peças em particular, escripta por José Anastacio da Cunha, em 1769, Porto, Typographia Commercial Portuense, 1838. Foi publicada por dois ilustres antigos estudantes da Faculdade de Mathematica, José Victorino Damazio e Diogo Kopke. O Ensaio sobre os principios de mechanica foi reimpresso no volume $4 .^{\circ}$ do Instituto de Coimbra; e no volume $5 .^{\circ}$ do mesmo jornal foram publicadas as Notas ao Ensaio, de Silvestre Pinheiro Ferreira, as quais primitivamente tinham sido impressas em Amsterdão no ano de 1808. Nestas notas Silvestre Pinheiro afirmava que José Anastácio escrevera o Ensaio a rogo do seu discípulo e admirador, Manuel Pedro de Mello. Além destas obras ficaram em poder de João Manuel de Abreu outras manuscritas, que não chegaram a ser publicadas.

\section{A Chimica em Coimbra no Final do Século XVIII}

Com a Reforma Pombalina da Universidade a Química emergiu em Portugal, caracterizando-se por um importante desenvolvimento. O ensino da Química deveria passar por um resumo abreviado da história da Ciência, mostrando a sua origem e respectivos progressos, as revoluçóes, sucessos e decadências que conheceu, o descrédito com que a cobriram os alquimistas, e, finalmente, a sua restauração, para bem das artes que dela dependem. Estabeleciam com clareza o objecto da Filosofia Química, esclareciam as razões da inserção da Química no Curso Filosófico e eram explícitos na definição do conteúdo programático. Para que as experiências relativas ao curso das liçôes fossem realizadas com o bom proveito dos estudantes, foi criado um laboratório, onde se trabalhasse assiduamente nas preparaçōes químicas destinadas ao uso das artes em geral e da medicina em particular. A Química foi instituída como disciplina autónoma que integrava o Curso Filosófico, com o objectivo de indagar as propriedades particulares dos corpos: analisando os seus principios, examinando os elementos de que se compóem e descobrindo os efeitos e propriedades relativas que resultam da mistura e aplicação intima de uns aos outros.

Estatutariamente e programaticamente, a ciência química que se ensinava era, do ponto de vista teórico, uma química flogística, seguindo aquilo que era dominante nos diversos países da Europa. Do ponto de vista prático, caracterizava-se como uma ciência alicerçada sobre dados experimentais e método experimental. A teoria do flogisto, utilizada durante muito tempo na interpretação dos fenómenos químicos conhecidos, nomeadamente da combustão, foi desenvolvida por Stahl, que tratou as suas ideias fundamentalmente em duas obras intituladas: Experimenta, Observationes, chymicae et physicae, publicada em 1697, e Traité du Soufre, publicado em 1717.

A Reforma Pombalina emerge quando, em França, Lavoisier lançava os fundamentos de uma profunda reformulação da Química como ciência. Foi através desta reforma universitária que em Portugal, no último quartel do século XVIII, se seguiu a par e passo os progressos desta ciência além fronteiras, procurando também ela dar 
o seu contributo para a resposta às principais questôes que então se punham no seu domínio. Este período é alicerçado na obra de homens totalmente empenhados nesta ciência: inicialmente com Domingos Vandelli (1730-1816), Manoel Joaquim Henriques de Paiva (1752-1829) - fiéis à teoria do flogisto e segundo à orientação traçada por Stahl - e depois com Thomé Rodrigues Sobral (1764-1829) e Vicente Coelho Seabra Telles (1764-1804) - introdutores da química nova, a química pneumática da escola de Lavoisier. Inicialmente notam-se as influências de obras de referência como as Institutiones Chemia de Jacob Spielmann, editada em 1766, e os Fundamenta Chemia de Giovanni Scopoli, editada em 1777, defensores da teoria do Flogisto. A evolução em Coimbra ocorreu no sentido de um acompanhamento actualizado da Química pneumática e do oxigénio da Escola de Lavoisier. "Química Pneumática», "Química do Oxigénio», são dois termos usados para referenciar o sistema químico de Lavoisier.

Domingos Vandelli exerceu a sua actividade num período em que afloravam as novas doutrinas de Lavoisier, sem a elas aderir, mantendo-se sempre fiel às teorias do Flogisto. Nem o facto de haver dentro da Faculdade de Filosofia quem clamasse com grande insistência a necessidade de se abandonar tais teorias o conseguiu demover delas a favor das teorias de Lavoisier.

Vicente Coelho Seabra e Telles destacou-se entre os primeiros nomes de estudantes distintos formados pela nova Faculdade de Filosofia. No mesmo ano da sua formatura publicou a Dissertação sobre a Fermentação em Geral, e suas Espécies (Fig. 5). Este trabalho publicado em 1787 pela Real Impressão da Universidade é considerado como o primeiro escrito em português em que se defende a decomposição da água "em gaz inflammável, e ar puro, ou oxyginio", de acordo com as teses que vinham sendo sustentadas pela escola de Lavoisier. No ano seguinte, Vicente Coelho publicou o primeiro volume dos Elementos de Chimica (Fig. 6), onde escreve sobre a confirmação da composição da água pelas experiências realizadas no Laboratório Chimico da Universidade de Coimbra. Foi nesta obra que o químico português tomou uma das mais radicais posiçóes que se conhece contra o flogisto, declarando que...

\section{«... a theoria stabliana moderna he sem fundamento»}

interrogando-se

"porque razão o repto o phlogisto de Stahl há de entrar em tudo quanto há em chimica com as máscaras, que lhe quisermos dar? Porque não entrará somente, quando deve, a matéria do calor, luz ou fogo? Para quê romances, quando há factos? Para quê sonhar ou conjecturar, quando não he preciso?»

Os químicos de Coimbra acompanharam com actualidade os estudos de Lavoisier sobre a natureza da água. O testemunho escrito de que os químicos de Coimbra também realizaram experiências de síntese da água, veio pela palavra de Vicente Coelho de Seabra, que no seu Elementos de Chimica declarou que...

«...esta experiência foi repetida no nosso Museu de baixo da inspecção dos Douctores Vandelli, Sobral e outros». 


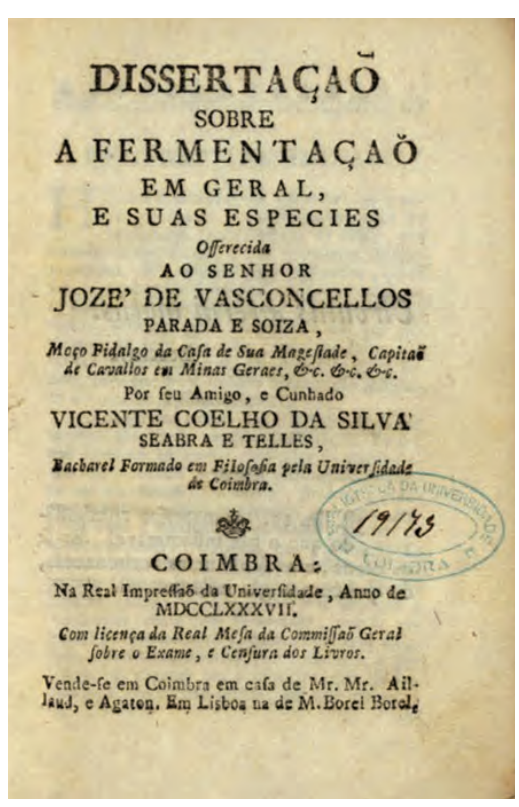

Figura 5 - Dissertaçaô sobre a fermentaçaõ em geral, e suas especies de Vicente Coelho da Silva Seabra e Telles. - Coimbra: na Real Impressaó da Universidade, 1787.

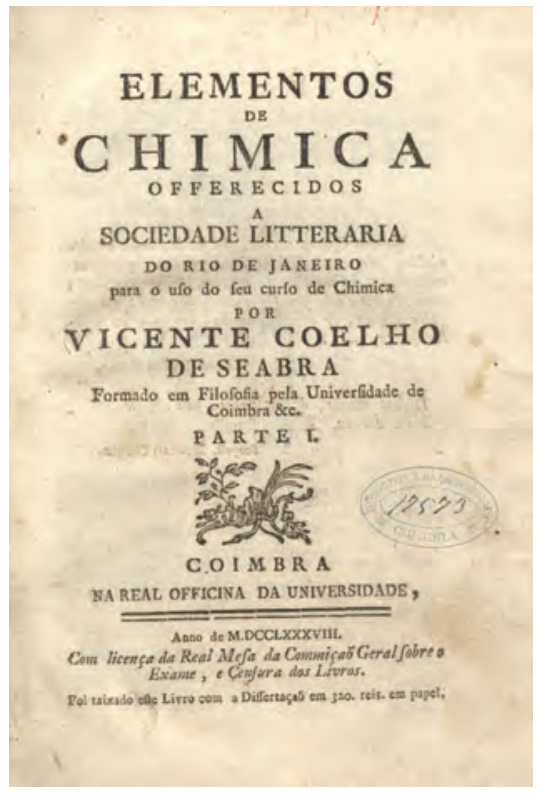

Figura 6 - Elementos de chimica de Vicente Coelho da Silva Seabra e Telles. - Coimbra: na Real Officina da Universidade, 1788-1790.

O desenvolvimento da Química dos gases está particularmente associado ao estudo da variação de peso por parte dos metais nos processos de combustão e calcinação. A individualização do oxigénio, do azoto, do hidrogénio, do dióxido de carbono, etc., juntamente com a determinação da verdadeira natureza e composição do ar atmosférico e da água, são a base sólida que levaria ao triunfo definitivo da nova química de Lavoisier. É neste estudo que se inserem as primeiras experiências com balôes aerostáticos. Também neste domínio os químicos de Coimbra acompanharam a evolução dos acontecimentos. Neste contexto se insere a experiência realizada, em Junho de 1784, por docentes e estudantes da Universidade, cerca de sete meses depois da primeira experiência dos irmãos Montgolfier.

O entusiasmo e interesse com que Domingos Vandelli e seus mais eminentes discípulos seguiam a revolução científica então em curso no domínio da Química e marcou uma época florescente e memorável em Portugal. A actividade do Laboratório Química, principalmente fomentada por Thomé Rodrigues Sobral no ensino e prática da química, cedo atraiu discípulos notáveis, entre os quais se destacaram, para além de Vicente de Seabra, Manuel José Barjona e José Bonifácio de Andrada e Silva, cujos nomes se distinguiram na química e mineralogia.

O nome de Domingos Vandelli está ligado às origens da indústria da cerâmica portuguesa no período pombalino. Um facto histórico que terá sido determinante para o início da produção de porcelanas em Portugal, sob o impulso de Vandelli foi um alvará régio de 7 de Novembro de 1770 limitando a importação de loiça estrangeira. Esta determinação pombalina enquadrava-se num programa de impulso 
e protecção à cerâmica portuguesa, concretizada com a criação da Fábrica da Louça do Rato. Desde cedo o empenho de Vandelli neste projecto se fez notar. Precisamente no ano da Reforma Pombalina da Universidade solicitava o apoio de Melo Pereira e Cáceres, Governador de Mato Grosso, no Brasil, para proceder à prospecção de todas as espécies de terras adequadas ao fabrico e pintura de loiça. Nos anos que se seguiram encontramos o químico italiano absorvido no ambicioso projecto da reforma universitária, particularmente nos projectos de criação do Laboratório Chimico, do Theatro Natural e dos Museus, e ainda do Horto Botânico. Apenas em 1780, depois de terminadas as obras dos novos estabelecimentos da Universidade, Vandelli dá início a um novo projecto, tendo apresentado para o efeito uma petição para a reconversão da Fabrica de Telha Vidrada inicialmente instalada em Coimbra, na Rua João Cabreira, junto ao Rio Mondego, para a produção dos diversos materiais usados na construção dos novos edifícios universitários. A concessão da antiga fábrica foi atribuída no dia 20 de Dezembro de 1780, sob a condição do pagamento do respectivo aluguer a partir de 1 de Janeiro de 1781. A antiga fábrica estava sedeada em casas pertencentes a particulares aos quais a Universidade pagava a respectiva renda. $\mathrm{Na}$ Congregação de 12 de Janeiro de 1781 Vandelli apresentou o projecto da nova fábrica da loiça. Nesta proposta era apresentada uma solução para o pagamento do aluguer das instalações. Não tendo havido anuência por parte da Rainha quanto ao modo de recolha das verbas necessárias para o cumprimento das despesas do aluguer das instalações, verificou-se uma situação de incumprimento, até que em 1782 os respectivos proprietários reclamassem os respectivos direitos junto da Universidade, a verdadeira arrendatária das instalações. Este diferendo prolongou-se até 1784 , com a progressiva degradação das instalações, situação que se manteve até Junho de 1786 comprovada por um despacho do Reitor da Universidade, confirmando a ameaça de ruína iminente das antigas instalações. O edifício foi vendido, por arrematação, no dia 13 de Novembro de 1790.

Entretanto, Vandelli ter-se-á voltado para outro projecto. Fundou em 1784, no Rocio de Santa Clara uma outra fábrica, que segundo se admite, terá sido de propriedade exclusiva do químico italiano, a qual se tornou famosa pelo fabrico da mais fina qualidade de faiança de Coimbra, conhecida pela designação popular de louça de Vandel ou louça de Vandelles.

\section{A Faculdade de Filosofia no Início do Século XIX}

A evolução do ensino em Portugal foi muito influenciada pelas transformaçôes sociais e políticas observadas em França. A lei de 27 de Setembro de 1794 decretou a criação em Paris de uma escola destinada ao ensino técnico. Jacques Elie Lomblardie, director da Escola de Pontes e Calçadas, concebeu um projecto de ensino científico e técnico geral destinado a engenheiros. Esta ideia foi comunicada a Monge, que com o auxílio de Carnot e Prieur, fez com que um novo projecto educativo fosse aprovado pelo Comité de Salvação Pública. Fourcroy foi encarregado da organização da nova unidade de ensino, a qual viria a ser instituída com a designação de Escola Central de Trabalhos Públicos. Por decreto de 1 de Setembro de 1795 passou a ser denominada Escola Politécnica. Esta nova escola modelar passou a representar uma significativa 
abertura do ensino face à imutabilidade tradicional das Universidades. O ensino da Física Experimental na Escola Politécnica de Paris viria a constituir uma das mais importantes referências de ensino desta disciplina em Coimbra ao longo de todo o século XIX. Por outro lado, no final do século XIX, a organização universitária na Europa viu-se obrigada a grandes reformas de organização, sendo paradigmático o caso da Universidade Humboldt de Berlim, fundada em 1810, que já foi chamada "the mother of all modern universities". Tratava-se, com efeito, de um centro aberto à investigação científica como trabalho complementar ou mesmo autónomo da docência universitária. Na primeira metade do século XIX verificaram-se na Universidade de Coimbra algumas reformas curriculares (sendo as mais importantes as de 1801, 1836 e 1844), da iniciativa do próprio claustro universitário, como necessidade de melhor ajustamento ao desenvolvimento científico na Europa. No entanto, apesar das sucessivas reformas curriculares tendentes à actualização dos conteúdos científicos dos programas de ensino, não se pode dizer que ela tenha sido palco de descobertas ou desenvolvimentos relevantes à escala europeia. A partir de 1836/37, com a fundação da Escola Politécnica de Lisboa e da Academia Politécnica do Porto, imbuídas do espírito do liberalismo, a Universidade de Coimbra passou a ter concorrência a nível de estudos superiores. A relação entre essas várias escolas não foi simples. Alguns críticos afirmaram que os métodos de ensino coimbrão continuavam a assentar nas lições magistrais e na erudição livresca e, consequentemente, não eram mais do que um repositório de uma ciência desligada das realidades técnicas e como fábrica de homens políticos que cobiçavam os graus académicos para a conquista de situaçôes proeminentes.

Ao longo do século XIX as Faculdades de Philosophia e de Mathematica tiveram as suas actividades suspensas em consequência da instabilidade política e social. A Universidade esteve encerrada nos anos lectivos de 1810/1811; de 1828/1829; de 1831 a 1834 e de 1846/1847. A Tabela I mostra o número de estudantes que entre os anos de 1790 a 1872 estiveram matriculados na Faculdade de Mathematica. A Tabela II apresenta o número de estudantes que entre 1800 e 1872 estiveram matriculados no Curso de Philosophia.

Depois da Reforma Pombalina da Universidade de Coimbra, no ano de 1791 verificou-se a primeira alteração do plano de estudos na Faculdade de Filosofia. Com efeito, por carta régia de 24 de Janeiro foi criada a cadeira de Botânica e Agricultura, para substituir a de Filosofia Racional, que os estatutos haviam incorporado no primeiro ano do Curso Philosophico. Para reger a nova cadeira de Botânica foi nomeado Félix de Avellar Brotero, que por carta régia da mesma data se graduou gratuitamente, e entrou na corporação da Faculdade. Brotero havia estudado no Colégio dos Religiosos Arrábicos de Mafra, tendo posteriormente concorrido, em 1763, ao lugar de capelão cantor da Igreja Patriarcal de Lisboa. Em 1778, emigrou para França na companhia de Filintio Elísio. Em Paris, dedicou-se ao estudo das ciências Naturais, frequentando os cursos de Valmont de Bomare e Buisson. A sua estadia na capital francesa permitiu-lhe conviver com os mais eminentes naturalistas franceses, especialmente com Buffon, Cuvier e Lamark. Doutorou-se em medicina, na Universidade de Reims. Em 1790 regressou a Portugal. Tendo sido nomeado professor da Faculdade de Filosofia, foi determinante a sua intervenção para a reforma do plano de estudos que em 1791 levou à criação da cadeira de Botânica e Agricultura. 


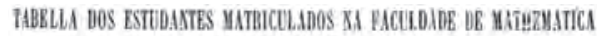
DESDR 1790 ATE 1872

\begin{tabular}{|c|c|c|c|c|c|}
\hline AsNos & 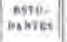 & Awros & 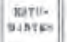 & Axsos & $\begin{array}{l}\text { rarc- } \\
\text { Denik: }\end{array}$ \\
\hline 1790 a 1791 & $3: 12$ & 1817 a 1818 & 188 & 1847 a 1848 & 90 \\
\hline 1791 « 1798 & 238 & 1818 a 1819 & 206 & 1848 a 1849 & 112 \\
\hline 1792 а 1793 & 185 & 1819 a 1820 & 118 & 1849 д 1850 & 135 \\
\hline 1973 a 1794 & 130 & $1820 \div 1821$ & 199 & 1850 a 1851 & 118 \\
\hline $1794 \times 1795$ & 212 & 1821 a 1822 & 217 & 1851 a 1859 & 111 \\
\hline 1795 × 1796 & 191 & 1822 a 1823 & 255 & 1852 a 1853 & 141 \\
\hline 1796 a 1797 & 183 & $1823,: 821$ & 187 & 1853 a 1854 & 118 \\
\hline 1797 × 1798 & 159 & 1824 แ 1825 & 159 & $185+31855$ & 131 \\
\hline 1798 × 1790 & 172 & 1325 a 1826 & 169 & 1855 a 1856 & 143 \\
\hline $1790 \times 1600$ & 246 & 1826 a 1827 & 158 & 1856 n 1657 & 62 \\
\hline 1800 a 1801 & 247 & 1827 a 1828 & 147 & 1857 n 1858 & 92 \\
\hline 1801 a 1602 & 239 & 1829 « 1830 & $9 ! j$ & 1858 1859 & 134 \\
\hline 1802 a 1800 & 259 & 1830 a 1831 & 29 & 1859 1860 & 107 \\
\hline 1803 a 1804 & 226 & 1834 A 1835 & 75 & 1860 a $: 861$ & 121 \\
\hline 1804 a 1805 & 210 & 1835 a 1836 & 164 & 1861 \% 1862 & 120 \\
\hline 1805 а 1806 & 155 & $18: 56$ a 1837 & 189. & 1862 a 1863 & 90 \\
\hline 1806 a 1807 & 130 & 1837 แ $18 ? 3$ & 133 & 1803 a 1864 & 99 \\
\hline 1807 a 1808 & 85 & 1835 a $185 y$ & 142 & 1864 a 1865 & 84 \\
\hline 1808 a $\operatorname{Li} 09$ & 52 & 1839 А 1840 & 108 & 1865 a 1866 & 74 \\
\hline 1809 a 1810 & 44 & 1840 a 1841 & 96 & 1866 a 1867 & 67 \\
\hline 1811 a 1812 & 38 & 1841 a 1849 & 112 & 1867 a 1868 & 98 \\
\hline 1812 a 1813 & 45 & 1842 a 1843 & 160 & 1868 a 1869 & 105 \\
\hline 1813 a 1814 & 50 & 1843 a 1844 & 101 & 1869 a 1870 & 103 \\
\hline $1814 \times 1815$ & 61 & $1844 \approx 1845$ & 94 & $1670_{4} 1871$ & 114 \\
\hline 1816 a 1816 & 76 & 1845 \& 1846 & 113 & 1871 a 1872 & 121 \\
\hline 1816 и 1817 & 120 & & & & \\
\hline \multicolumn{6}{|c|}{ 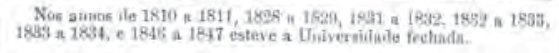 } \\
\hline
\end{tabular}

TABELA I - Estudantes matriculados na Faculdade de Matemática.
TABELIA DOS ESTODANTES MATRICULADOS DESDE $1800-1801$ ATE $1871-1872$

\begin{tabular}{|c|c|c|c|c|c|}
\hline A abes & $\begin{array}{c}\text { Eaty- } \\
\text { danies }\end{array}$ & Sнะе & $\begin{array}{l}\text { Eats- } \\
\text { dinies }\end{array}$ & Awaon & $\begin{array}{l}\text { Bary. } \\
\text { Aantes }\end{array}$ \\
\hline 1800 a 1801 & 211 & 1824 a 1825 & 151 & 1801 a 1852 & 163 \\
\hline 1801 а 1802 & 203 & 1825 a 1826 & 161 & 1852 a 1853 & 181 \\
\hline $1802 \times 1803$ & 206 & 1820 a 1827 & 185 & $185 \overline{3}$ a 1854 & 160 \\
\hline 1803 a 1804 & 176 & 1827 a 1828 & 165 & 1854 a 1855 & 264 \\
\hline 1804 a 1805 & 133 & 1829 a 1830 & $30 \bar{~}$ & $18 \check{1}$ a 18506 & 212 \\
\hline 1805 a 1806 & 146 & 1830 a 1831 & 20 & 1856 a 1857 & 96 \\
\hline 1806 a 1807 & 197 & 1834 a 1835 & 86 & 1857 a 1858 & 136 \\
\hline 1807 a 1808 & 112 & 1835 a 1836 & 172 & 1850 & 171 \\
\hline 1808 a 1509 & 46 & 1836 a 1837 & 186 & 1860 & 157 \\
\hline 1811 a 1812 & 34 & 1837 a 1838 & 170 & 1860 a 1861 & 171 \\
\hline 1812 a 1813 & 44 & 1838 a 1839 & 171 & 1861 a 1862 & 256 \\
\hline 1813 a 1814 & 40. & 1834 a 1840 & $1: 39$ & 1862 a 1863 & 195 \\
\hline $1814 \div 1815$ & 305 & 1840 a 1841 & 100 & $1863 \times 1364$ & 215 \\
\hline 1815 a 1816 & 76 & 1841 a 1842 & 100 & 1864 a 1865 & 106 \\
\hline 1816 a 1817 & 86 & 1842 a 1843 & 114 & 1865 a 1866 & 170 \\
\hline 1817 a 1816 & 129 & 1843 a 1844 & 126 & 1866 a 1867 & 129 \\
\hline 1818 a 1819 & 166 & 1844 a 1845 & 184 & 1867 a 1868 & 189 \\
\hline 1819 a 1820 & 151 & 1845 a 1846 & 104 & 1868 a 1869 & 235 \\
\hline $18 \div 0 \times 1821$ & 152 & 1847 a 1848 & 103 & 1869 a 1870 & 254 \\
\hline 1821 a 1822 & 207 & 1846 a 1849 & 122 & 1870 a 1871 & 260 \\
\hline 1822 a 1823 & 208 & 1849 a 1850 & 156 & 1871 a 1872 & $2 ! 7$ \\
\hline 1823 a 1824 & 193 & 1850 a $185 !$ & 132 & & \\
\hline
\end{tabular}

TABELA II - Estudantes matriculados na Faculdade de Filosofia.

Brotero foi membro de várias academias científicas internacionais, entre as quais a Sociedade de Horticultura e a Linnean Society, as duas de Londres, a Academia das Ciências de Lisboa, de História Natural e Filomática de Paris, Fisiográfica de Lund, de História Natural de Rostock, e Cesareia de Bona. Entre os seus trabalhos refiram-se: Compêndio de Botânica de 1788 (Fig. 7), Flora Lusitanica..., publicada em 1804 (Fig. 8); Phytographia Lusitaniae selectior... (1816-1827), e Compêndio de botânica... (1837-1839). Também publicou diversos artigos nas Transactions of the Linnean Society. Com toda essa obra, Brotero foi talvez o mais proeminente cientista português do século XIX.

Nova reforma do plano de estudos do Curso Phiplosophico viria a ocorrer em 1801, para a qual foi decisiva a intervenção de José Bonifácio de Andrada e Silva. Com efeito, nesta reorganização curricular foi instituída, por carta régia de 21 de Janeiro, a cadeira de Metalurgia, para se ler no quarto ano conjuntamente com a cadeira de Agricultura, unindo-se novamente o ensino da Botânica ao curso da História Natural. Pela mesma carta régia foram criados mais dois lugares de substitutos ordinários, e um demonstrador para o curso de Metalurgia.

No Brasil, sua terra natal, José Bonifácio é recordado como o Patriarca da Independência. Em Portugal é salientado o carácter de notável pedagogo e cientista, onde deixou uma importante obra, para além de todo o empenho que dedicou à luta contra a ocupação francesa. Nasceu no dia 13 de Junho de 1763. Concluídos os seus primeiros estudos, veio para Portugal quando contava pouco mais de dezoito anos. $\mathrm{Na}$ Universidade de Coimbra frequentou os cursos de Filosofia e de Direito, nos quais se formou ao fim de seis anos. Foi um dos primeiros estudantes depois da Reforma Pom- 
balina a evidenciar notáveis aptidões científicas, adquirindo mesmo algum prestígio internacional. Após a conclusão dos seus cursos em Coimbra, radicou-se em Lisboa. José Bonifácio ingressou como sócio da Academia das Ciências com vinte e seis anos de idade. Pouco tempo depois, com a idade de vinte e sete anos, foi pensionado pelo governo português, por proposta da Academia, para viajar pela Europa, a fim de aperfeiçoar os seus conhecimentos nos ramos da História Natural e Metalurgia. Em Junho de 1790 iniciou, em companhia de outro brasileiro, Manuel Ferreira de Araújo Câmara, e do português Fragoso de Sequeira, um período de estadias nos grandes centros científicos da Europa, que decorreu entre 1790 até 1800. Durante estes anos estagiou em diversos centros universitários em França, Itália, Alemanha, Dinamarca, Holanda, Suécia, Grã-Bretanha, etc. Foi eleito membro das Academias de Estocolmo, Copenhaga, Turim, da Sociedade dos Investigadores da Natureza de Berlim, das de História Natural e Philomatica de Paris, da Geológica de Londres, da Werneniana de Edimburgo, da Mineralógica e da Linneana de Jena, da Philosophica de Filadélfia. Foi ainda membro da Academia Imperial de Medicina do Rio de Janeiro.

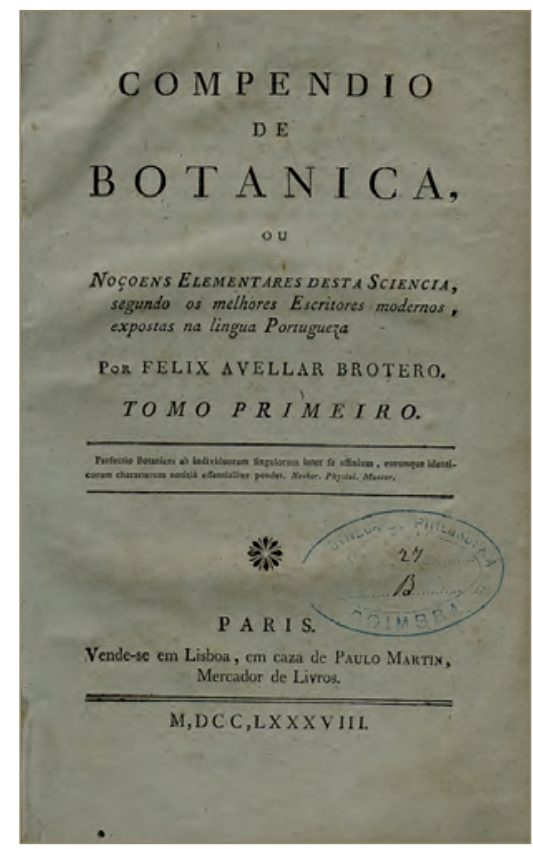

Figura 7 - Compendio de Botanica, ou Noçoens Elementares Desta Sciencia, segundo os melhores Escritores modernos, expostas na lingua Portugueza por Felix Avellar Brotero.

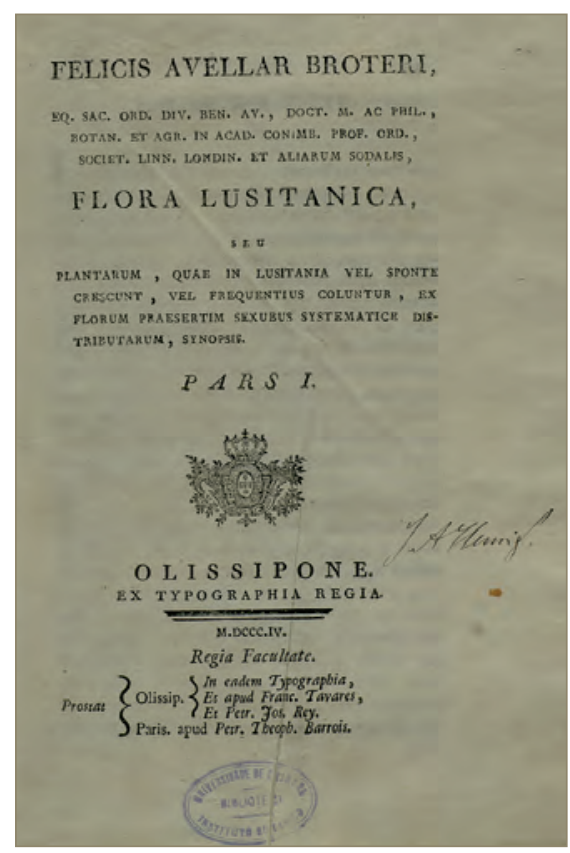

Figura 8 - Flora Lusitanica, seu plantarum, quae in Lusitania vel sponte crescunt, vel frequentius coluntur, ex florum praesertim sexubus systematice distributarum, synopsis/Felicis Avellar Broteri. - Olissipone: Ex Typographia Regia, 1804.

Após dez anos de intensa actividade científica por toda a Europa, José Bonifácio regressou a Portugal no ano de 1800 . Voltando a Coimbra ingressou na carreira académica. Na Congregação da Faculdade de Philosophia de 15 de Maio de 1801 foi lido o seguinte Decreto de 15 de Abril desse ano: 
Que atendendo a $\widetilde{q}$ a cadeira de Metalurgia, $\widetilde{q}$ fui servido crear, tendo por objecto materias muito uteis e interessantes aos meus Reinos e Senhorios, naó pode ser dignam. ' desempenhada, e nem estabelecida, se naõ for por um Filozofo, que tenha viajado pelos paizes, em $\widetilde{q}$ esta sciencia pricipalm. ${ }^{e}$ se cultiva, observando a natureza em grande, e estudando todas as praticas, $\widetilde{q}$ lhe são relativas: axandose plenam. informado de $\widetilde{q}$ as referidas circunstaciaz concorrem na pessoa de José Bonifácio de Andrada, $\widetilde{q}$ para este fim viajou, como pensionario meu de dés anos com conhecido aproveitamento: Ei por bem fazerlhe mercê da referida cadeira, nomeandoo quinto Lente da Faculd.e, e ordenando $\widetilde{q}$ se lhe confira gratuitam.e o grao de Doutor na mesma Faculd. ${ }^{e}$, e em atensao aos penozos trabalhos das viagens $\widetilde{q}$ fés continuados pelo longo espaso dos referidos anos a fim de mais e melhor se abilitar $p^{a}$ o meu Real Serviso, receberá do cofre da Universid. alem do ordenado quinhentos mil reiz cada ano, aqual ficará conservando com a do mesmo ordenado, quando estabelecido e firmado convenientem. ${ }^{\text {o }}$ ensino da referida cadeira, Eu for servido jubila lo nela.

Entre 1807 e 1820 desempenhou o cargo de Superintendente do Rio Mondego e Obras Publicas da Cidade de Coimbra com a missão de executar um programa promovido pelo governo mariano que visava aproveitar o potencial natural do Reino com vistas à sua modernização. Paralelamente à sua actividade docente desempenhou o cargo de Intendente Geral de Minas e Metais do Reino. Foi também Administrador das minas de carvão de Buarcos e de S. Pedro da Cova e das Reais Ferrarias da Foz de Alge, situadas num afluente do Rio Zêzere. Exerceu o cargo de Director do Laboratório de Docimasia da Casa da Moeda em Lisboa, onde se determinava a proporção em que os metais estavam contidos nos minérios. Foi ainda da sua responsabilidade a criação de um laboratório destinado ao apoio de prospectores mineiros em Portugal e no Brasil.

O seu nome, juntamente com o dos químicos suecos Jöns Jakob Berzelius e Johan August Arfwedson, e ainda o do francês Claude Louis Berthollet, está associado à descoberta do elemento químico lítio, o terceiro da Tabela Periódica, depois do hidrogénio e do hélio. Com efeito, foi a partir dos trabalhos publicados por estes químicos que em 1818 outro grande químico, Humphry Davy, em Inglaterra, aplicou a recém-descoberta técnica da electrólise para isolar o novo elemento, a que deu o nome de lítio, do grego lithos (pedra). Andrada e Silva anunciou a descoberta de 12 novos minerais, quatro novas espécies e oito variedades de espécies conhecidas num artigo da revista alemã Allgemeines Journal der Chemie, publicada em 1800 em Leipzig, Entre os minerais descritos estavam a petalita e o espoduménio, que são aluminossilicatos de lítio. $\mathrm{O}$ artigo tinha por título (traduzido para português): Exposição sucinta das características $e$ das propriedades de vários minerais novos da Suécia e da Noruega, com algumas observaçôes químicas sobre os mesmos. A importância deste trabalho justificou a sua publicação em inglês no Journal of Natural Phylosophy, Chemistry and the Arts (1801) e em francês no Journal de Physique, de Chimie, d'Histoire Naturelle et des Arts (1800). Hoje em dia uma Galeria de Minerais, cuja origem remonta à época pombalina, no Departamento de Ciências da Terra da Universidade de Coimbra tem o nome de Andrada e Silva.

Foram vários os professores da Faculdade de Philosophia que ao longo da sua carreira conquistaram um lugar de destaque no meio cultural português no período compreendido entre 1772 e 1836 . Para alguns deles a notoriedade foi para além do empenho dedicado ao ensino e ao desenvolvimento das ciências. Para o serviço docente do Curso de Philosophia, a Faculdade dispunha de cinco Lentes Proprietários, quatro Lentes Substitutos, cinco Demonstradores e os Doutores Opositores da Faculdade. 
Um dos nomes de maior destaque na actividade pedagógica e científica nas primeiras décadas do século XIX foi Manoel José Barjona. Este professor graduou-se a 3 de Outubro de 1786, sendo pouco depois nomeado Lente Substituto. Anos depois viria a ser promovido a Lente Proprietário da cadeira de Zoologia e Mineralogia. Pela carta régia de 15 de Abril de 1801, quando era ainda Substituto foi igualado em graduação e ordenado ao $5 .^{\circ}$ Lente da Faculdade de Philosophia. Na sua actividade científica, Barjona distinguiu-se pelos seus estudos relativos à composição da água, numa época em que também Watt a Cavendish realizavam as suas primeiras experiências neste domínio. Foi durante as experiências de síntese da água, realizadas conjuntamente com Thomé Rodrigues Sobral, que Barjona foi vítima de uma violenta explosão do gasómetro, tendo ficado cego de um olho.

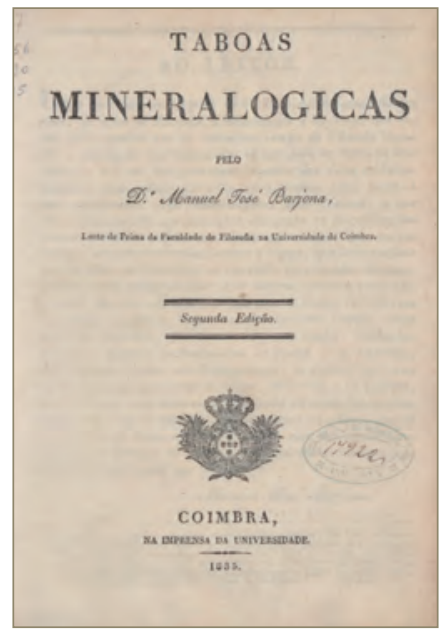

Figura 9 - Taboas mineralogicas de Manoel José Barjona. - 2a ed. - Coimbra: Imp. da Universidade, 1835.

Contribuindo para o desenvolvimento do ensino das ciências, Manoel Barjona foi sempre um activo membro das Congregações da Faculdade. No dia 14 de Março de 1823 submeteu à aprovação do Conselho da Faculdade as suas Taboas Mineralogicas. Este trabalho viria a ter uma segunda edição em 1835. Para além desta obra, já havia publicado em 1798 um compêndio intitulado Metallurgica Elementa, que amplissimi Philosophici Ordinis jussu ad usum academiciem elucubravit. Pela publicação deste compêndio foi contemplado com uma pensão vitalícia de 50\$000 réis. Em 1827 solicitou outra pensão vitalícia de $50 \$ 000$ réis pela publicação das Taboas Mineralogicas (Fig. 9). Este requerimento foi satisfeito apenas parcialmente. Neste ano era ministro do reino o bispo de Viseu, D. Francisco Alexandre Lobo, que rubricou a carta régia de 24 de Abril onde, em nome da infanta regente, D. Isabel Maria, se afirmava o seguinte:

... considerando o apuro em que estavam as rendas da Universidade, e tambem que esta obra não era propriamente um compendio, posto que muito digna de louvor, e que o suplicante já por um compendio recebia $50 \$ 000$ réis, não podia darlhe a pensão que pedia agora; no entanto, atendendo às circumstancias que no dr. Barjona concorriam, e por desejar animar os seus trabalhos, lhe fazia mercê da pensäo annual de trinta mil réis, cedendo o supplicante as ditas Taboas na fórma que propunha. 
Em 1828 Manoel Barjona foi demitido por motivos políticos. O facto de defender as ideias liberais foi a origem de um fim de vida bastante dramático. Foi processado pelo governo absoluto, valendo-lhe nalgumas circunstâncias a influência e protecção de um miguelista, seu antigo discípulo e amigo, o qual evitou que o seu julgamento se realizasse no Porto. Foi julgado em Coimbra, e não havendo provas suficientes que o incriminassem saiu em liberdade condicionada. Não voltou a ser readmitido na Universidade. Até ao fim da sua vida apenas viveu com o rendimento de $80 \$ 000$ réis anuais, correspondentes às pensões relativas às publicações das suas duas obras. Para subsistir teve que vender os seus bens pessoais, contraiu dívidas e valeram-lhe alguns amigos que nunca o abandonaram.

As invasões francesas foram um factor de instabilidade ao normal funcionamento da instituição universitária. Alguns professores da Faculdade de Philosophia prestaram relevantes serviços para a defesa nacional contra os franceses. Em 1808 vários estudantes da Academia de Coimbra alistaram-se num batalhão sob o comando de Tristão Álvares da Costa, lente de Cálculo e major de engenharia. Por sua vez, os lentes formaram outra secção, capitaneada por Fernando Saraiva Fragoso de Vasconcellos, primeiro lente da Faculdade de Cânones. O Vice-Reitor, Manuel Paes de Aragão Trigoso, tinha sido chamado para o cargo de Governador Geral da cidade.

A História do Laboratório Chimico de Coimbra também é rica em episódios em que esteve ao serviço da defesa da nação contra os exércitos de Napoleão e da saúde pública. A Nota sobre os trabalhos em grande que no Laboratório de Chimico da Universidade poderáó praticar..., publicado em 1816 no Jornal de Coimbra, da autoria de Rodrigues Sobral é bem esclarecedora do drama vivido, mais particularmente por aqueles que na Universidade de Coimbra eram mais ciosos da defesa nacional contra os agressores. A azáfama no Laboratório Chimico foi grande, com Sobral assumindo de forma eficiente a coordenação de todo o processo de fabrico de munições, como se demonstra numa transcrição de um texto de 1820, da autoria de José Accursio das Neves, intitulado Memorias sobre os meios de melhorar a Indústria portuguesa, considerada nos seus diferentes ramos. Pela sua descrição ficamos a saber que o Laboratório Chimico se havia transformado como se fosse uma verdadeira unidade de fabrico de muniçôes para os militares portugueses. Pelo papel desempenhado na coordenação dos trabalhos, Rodrigues Sobral viria a ser conhecido como o mestre da pólvora. Este professor não só dirigia e organizava todo o grupo de trabalho no Laboratório Chymico, como também preparava com as suas próprias mãos as munições de guerra. Foram fabricadas espoletas tanto de peça como de granada, estopins, velas de mixto, murrôes, etc. Relatos da época referem que até ao dia 29 de Julho de 1808 fabricaram-se no laboratório mais de 40 arrobas de pólvora. Desde esse dia até 28 de Agosto foram fabricadas mais 23 arrobas e meia. Nos primeiros seis dias deste mês foram preparados 45.260 cartuchos. Para a frente de combate foram enviadas de uma só vez 1.541 espoletas de peça, 650 estopins, 276 espoletas de granada e 100 velas de composição. Foi neste período que todo o arsenal armazenado no edifício do Laboratório Chymico esteve na eminência de explodir. Ao deflagrar um incêndio, com o edifício repleto de barris de pólvora, valeu a serenidade de Thomé Rodrigues Sobral, que conseguiu evitar a catástrofe, utilizando água de uma cisterna próxima. Como consequência do seu empenhamento na luta contra os invasores, aquele professor viu a sua casa destruída pelo incêndio provocado pelos franceses. Neste incêndio ficaram irremediavelmente perdidos todos os preciosos manuscritos, bem como a excelente biblioteca 
que possuía, reunida ao longo de trinta anos. Entre os manuscritos destruídos perdeu-se o seu Compêndio de Chymica. Quando o exército francês chegou a Coimbra, uma das primeiras preocupações dos comandos militares foi o de saberem onde ficava a casa do mestre da pólvora, cognome atribuído pelos invasores ao professor de Química. O resultado foi o bárbaro incêndio das casas da Quinta da Cheira, pertencentes a Rodrigues Sobral. Reconhecendo o seu elevado empenho, o governo, por aviso régio de 31 de Outubro de 1816, mandou reedificar as suas casas.

A guerra trouxe consigo as consequências nefastas para a saúde pública. Também aqui o Laboratório Chimico teve um desempenho assinalável. Decorria o mês de Agosto de 1809, quando Portugal assolado pelo flagelo da guerra se viu a braços com a peste que vitimou a população de todas as freguesias de Coimbra e que se alastrou a vastas regióes do país. Foi neste contexto que Rodrigues Sobral teve uma intervenção como cientista dedicação à causa da saúde pública. As operações desencadeadas sob sua orientação para controlar os efeitos do contágio generalizado foram objecto de merecido reconhecimento público, tendo sido merecedores de pormenorizados relatos diários no periódico Minerva de Coimbra e no Jornal de Coimbra. Nos diários das operações o professor de Química, para além de descrever a intervenção do Laboratório Chimico relatava os pormenores de intervenção em vários locais da cidade de Coimbra. Para erradicar a epidemia foram utilizados desinfectadores de cloro, ácido muriático oxigenado utilizados para purificação da atmosfera. No Laboratório Chymico fabricaram-se desinfectadores, que eram gratuitamente distribuídos pelas casas particulares, pelos hospitais, pelas cadeias e até pelas ruas.

A influência de Thomé Rodrigues Sobral na Universidade de Coimbra estendeu-se até ao ano da sua morte, em Setembro de 1829. No ano anterior, mais propriamente em 24 de Maio de 1828, foi nomeado Vice-Reitor, cargo que, contudo não viria a ocupar por motivos de saúde. Em 1816, publicou no vol. IX, Parte I do Jornal de Coimbra a Nota sobre os trabalhos em grande que no Laboratório de Quimica se poderiam praticar. Este artigo mereceu um comentário elogioso por parte de um leitor anónimo, do Porto, que se identificava apenas pelas iniciais A.P. no qual expressava o desejo de que se dessem bom uso dos conhecimentos e zelo deste experimentado professor, cujos planos certamente nada teriam de imaginário e impostura. Foi bem patente a dedicação com que Sobral sempre lutou pelo desenvolvimento da ciência química em Portugal, empenhado em «tornar o Laboratório Chimico de grande utilidade para a Nação: de interesse para a Universidade; de crédito e consideração paras as outras Nações», um laboratório destinado não só ao ensino público dos Elementos da ciência química, mas também à prática da química aplicada.

\section{O Gabinete de Física Experimental}

No Gabinete de Física Experimental, António Dalla Bella, oriundo de Pádua, veio para Portugal para organizar o ensino daquela disciplina no Colégio dos Nobres de Lisboa. Em 1772 foi transferido para Coimbra. Deixou de ensinar no ano escolar de 1785-1786, sendo substituído no serviço docente por Teotónio Brandão, Ribeiro de Paiva e Constantino Botelho de Lacerda. Durante cerca de quatro décadas o ensino da Física Experimental esteve a cargo de Botelho de Lacerda, que nasceu em Março de 
1754, em Murça, e faleceu entre 1820 e 1822. Foi Doutor e Lente de Philosophia na Universidade de Coimbra, sócio da Real Academia das Ciências de Lisboa. Tinha 18 anos, em 1772, quando se matriculou em Philosophia na Universidade de Coimbra. Mostrando assídua aplicação e elevada inteligência foi, por aviso régio de 23 de Janeiro de 1778, graduado gratuitamente. No dia 24 de Janeiro de 1791 Constantino António Botelho de Lacerda foi nomeado Lente Proprietário de Física Experimental, tendo falecido sem ter chegado a jubilar-se. O seu ensino da Física Experimental granjeou-lhe uma grande reputação. No dia 9 de Julho de 1791, Botelho de Lacerda foi encarregado, pelo Conselho da Faculdade de Philosophia, de uma versão em latim da obra Exposition raisonnée de la Theorie de l'electricité et du magnetisme d'après les principes de M. Aepinus, por M. l' Abbé Haüy. No dia 14 de Janeiro de 1807 a Congregação da Faculdade de Philosophia reuniu na sala do Gabinete de Física, resultando, para além de outras, a seguinte deliberação: 3. ${ }^{\circ}$ que para o augmento do Gabinete de Physica se mandem modelar algumas Machinas, que importantemente são empregadas nos usos das Artes. Se, por um lado, Botelho de Lacerda se empenhou profundamente para o desenvolvimento do ensino da Física Experimental em Coimbra, também é verdade que este professor presenciou uma das páginas mais tristes da história do Gabinete. Durante a sua direcção o Gabinete sofreu uma perda que o tempo não conseguiu reparar. Por ocasião da ocupação francesa, o exército de Massena entrou em Coimbra no dia 30 de Setembro de 1810 e no dia 2 de Outubro foram levados pelos invasores, um óculo astronómico, um óculo de Galileu e dois magníficos microscópios que tinham sido comprados em Inglaterra. Para além da sua dedicação ao ensino da Física, foi também muito competente em assuntos de agricultura, e deixou várias memórias no Investigador Portuguez, Jornal de Coimbra e nas Memorias da Academia das Sciencias. Tornou-se principalmente notável por ter descoberto um novo modo de aplicar a força do vapor ao movimento das máquinas. A memória sobre este invento foi lida na sessão pública da Academia de 18 de Janeiro de 1805, e no último parágrafo queixava-se de que a glória da sua invenção lhe fosse roubada por Verzy, o qual arrogando a si a descoberta, a propusera ao ministro do interior em França, e obtivera os fundos indispensáveis para fazer experiências em ponto grande. Sobre a descoberta de Constantino Botelho deve ler-se a Historia Resumida da Invenção e Melhoramentos da Machina a Vapor, do visconde de Villarinho de S. Romão. A descrição da máquina vem no jornal de Coimbra, de Abril de 1812, acompanhada de estampas. Não consta que Constantino Botelho imprimisse em separado alguns dos seus trabalhos. As muitas Memórias que escreveu foram publicadas em vários jornais da época, e noutras colecçôes científicas.

A Botelho de Lacerda sucedeu-se na direcção do Gabinete de Física Experimental o professor José Homem de Figueiredo Freire, que foi autor do Catálogo dos instrumentos com que tem sido aumentado o Gabinete de Physica da Universidade desde o ano de 1772 até ao presente de 1824. Este catálogo testemunha uma forte dinâmica de actualização do Gabinete de Física, concretizada pela aquisição continuada de equipamento didáctico moderno.

No ano de 1812 fazia parte do corpo docente José Homem de Figueiredo Freire, na qualidade de Doutor Opositor, vindo a ser o sucessor de Botelho de Lacerda na direcção do Gabinete de Física Experimental. José Homem de Figueiredo Freire foi Doutor em Philosophia e Lente da Universidade de Coimbra. Nasceu em S. Pedro do Sul, e faleceu na Figueira da Foz em Setembro de 1837 estando em uso de banhos. Dou- 
torouse em 31 de Julho de 1807. Regeu várias cadeiras, permanecendo até à sua morte na de Physica Experimental. Deixou importantes manuscritos em poder da sua viúva, a quem foram pedidos por alguns membros da Faculdade. Em Congregação de 13 de Abril de 1842 dois vogais declararam que tinham conservado em seu poder os manuscritos de Botânica e de Física de José Homem de Figueiredo Freire, mas que iam restituí-los à viúva. Além dos manuscritos, publicou as seguintes obras: Catalogo das plantas naturaes e exoticas, que se encontram em S. Pedro do Sul; Monographia das plantas cryptogamicas; Methodo pratico de trabalhar com as machinas de Physica. Durante a gestão de José Homem de Figueiredo Freire, o Gabinete de Física Experimental continuou a ver engrandecida a sua colecção de instrumentos científicos e didácticos, procurando, desta forma, acompanhar o ritmo de desenvolvimento quer sob o ponto de vista pedagógico, quer científico, que então se observava na Europa. Um numeroso conjunto de instrumentos tornou mais rica a colecção do Gabinete. Assim, no dia 1 de Agosto de 1827, foram aprovadas várias requisições dos diversos estabelecimentos da Faculdade de Philosophia, tendo sido o Gabinete de Física contemplado com um notável número de modernos aparelhos.

\section{As Reformas de 1836 e 1844}

Em consequência da invasão francesa só no ano lectivo de 1811 - 1812 o ensino retomou a normalidade. Neste ano o curso da Faculdade de Philosophia constava de quatro anos de estudo efectivo, nos quais se ensinava a Zoologia, a Mineralogia, a Química, a Metalurgia e a Física Experimental, estando estes estudos distribuídos por cinco cadeiras. No primeiro ano ensinava-se Zoologia e Mineralogia, estando o segundo ano do curso destinado ao ensino da Física Experimental. Numa passagem do artigo intitulado Breve notícia da Faculdade de Philosophia da Universidade de Coimbra, publicado no Jornal de Coimbra, afirmava-se que a Física era uma ciência que fazia conhecer pela experiência as propriedades, equilíbrio e movimento dos corpos. O seu método consistia primeiramente em coligir factos averiguados pela observação e experiência, chegando depois, pela combinação e generalização a um facto primordial, que permitisse explicar sinteticamente os factos particulares. Neste artigo o autor afirmava que a Física era considerada uma ciência histórica, racional e experimental. As propriedades dos corpos podiam ser consideradas em abstracto, ou em concreto; por isso deveria dividir-se a Física em geral e particular. A Física geral tinha por objecto a Mecânica, ciência do equilíbrio e movimento dos corpos. Sendo estes sólidos ou fluidos dividia-se a Mecânica em Estática, ou equilíbrio dos sólidos; em Dinâmica, ou movimento dos sólidos; em Hidrostática, ou equilíbrio dos fluidos, e em Hidrodinâmica, ou movimento dos fluídos. A Física particular ocupava-se do exame das propriedades de certos corpos, como a água, o ar, o fogo, a luz, e os fluidos magnético, eléctrico e galvânico.

O terceiro ano do Curso Philosofico era constituído por duas cadeiras. Numa ensinava-se Botânica e Agricultura, enquanto na outra o objecto de ensino era a Química Teórica. O quarto ano era destinado à frequência da cadeira de Metalurgia, onde se tratava da extracção dos metais das suas respectivas minas. Este estudo iniciava-se pela Docimasia, que consistia no ensaio experimental de produtos provenientes das 
minas, determinação exacta da sua constituição e da proporção das substâncias que os compunham, tendo como finalidade o conhecimento da sua qualidade e quantidade. Depois deste exame, iniciavam-se os trabalhos de sondagem dos terrenos, a abertura de poços, reconhecimento dos veios metálicos, estabelecimento e sustentação de galerias, esgotamento de águas das minas, defesa dos trabalhadores da acção dos gases nocivos à vida, extracção, lavagem, etc..

Os estudantes que pretendiam fazer a formatura, bem como os que somente queriam obter o bacharelato, eram obrigados a frequentar os quatro anos do curso. O acto do quarto ano conferia o grau de Bacharel. Para a obtenção da Formatura os estudantes frequentavam um novo ano onde tiravam ponto nos quatro anos. Os que pretendiam ser Licenciados ou Doutores deveriam frequentar mais um ano, no qual ouviam as lições do terceiro e do quarto ano.

Depois de um longo período entre 1828 até 1834 , no qual a Universidade teve um funcionamento irregular, tendo mesmo sido encerrada, retomou a sua actividade normal durante o governo de Passos Manuel. Os rápidos e incessantes progressos das ciências naturais observados no início do século XIX tornavam cada vez mais urgente uma nova organização do Curso Philosophico, e o decreto de 5 de Dezembro de 1836 aprovou e mandou pôr em execução o novo plano de estudos, proposto ao governo por José Alexandre de Campos, Vice-Reitor da Universidade. Na realidade, era urgentíssima uma reforma que ampliasse e melhorasse o ensino, com o fim de o harmonizar com o estado de perfeição a que já tinham chegado os principais ramos da Philosophia Natural nos países mais cultos. A antiga organização curricular ordenada pelos Estatutos de 1772, à qual tinham sido introduzidas pequenas reformas, começava a revelar-se inadequada, considerando o nível de desenvolvimento que caracterizava a ciência nos primeiros trinta anos do século XIX. As fronteiras da ciência eram muito mais amplas do que na época pombalina. O ritmo do desenvolvimento científico permitiu uma maior diversidade e aperfeiçoamento dos meios de observação e de investigação dos fenómenos da natureza. Os estudos philosophicos tornaram-se significativamente mais abrangentes no domínio das novas teorias científicas e aplicaçoes tecnológicas. Consequentemente era impossível manter por mais tempo o plano primitivo da Faculdade. Com a reforma de 1836 o Curso de Filosofia Natural ficou divido em cinco anos, constituindo a Mineralogia e Zoologia duas cadeiras independentes. Foram criados os cursos especiais de Agricultura, Economia Rural e Tecnologia. Este plano de estudos tornava ainda obrigatória a frequência de quatro cadeiras de Matemática e uma de Medicina.

A reforma de 1836, no entanto, muito cedo se revelou pouco profunda relativamente às expectativas de desenvolvimento do ensino teórico e prático nas diversas áreas científicas na Faculdade de Philosophia. Assim, os estudos de Química eram feitos sem serem precedidos pelas noções gerais de Física, reflectindo-se este facto no aproveitamento dos alunos. Os anos que se seguiram demonstraram ser indispensável uma boa formação em Física para que os estudos de Química fossem realizados com sucesso. Por outro lado, a opção feita tinha resultado da necessidade de se fazer anteceder os estudos de Física por uma conveniente preparação em Matemática. Começou a ser um sentimento generalizado a grande necessidade de ampliação dos estudos, criando para isso novas cadeiras de estudos especializados que permitissem dar uma formação condigna com o desenvolvimento científico e tecnológico observado nos países mais desenvolvidos da Europa. Por várias vezes 
foi apresentada a proposta de desdobramento do ensino da Física Experimental, sem que, contudo, este intento tivesse sido conseguido antes do final da década de cinquenta. Com efeito, foi apenas por volta de 1860 que começou a ganhar forma definitiva um plano de estudos no qual o ensino da Física Experimental ficou distribuído por duas cadeiras anuais.

As sucessivas reformas introduzidas no Curso Philosophico sempre tiveram correspondência no Curso Mathematico, por forma a manter uma perfeita harmonia na formação científica dos estudantes que frequentavam cadeiras nas duas Faculdades. Pela carta régia de 1 de Abril de 1801 foram criadas na Faculdade de Mathematica as cadeiras de Astronomia Prática e de Hidráulica. Na primeira cadeira foi provido António José de Araújo Sancta Barbara, passando para a de Astronomia Teórica Manuel Joaquim Coelho da Costa Vasconcellos e Maia, na qual se ensinava a Mecânica Celeste de Laplace. Considerando indispensável a existência de uma bibliografia sobre os assuntos de Análise Matemática e Mecânica, que fosse adequado ao estudo aprofundado das leis celestes, bem como das suas aplicações, Vasconcellos e Maia procurou organizar o programa da sua cadeira tendo em consideração não somente os trabalhos originais de Laplace, mas também recorrendo aos trabalhos dos mais ilustres geómetras do século XVIII, que se achavam dispersos por muitas e diversas obras e memórias de diferentes sociedades científicas. Na cadeira de Hydraulica foi provido Manuel Pedro de Mello. Para que o ensino nesta cadeira atingisse um nível científico digno de mérito, este professor foi incumbido pelo governo de uma viagem científica a França, Holanda, Bélgica e Itália, para se especializar nas aplicaçóes práticas de Hidráulica, estudos então pouco desenvolvidos em Portugal. A cadeira de Hydraulica somente foi definitivamente aberta após o seu regresso, que só teve lugar em 1815 .

Pelo decreto de 5 de Dezembro de 1836, deu-se uma nova organização aos estudos científicos da Faculdade de Mathematica. O Curso das Sciencias Mathematicas foi elevado a cinco anos, determinandose que no $3 .^{\circ}$ ano se estudasse somente a Mecânica dos Sólidos, Óptica e Acústica; no 4. ${ }^{\circ}$ ano Mecânica dos Fluidos e Arquitectura Hidráulica na 4..$^{a}$ cadeira, e na 5. ${ }^{a}$ Astronomia Elementar e Prática; e, finalmente, no 5. ${ }^{\circ}$ ano Mecânica Celeste na 6..$^{a}$ cadeira, e na 7. a Arquitetura Civil, Militar e Subterrânea e Artilharia. Os preparativos de Philosophia exigidos para o Curso Mathematico foram os de Química, Física Experimental, Mineralogia, Geodesia e Metalurgia, devendo ser estudados sucessivamente, e nesta ordem, nos três primeiros anos do curso. Determinou-se que os repetentes de Mathematica frequentassem a cadeira de Cálculo, e na Faculdade de Philosophia a Física Experimental. Os estudantes ficavam isentos de formar teses em Matemáticas Puras. O Curso de Mathematica foi considerado habilitação suficiente para os cargos e ofícios em que fosse requerida a carta de engenheiro civil ou militar, assim como para os postos das diferentes armas do exército e da armada, e bem assim para todos os ofícios ou empregos da Fazenda, devendo ser, em igualdade de circunstâncias, preferidos aqueles que juntassem carta de formatura nesta ciência.

O sentimento de que alguns aspectos importantes para o ensino teórico e prático da Física não tinham sido contemplados nas reformas anteriores, e a necessidade de se promover uma alteração do organograma geral do ensino, levaram as comissōes das Faculdades de Mathematica e de Philosophia a elaborar em 1844 uma nova proposta de reformas da legislação académica consideradas indispensáveis. Um avanço impor- 
tante, mas que apenas parcialmente satisfez as solicitações do corpo docente, foi o do alargamento do ensino da Física. Com efeito, para além de uma cadeira anual de Physica Experimental, frequentada no terceiro ano, foi introduzida uma nova cadeira que na primeira metade do ano lectivo era dedicada ao estudo dos princípios fundamentais da Física, seguindo-se o estudo da Química Inorgânica. Era o seguinte o quadro curricular na Faculdade de Philosophia:

\begin{tabular}{c|c|l}
\hline \multicolumn{3}{c}{ Organização curricular da Faculdade de Philosophia em 1844} \\
\hline Ano & Cadeira & \\
\hline $1 .^{\circ}$ & $1 .^{\mathrm{a}}$ & Introdução à História Natural dos três reinos \\
$2 .^{\circ}$ & $2 .^{\mathrm{a}}$ & Principios de Physica; Chymica inorganica \\
$3 .^{\circ}$ & $3 .^{\mathrm{a}}$ & Physica Experimental \\
& $4 .^{\mathrm{a}}$ & Chymica organica; Analise e Philosophia Chymica \\
$4 .^{\circ}$ & $5 \mathrm{a}^{\mathrm{a}}$ & Anatomia e Physiologia comparada; Zoologia \\
$5 .^{\circ}$ & $6 .^{\mathrm{a}}$ & Anatomia e Physiologia Vegetais; Botanica \\
& $7 .^{\mathrm{a}}$ & Mineralogia, Geologia, Arte de Minas e Metalurgia \\
\hline.$^{\mathrm{a}}$ & Agricultura, Economia Rural e Technologia \\
\hline
\end{tabular}

Para além destas cadeiras, os alunos frequentavam também, no primeiro ano, a $1 .^{\mathrm{a}}$ cadeira da Faculdade de Mathematica, cujo conteúdo programático era: Aritmética, Geometria Sintética, Álgebra e Trigonometria Plana. No segundo ano frequentavam a 2. ${ }^{\text {a }}$ cadeira do segundo ano de Matemática, onde continuavam o estudo de Álgebra e estudavam Álgebra Superior, Geometria Analítica, Cálculo Diferencial, Princípios Elementares de Cálculo Integral.

\section{A Reforma de 1861}

Depois da reforma de 1844 a Universidade voltou a passar por um novo período de instabilidade. Durante o ano lectivo de 1846 e 1847 os Cursos das Faculdades de Philosophia e de Mathematica estiveram suspensos. A década de cinquenta do século XIX foi assinalada pelo início de uma intensa actividade da qual resultou uma significativa evolução do Gabinete de Física e no ensino da Física Experimental em Coimbra. Este processo de desenvolvimento culminou com o desdobramento do ensino da Física Experimental em duas cadeiras anuais no Curso de Philosophia. No início da segunda metade do século, a experiência adquirida nos poucos anos decorridos desde a reforma de 1844 tinha demonstrado que não era possível, por falta de tempo, leccionar com a qualidade desejada alguns dos ramos das ciências físico-matemáticas e dar a outros o desenvolvimento que a evolução dos conhecimentos teóricos e técnicas experimentais exigiam. 
Em 6 de Junho de 1851 foi aprovado pela Congregação da Faculdade de Philosophia um plano de estudos, no qual o Curso Philosophico ficava dividido em três partes. Após a formação fundamental, o curso dividia-se em estudos de Ciências Naturais, cujas cadeiras deveriam ser frequentadas no quarto ano. O quinto ano destinava-se ao estudo das ciências aplicadas. Um dos aspectos mais relevantes desta proposta de reformulação curricular foi a introdução de uma segunda cadeira anual de Física Experimental, reafirmando um desejo já antigo dos docentes da Faculdade. Era a seguinte a estrutura proposta:

\begin{tabular}{|c|c|c|}
\hline $1 .^{\circ}$ ano & $\begin{array}{l}\text { 1. a cadeira }-1 .{ }^{a} \text { cadeira de physica. } \\
1 .^{\circ} \text { ano mathematico. }\end{array}$ & $\begin{array}{l}\text { propriedades gerais dos corpos nos seus diferentes es- } \\
\text { tados, calorico, electricidade estatica, galvanismo, } \\
\text { phenomenos electrodynamicos e thermoelectricos. }\end{array}$ \\
\hline $2 .^{\circ}$ ano & $\begin{array}{l}\text { 2. }{ }^{a} \text { cadeira - chimica inorganica. } \\
\text { 2. }{ }^{\circ} \text { ano mathematico. }\end{array}$ & \\
\hline $3 .^{\circ}$ ano & $\begin{array}{l}\text { 3. }{ }^{\mathrm{a}} \text { cadeira }-2 .^{a} \text { cadeira de physica. } \\
4 .^{\mathrm{a}} \text { cadeira - chimica organica, } \\
\text { analyse e philosophia chimica. }\end{array}$ & mechanica, acustica, optica e magnetismo. \\
\hline
\end{tabular}

\section{CURSO DE SCIENCIAS NATURAES}

\begin{tabular}{l|l}
$4 .^{\circ}$ ano & $\begin{array}{l}\text { 5. } \text { cadeira mineralogia. } \\
6 .^{\text {a }} \text { cadeira zoologia. } \\
\text { 7. }{ }^{\text {a }} \text { cadeira botanica. }\end{array}$
\end{tabular}

\section{CURSO DE SCIENCIAS APLICADAS}

\begin{tabular}{|c|c|}
\hline $5 .^{\circ}$ ano & $\begin{array}{l}\text { 8. a cadeira agricultura, economia rural e veterinaria. } \\
9 .^{\text {a }} \text { cadeira techonologia. } \\
10 .^{\text {a }} \text { cadeira mettalurgia e docimasia. }\end{array}$ \\
\hline
\end{tabular}

Apesar da insistência do Conselho da Faculdade, o governo não aprovou este plano de estudos e apenas em 1861 o Curso Philosophico passou a dispor de duas cadeiras anuais de Física. Foram várias as propostas apresentadas ao governo, tendentes a introduzir reformas curriculares que tornassem o ensino mais actualizado. Em 22 de Junho de 1855 foi presente um ofício do Conselho Superior de Instrução Pública, pedindo o voto da Faculdade acerca da reforma dos estudos Philosophicos, proposto ao governo em consulta de 11 de Abril de 1851. Para responder a este ofício foi nomeada uma comissão que apresentou o seu parecer em Congregação de 21 de Julho. Numa passagem deste parecer podemos ler o seguinte:

Quando por toda a parte os povos dirigem as suas vistas para os melhoramentos materiais, quando todas as naçôes do mundo civilisado estão dando a máxima importância ao estudo das ciências philosophicas, como fonte priomodial d'estes melhoramentos, seria com effeito para estranhar que o primeiro estabelecimento scientifico do reino ficasse estacionario no meio d'este movimento geral, e que a Faculdade de Philosophia manifestasse pouco empenho em se elevar à altura do seu glorioso destino... Os rapidos e avantajados progressos, que a Physica tem feito no presente século, não consentem que este ramo se possa estudar, ainda que mui perfunctoriamente 
seja, em um só curso annual. Os tratados do calorico, da luz, da electricidade e do magnetismo são tão avultados, que dariam materia de sobejo para constituirem outras tantas cadeiras especiaes. D'uma tal vastidão de doutrinas ha de necessariamente resultar, como sempre tem acontecido, que os alumnos fiquem ignorando completamente alguns d'elles, a despeito de todos os esforços e diligencias do respectivo professor, que para adiantar o compêndio, se vê as mais das vezes obrigado a explicar toda a hora, com grave prejuizo não só da disciplina, mas também do aproveitamento dos mesmos alumnos.

Também na Faculdade de Mathematica foram apresentadas propostas para o desenvolvimento do ensino teórico de algumas áreas da Física. Fundamentando-se no argumento de que deveriam ser introduzidas novas áreas de ensino teórico e prático que acompanhassem os mais recentes desenvolvimentos científicos, a Congregação da Faculdade decidiu em 27 de Abril de 1857 consultar o governo, pedindo que se introduzisse no organograma curricular mais uma cadeira, dedicada à Geometria Descritiva e se introduzissem novas cadeiras que contemplassem estudos avançados de Acústica e Óptica, que fossem complementados pela parte experimental no Gabinete de Física. Em atenção àquele pedido foi criada, por carta de lei de 26 de Fevereiro de 1861, a cadeira de Geometria Descriptiva, e em portaria de 5 de Março do mesmo ano o governo ordenou que o Conselho apresentasse um programa completo da distribuição das matérias a ensinar pelas oito cadeiras do novo Curso Mathematico. Por sua vez, na reunião do Conselho da Faculdade de Philosophia do dia 29 de Julho de 1858, foi elaborada uma consulta sobre a nova distribuição dos estudos das ciências Physico- Chymicas e Historico-Naturaes na Universidade de Coimbra, submetida à aprovação do governo. Segundo esta proposta o curso passou a ter a seguinte estrutura:

\section{1. ${ }^{\circ} \mathrm{ANO}$}

\begin{tabular}{|l|l|}
\hline 1. ${ }^{\text {c }}$ cadeira & $\begin{array}{l}\text { Physica Elementar }-15 \text { de Outubro até } 31 \text { de Janeiro. } \\
\text { Chimica Inorganica }-1 .^{\circ} \text { de Fevereiro até ao ponto. }\end{array}$ \\
\hline & Geometria e Algebra, na Faculdade de Mathematica. \\
\hline
\end{tabular}

2. ${ }^{\circ} \mathrm{ANO}$

\begin{tabular}{|l|l|}
\hline 2. ${ }^{\text {a cadeira }}$ & $\begin{array}{l}\text { Chimica Organica }-16 \text { de outubro até } 30 \text { de março. } \\
\text { Analyse Chimica }-1 \text { de outubro ate ao ponto. }\end{array}$ \\
\hline & Calculo, na Faculdade de Mathematica. \\
\hline
\end{tabular}

3. $\mathrm{ANO}$

\begin{tabular}{|l|l|}
\hline 3. ${ }^{\text {a }}$ cadeira & Physica Superior. \\
\hline
\end{tabular}

4. ${ }^{\circ} \mathrm{ANO}$

\begin{tabular}{|c|l|}
\hline 4. ${ }^{\text {a }}$ cadeira & $\begin{array}{l}\text { Anatomia e Physiologia Comparadas } \\
\text { Zoologia. }\end{array}$ \\
\hline $5 .^{\text {a }}$ cadeira & $\begin{array}{l}\text { Anatomia e Physiologia Vegetaes } \\
\text { Botanica. }\end{array}$ \\
\hline
\end{tabular}




\begin{tabular}{|c|l|}
\hline 6. ${ }^{\text {a cadeira }}$ & $\begin{array}{l}\text { Mineralogia }-16 \text { de outubro a } 15 \text { de janeiro. } \\
\text { Geologia }-16 \text { de janeiro a } 15 \text { de abril. } \\
\text { Montanistica e Legislação sobre Minas - } 16 \text { de abril até ao ponto. }\end{array}$ \\
\hline $7^{\text {a }}$ cadeira & $\begin{array}{l}\text { Agricultura Geral }-16 \text { de outubro a } 31 \text { de janeiro. } \\
\text { Economia e Legislação Agricola }-1 .^{\circ} \text { de fevereiro até } 15 \text { de abril. } \\
\text { Zootechnia }-16 \text { de abril ate ao ponto. }\end{array}$ \\
\hline
\end{tabular}

6. ${ }^{\circ}$ ANO - Repetição das 3. a e 6. ${ }^{a}$ cadeiras.

Apesar do relativo avanço observado, o plano de estudos aprovado ainda não satisfazia o corpo docente da Faculdade. Os progressos incessantes de todos os ramos da indústria, e as tendências da época exigiam que se desse aos ramos de aplicação um desenvolvimento, que não se coadunava com a organização da Faculdade então em vigor, e mais especificamente com a situação limitativa em que se encontrava o ensino da Física. Apesar do $3 .^{\circ}$ ano ser integralmente destinado ao estudo dos vários ramos de especialidade, considerava-se exíguo o pouco tempo que lhe estava reservado, impedindo que os métodos da Física Experimental fossem ensinados de acordo com o desenvolvimento que até então se tinha observado nesta ciência. Apenas no ano de 1861 foi definitivamente contemplado o desejo de serem integradas duas cadeiras anuais de Física no Curso Philosophico, as quais passaram a ser a $3 .^{\mathrm{a}}$ e a $5 .^{\mathrm{a}}$ cadeiras deste curso, integradas no $3 .^{\circ}$ e $4 .^{\circ}$ ano, respectivamente. A nova estrutura do Curso Philosophico foi aprovada através da portaria do Ministério do Reino, no dia 9 de Outubro de 1861, a qual foi apresentada ao Conselho da Faculdade no dia 17 de Outubro. Com esta importante reforma do Curso Philosophico pretendiase que o quadro curricular ficasse harmonizado com os das Faculdades de Mathematica e Medicina.

Após a reforma de 1861 os professores que mais se distinguiram para o desenvolvimento do ensino da Física Experimental foram Jacinto António de Sousa e António dos Santos Viegas. Em 1861 o curso ficou organizado do seguinte modo:

\begin{tabular}{c|c|l}
\hline \multicolumn{3}{c}{ Organização curricular da Faculdade de Philosophia em 1861} \\
\hline Ano & Cadeira & \\
\hline $1 .^{\circ}$ & $1 .^{\mathrm{a}}$ & Chymica Inorganica e Metallurgia \\
$2 .^{\circ}$ & $2 .^{\mathrm{a}}$ & Chymica Organica, Analyse Chymica \\
$3 .^{\circ}$ & $3 .^{\mathrm{a}}$ & Physica Experimental \\
& $4 .^{\mathrm{a}}$ & Botânica \\
$4 .^{\circ}$ & $5 .^{\mathrm{a}}$ & Physica dos Imponderáveis \\
& $6 .^{\mathrm{a}}$ & Anatomia e Physiologia Comparadas, Zoologia \\
$5 .^{\circ}$ & $7 .^{\mathrm{a}}$ & Mineralogia, Geologia, Montanistica \\
& $8 .^{\mathrm{a}}$ & Agricultura Geral, Zootechnia, Economia Rural \\
$6 .{ }^{\circ}$ & & repetição das 5. ${ }^{a}$ e 7. ${ }^{a}$ cadeiras \\
\hline
\end{tabular}


$\mathrm{Na}$ Faculdade de Mathematica os estudantes de Philosophia estudavam no primeiro ano Álgebra Superior, princípios da teoria dos números; Geometria Analítica a duas e três dimensões, teoria das funções circulares, Trigonometria Esférica. No segundo estudavam Calculo Diferencial e Integral; teoria das probalidades. Nos primeiro quatro anos do curso também frequentavam uma cadeira anual de Desenho. Para além das cadeiras específicas de Matemática, o curso também era constituído por disciplinas onde se estudava Mecânica Racional e as suas aplicações às máquinas, descrição e utilização dos instrumentos ópticos. Também fazia parte da organização do curso uma cadeira de Física Matemática, contemplando no seu programa as aplicações da Mecânica às Construções. $\mathrm{Na}$ área da Astronomia havia uma cadeira de Mecânica Celeste. Também esta reorganização curricular foi feita obedecendo ao princípio da complementaridade da formação académica dos estudantes, através da frequência obrigatória de cadeiras do Curso Philosophico. Além daquelas cadeiras, os estudantes frequentavam no primeiro ano, na Faculdade de Philosophia, a cadeira anual de Chymica Inorganica e Mettalurgia e outra de Desenho. No segundo ano frequentavam a cadeira de Physica Experimental e Desenho e no terceiro a cadeira de Physica dos Imponderáveis. No quarto ano estudavam também Botânica e no quinto, Mineralogia, Geologia e Arte de Minas.

A reforma curricular das Faculdades de Philosophia e de Mathematica, autorizada pelo governo em 1861, apesar de muito significativa, muito cedo mereceu a insatisfação generalizada do seu corpo docente. Na Memória Histórica da Faculdade de Philosophia, Joaquim Augusto Simões de Carvalho comentava que, comparando a organização curricular actual com o quadro que a constituía na sua fundação, verificava-se que em 1872 possuía o dobro das cadeiras, e cada uma delas com um programa vasto e extensamente complexo. Não podia deixar de suceder assim, para não faltar à lei de paralelismo que deveria manter-se entre os progressos das ciências e a contínua modernização dos estabelecimentos encarregados do seu ensino. Era certo, porém, que o quadro actual de disciplinas era ainda muito deficiente e imperfeito, se atendermos ao grande desenvolvimento que no século XIX tiveram todos os ramos da Philosophia Natural.

Para o ensino prático, a Faculdade possuía espaços apropriados que desde a sua fundação se foram adequando ao desenvolvimento da ciência: o Anfiteatro e o Laboratório Chimico (Fig. 9 e Fig. 10), o Museu de Zoologia (Fig. 11); o anfiteatro do Museu de História Natural (Fig. 12), a sala de aula de Geologia (Fig. 13), o Museu Botânico e o Jardim Botânico (Fig. 14 e Fig. 15), Em 1856 foi aprovado o plano para a construção de uma estufa no Jardim Botânico da Universidade de Coimbra, concebida pelo engenheiro Pedro José Pezerat, tem sido executada parte no Instituto Industrial de Lisboa e parte na fábrica da Fundição de Massarelos, no Porto (Fig. 16 e Fig. 17). No ano de 1866 foi contratado em Paris o botânico Edmond Goeze para dirigir o Jardim Botâanico e especialmente as estufas, tendo-as dotado de uma importante variedade de plantas tropicais. Em 1873 Júlio Augusto Henriques foi nomeado Director do Jardim Botânico e criou o Herbário que viria a ser uma referência a nível mundial (Fig. 18). Em 1885 o Museu de História Natural da Universidade passou a estar organizado em quatro secçóes: Zoologia, Botânica, Mineralogia e Anthropologia e Archeologia Prehistorica (Fig. 19), dirigidas pelos professores das disciplinas correspondentes. Foi criada a cadeira de Anthropologia, Paleontologia Humana e Archeologia Prehistórica em substituição da de Agricultura e Economia Rural, tornando-se Bernardino Machado responsável pela respectiva secção. 


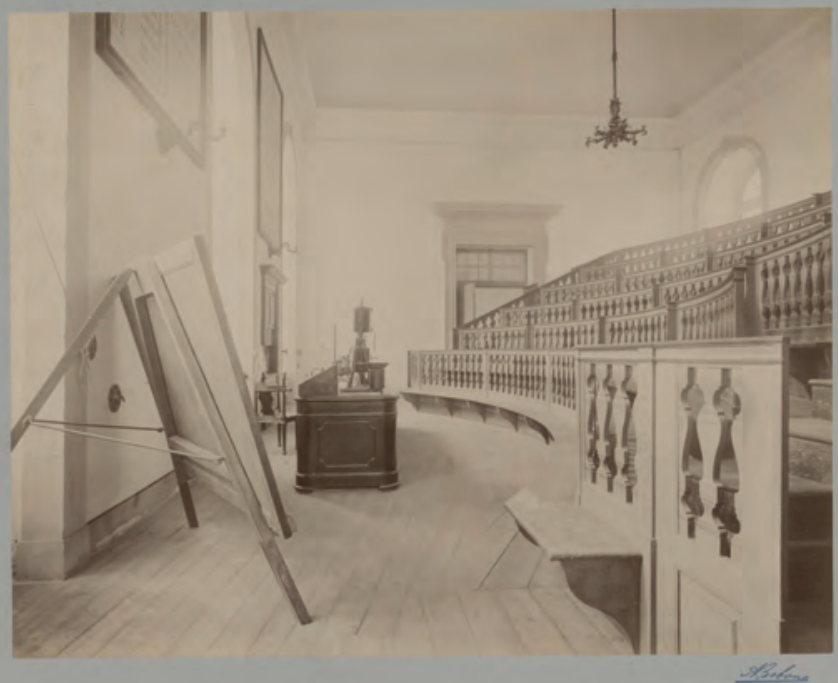

Figura 9 - Anfiteatro do Laboratório Chimico. Fotografia de Augusto Bobone (1902).

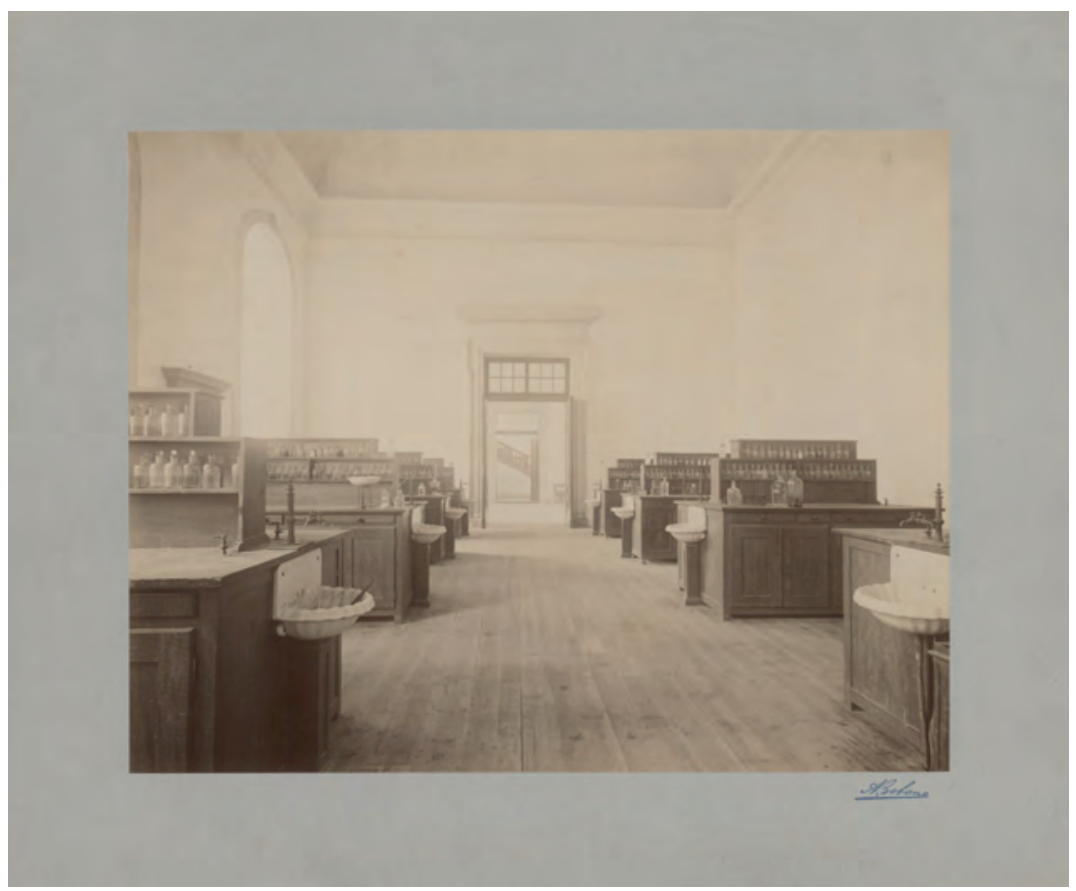

Figura 10 - Laboratório Chimico. Fotografia de Augusto Bobone (1902). 


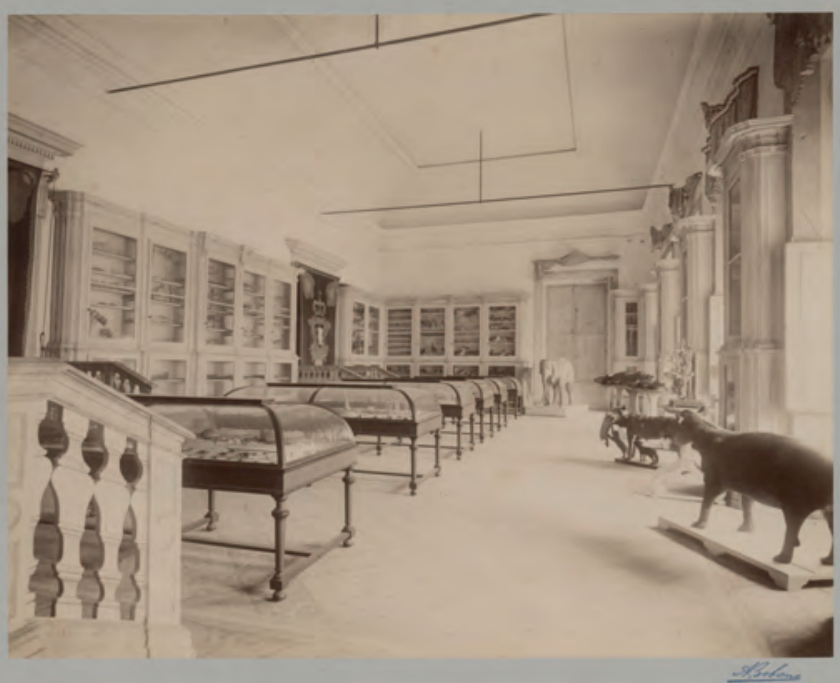

Figura 11 - Museu de Zoologia. Fotografia de Augusto Bobone (ca. 1893).

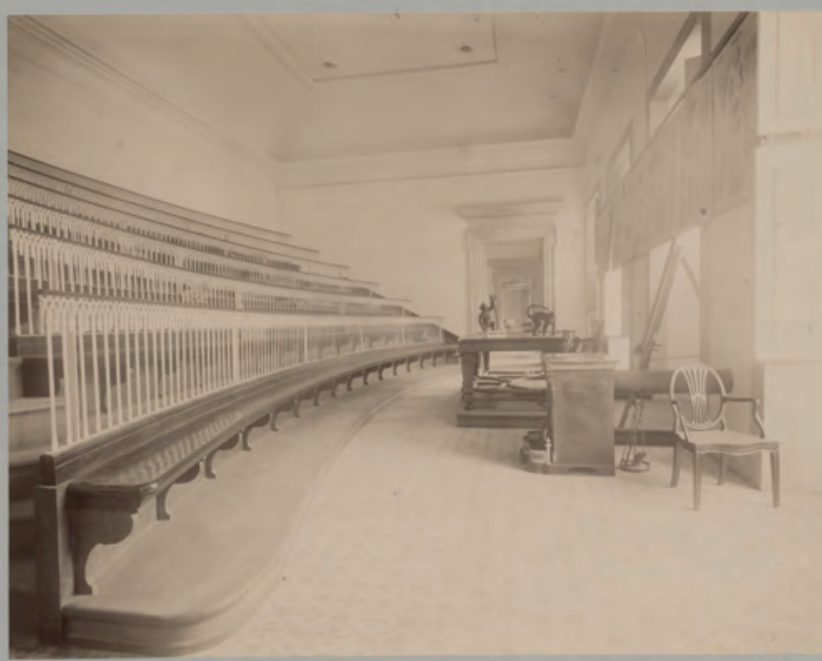

seink.

Figura 12 - Anfiteatro do Museu de História Natural. Fotografia de Augusto Bobone (ca. 1893). 


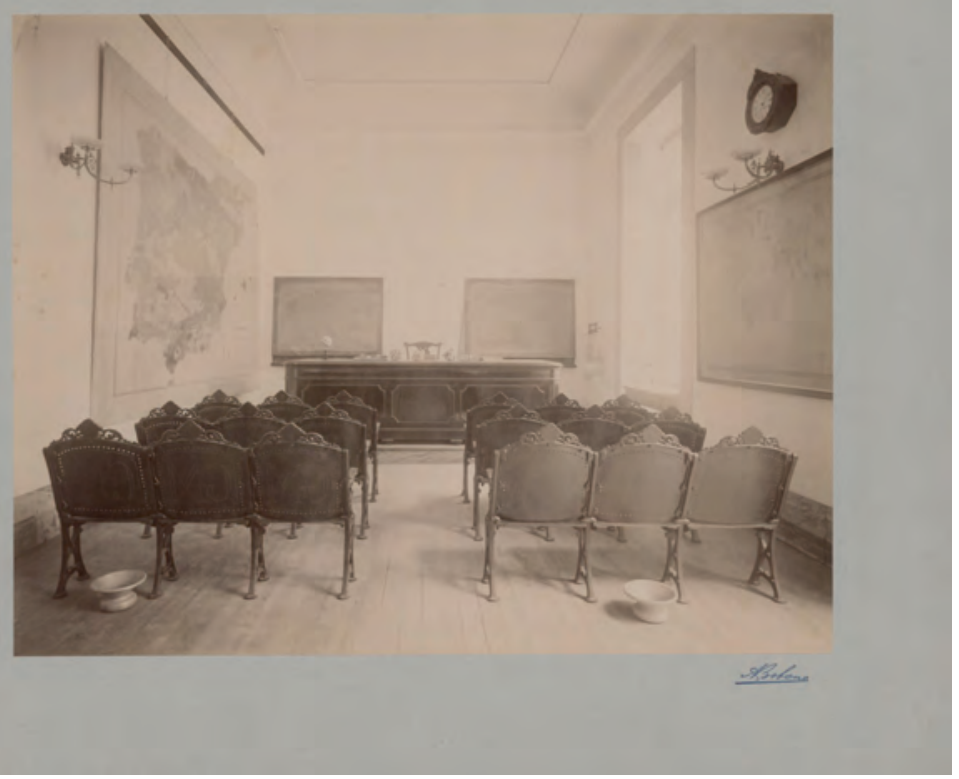

Figura 13 - Sala de Aula de Geologia. Fotografia de Augusto Bobone (ca. 1893).

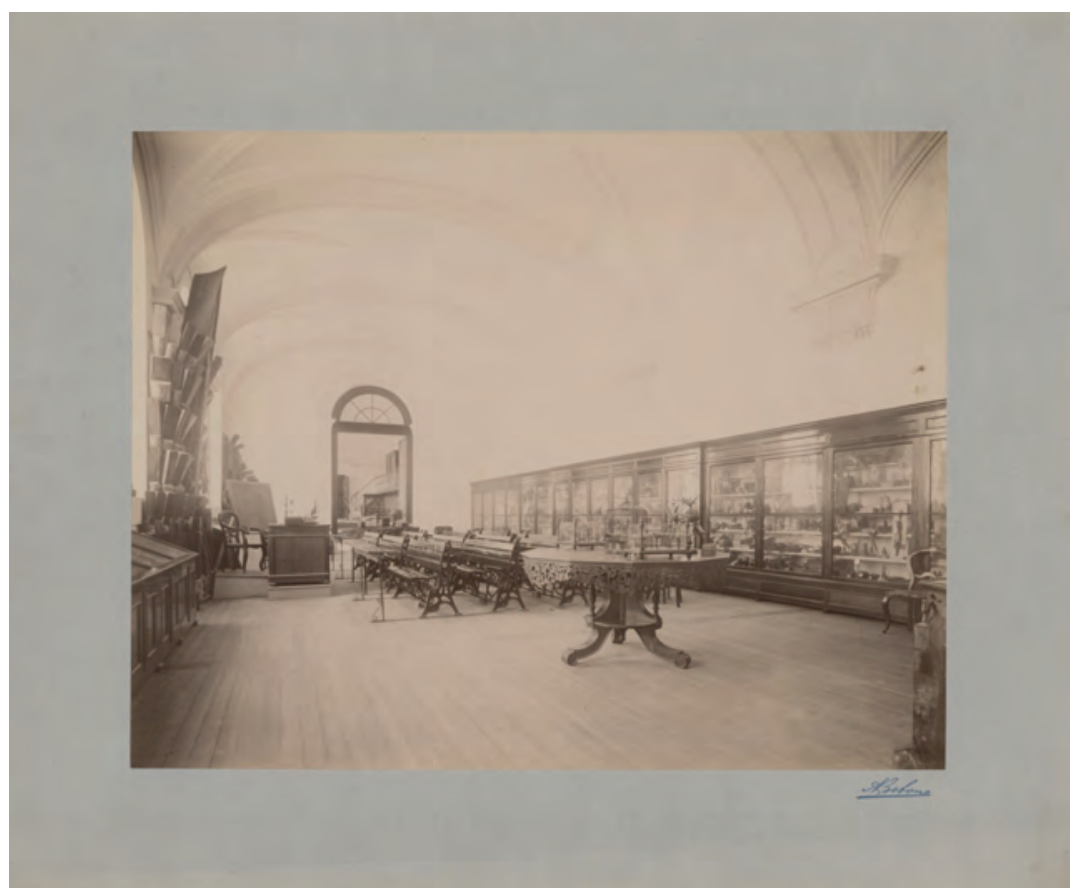

Figura 14 - Museu Botânico. Fotografia de Augusto Bobone (ca. 1893). 


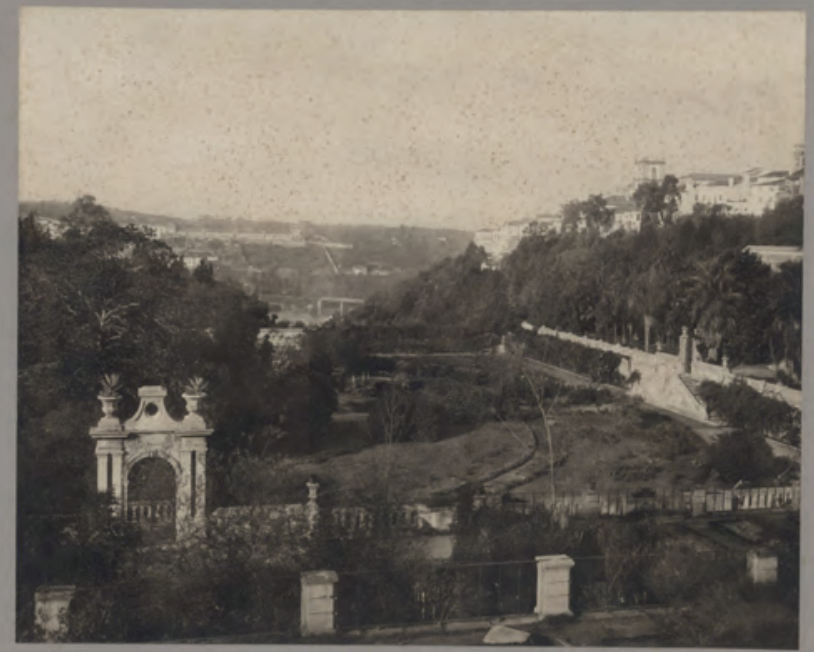

exsinemes

4.:Lisent:

Figura 15 - Jardim Botânico. Fotografia de Augusto Bobone (ca. 1902).

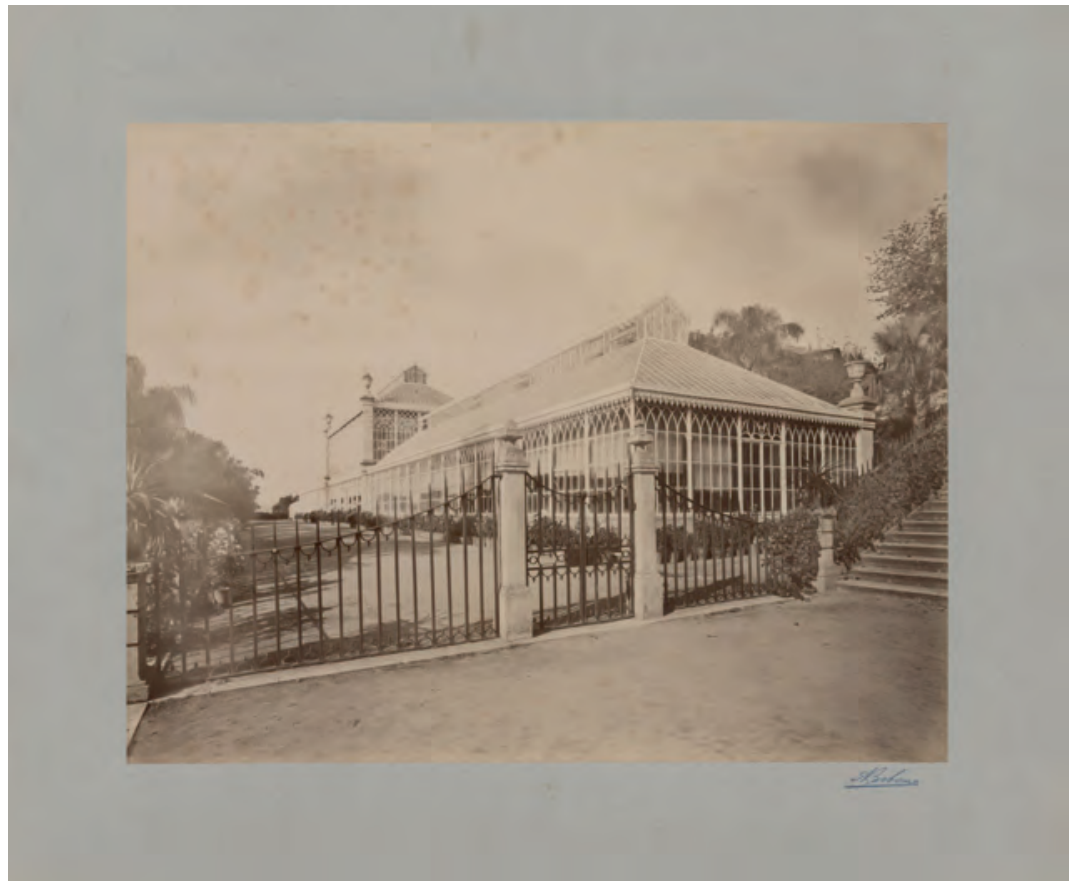

Figura 16 - Estufa do Jardim Botânico. Fotografia de Augusto Bobone (1902). 


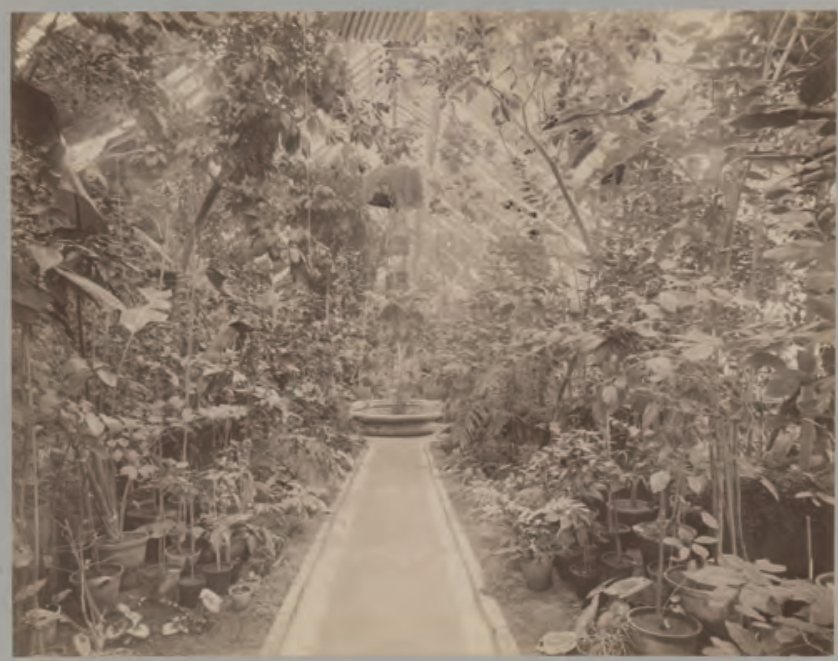

retios.

Figura 17 - Interior da estufa do Jardim Botânico. Fotografia de Augusto Bobone (1902).

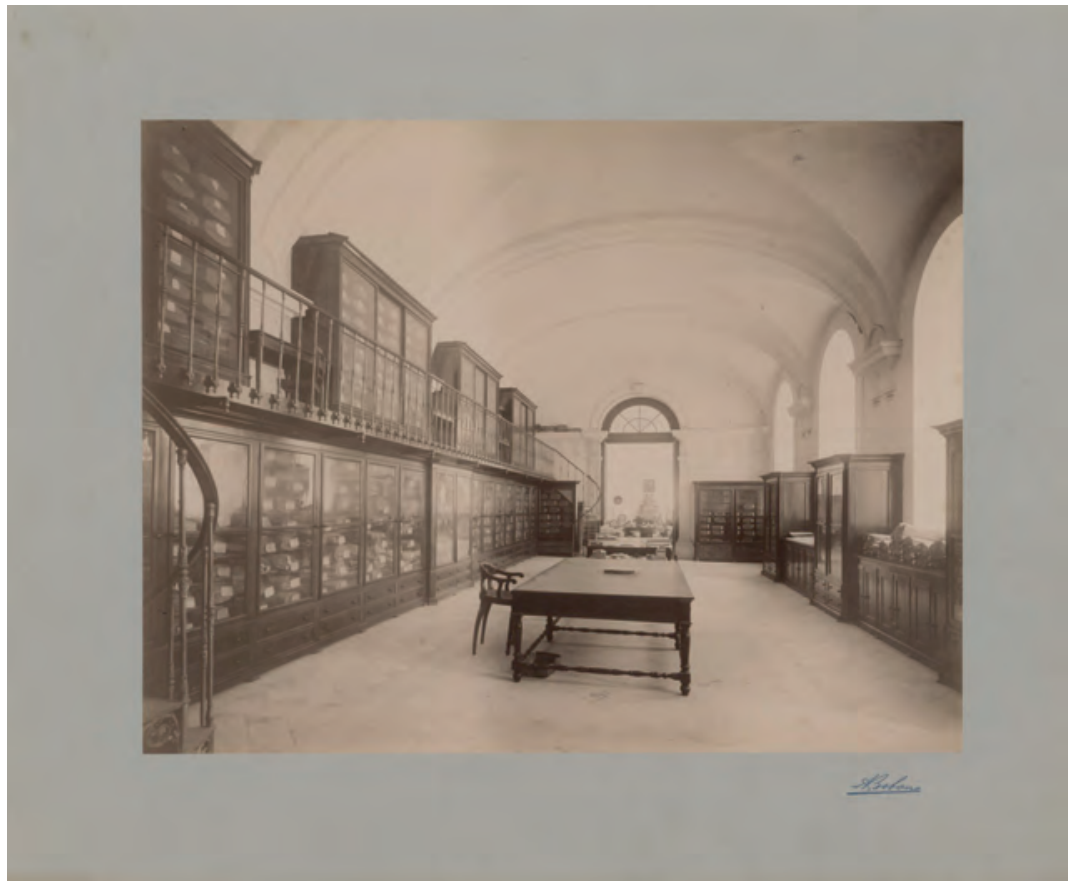

Figura 18 - O Herbário criado por Júlio Henriques. Fotografia de Augusto Bobone. (1902). 


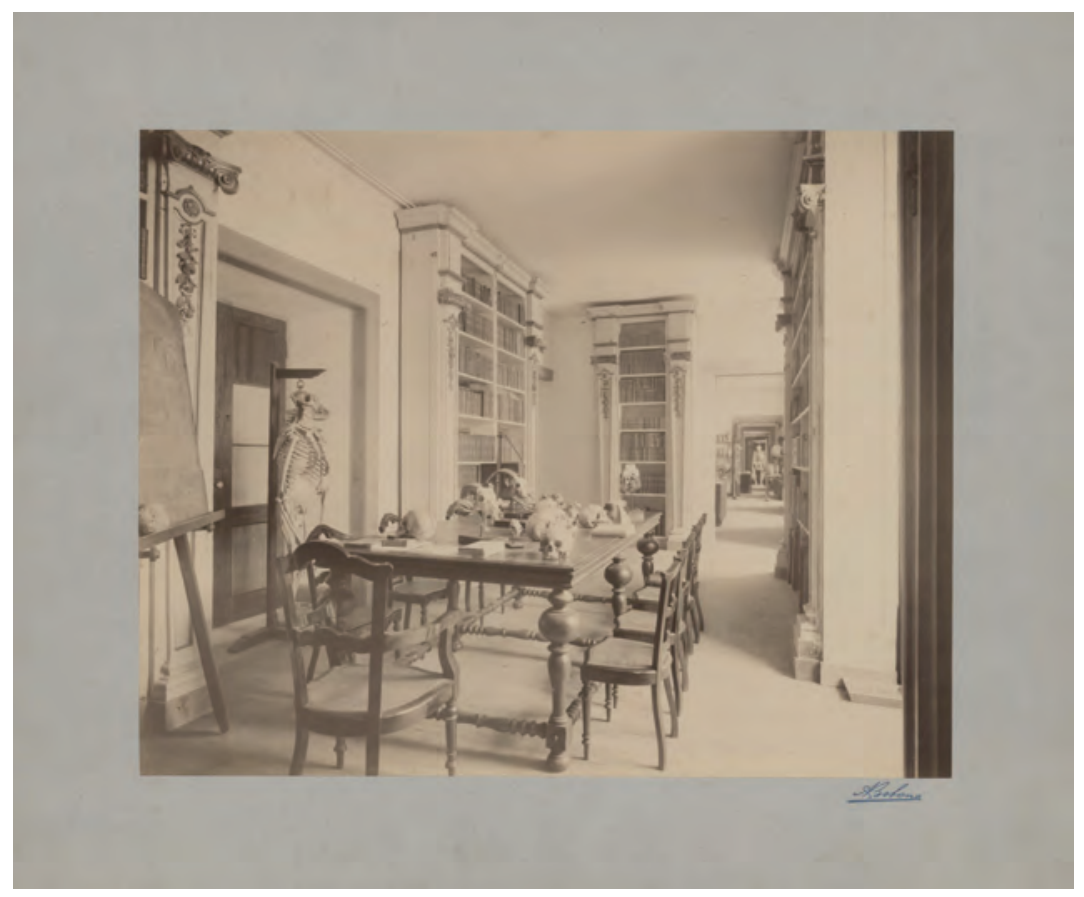

Figura 19 - Museu de Antropologia. Fotografia de Augusto Bobone. (ca. 1893).

\section{O Observatório Meteorológico e Magnético}

O final da década de 1850 ficou assinalado no Gabinete de Física Experimental da Faculdade de Philosophia pela criação de um centro de investigação dedicado aos estudos do Geomagnetismo. Esta iniciativa permitiu que alguns professores da Faculdade de Philosophia visitassem diversos observatórios geomagnéticos da Europa. Associados à criação do Observatório Meteorológico e Magnético (Fig. 20), foram estabelecidos contactos no estrangeiro por volta do ano de 1860, permitindo que no Gabinete de Física fosse intensificado o desenvolvimento do ensino das novas técnicas experimentais até ao final do século, reflectindo-se este facto na qualidade do ensino teórico e prático. Os professores eram os primeiros a expressar a opinião de que, até ao ano de 1861, o ensino da Física na Universidade de Coimbra era algo limitado, se atendermos ao estado de desenvolvimento em que se encontrava esta ciência. Este desenvolvimento era incomportável com um estudo profícuo numa única cadeira e no intervalo de um ano lectivo. Desta forma, os professores consideravam que o ensino da Física se tinha tornado demasiado elementar, resultando impraticáveis os meios técnicos de acção formativa dos estudantes, para que a observação e a experimentação constituíssem metodologias eficazes de transmissão de conhecimento. Para este défice qualitativo contribuía, principalmente, a falta de financiamento, que condicionava o desenvolvimento da Física Experimental em Coimbra. 


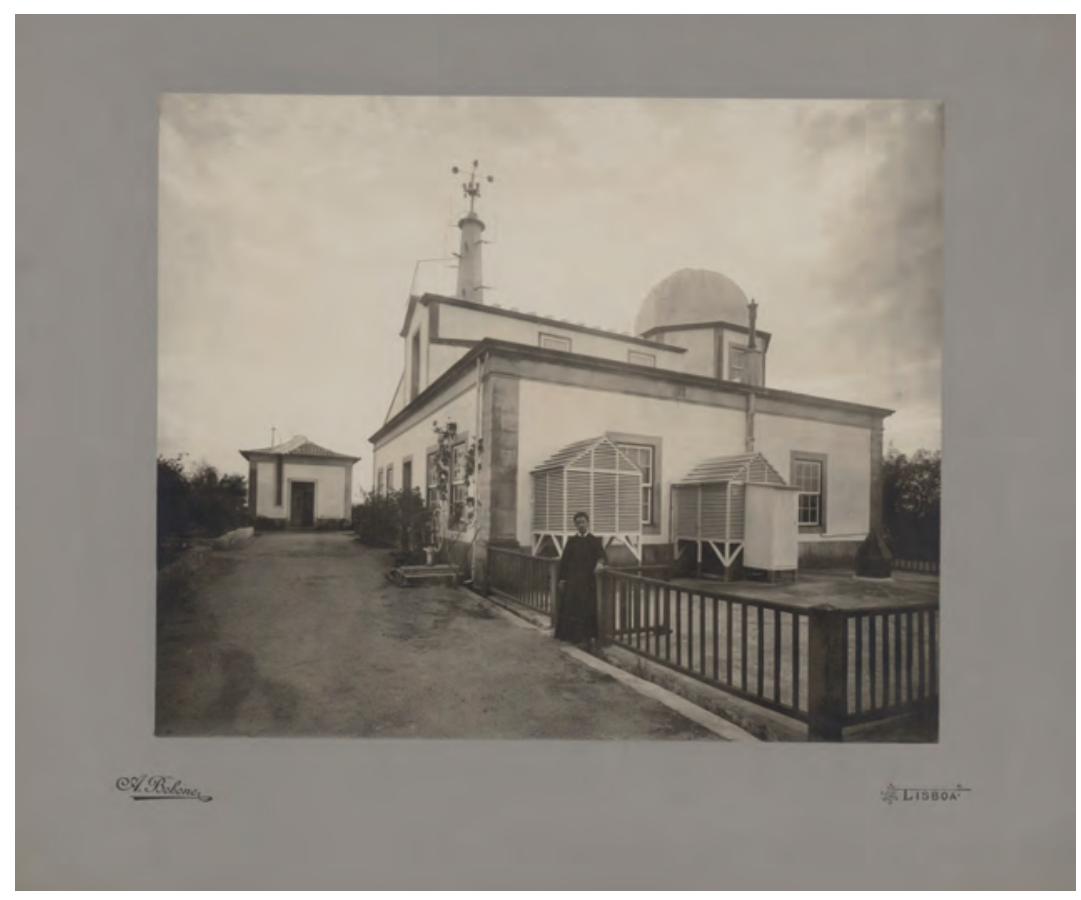

Figura 20 - Observatório Meteorológico e Magnético. Fotografia de Augusto Bobone. [1902].

Desde a fundação do Observatório Meteorológico e Magnético, ocorrida em 1863, que as ciências geofísicas assumiram relevo na Faculdade de Filosofia da UC. As observações meteorológicas e magnéticas, publicadas anualmente, eram partilhadas com várias dezenas de instituições nacionais e internacionais. António Santos Viegas tomou posse do lugar de director daquele observatório em 1880, mantendo-se nesse lugar até à sua morte em 1914. Um foco de intervenção de Santos Viegas foi a aquisição de novos instrumentos, não apenas para a meteorologia mas também para as determinações geomagnéticas e sismológicas. Em relação a esta última área, Santos Viegas foi mesmo pioneiro a nível nacional. Por ocasião do seu falecimento, no volume LIII das Observaçôes meteorológicas, magnéticas e sísmicas (Fig. 21) foi publicado um obituário no qual se enaltecia o seu mérito científico e contributo para o desenvolvimento da Física e da Geofísica em Coimbra.

Os primeiros registos sismológicos efectuados no nosso país tiveram lugar em Coimbra, tendo sido adquirido um primeiro sismógrafo ainda em 1891. Foi em 1903 que foi montado um pêndulo horizontal de Milne, tendo sido logo iniciadas as primeiras observações, cujo principal responsável foi Egas Fernandes Cardoso e Castro, um jovem bacharel da Universidade de Coimbra. Egas e Castro publicou em 1909 um dos primeiros estudos sismológicos realizados em Portugal, no qual calculou a profundidade do hipocentro do sismo de 23 de Abril de 1909, com epicentro em Benavente. A sua actividade em Coimbra foi contudo efémera, visto que se transferiu, nesse mesmo ano, para o Serviço Meteorológico dos Açores por falta de vaga no Observatório coimbrão. 


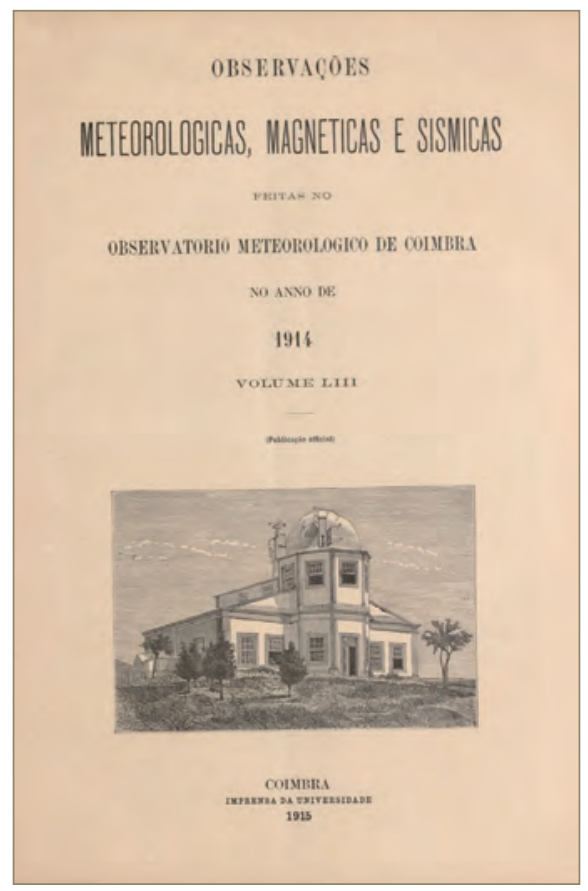

Figura 21 - Observações meteorológicas, magnéticas e sísmicas. Publicação periódica do Observatório Meteorológico, Magnético e Sismológico que posteriormente passou a designar-se Instituto Geofísico da Universidade de Coimbra.

\section{A Física na Segunda Metade do Século XiX}

Jacinto António de Sousa, António dos Santos Viegas, António Meirelles Garrido e Henrique Teixeira Bastos foram os principais impulsionadores do desenvolvimento do ensino da Física Experimental em Coimbra na segunda metade do século XIX. Os Cursos de Física Experimental orientados por António dos Santos Viegas foram muito influenciados pelas observaçōes que fez durante as viagens científicas a várias capitais europeias a partir dos anos de 1866 e 1867. As visitas aos principais centros universitários e escolas técnicas tinham por objectivo conhecer os melhores observatórios meteorológicos e magnéticos europeus, bem como proceder a um estudo sobre o estado de desenvolvimento da Física Experimental e das suas modernas metodologias de ensino. Por portaria de 24 de Outubro de 1866, foi encarregado de uma viagem científica pelos principais países da Europa, devendo visitar as universidades e escolas mais conceituadas, estudar a organização do ensino das ciências filosóficas, a organização e dinâmica dos diversos estabelecimentos científicos e das fábricas. O Conselho da Faculdade recebeu com muito entusiasmo esta resolução do governo, e encarregou uma comissão de redigir as instruçôes convenientes para esta viagem, as quais foram aprovadas em 10 de Outubro de 1867. Tendo sido encarregado de estudar nos melhores centros universitários europeus os processos práticos da Física Experimental, de visitar os estabelecimentos de ciências físicas e naturais bem como observar os méto- 
dos e a organização do ensino nas universidades mais prestigiadas da Europa, Santos Viegas começou por visitar Madrid. O ensino da Física praticado nas escolas que visitou na capital espanhola não lhe deixou boas impressões. Em Paris interessou-se pelos cursos de Física orientados por Desains na Sorbone; Bertin no Colégio de França; Jamin na Escola Politécnica e de Bequerel no Conservatório de Artes e Ofícios. Também visitou universidades na Alemanha, Áustria, Bélgica, Inglaterra, Escócia, etc..

Segundo Santos Viegas, a preparação que os alunos franceses tinham na sua formação do ensino secundário era de melhor qualidade do que a observada em Portugal. A exemplo do que acontecia em Coimbra, também em Paris os docentes das cadeiras de Física começavam a sentir algumas dificuldades em transmitir aos seus alunos um programa de ensino adequado ao estado de desenvolvimento da ciência em apenas um ano lectivo. Tal como acontecia nas escolas do ensino superior em França, Santos Viegas também incluía várias experiências didácticas no seu curso em Coimbra, recorrendo para o efeito a diverso equipamento científico e didáctico moderno. No entanto, como ele próprio afirmou nos relatórios das suas viagens, também desconhecia muitos processos que os livros não descreviam, os quais só se aprendiam, vendo-os praticar e praticando-os ao lado de quem os conhecia.

Santos Viegas conheceu os preparadores da Sorbone - Bourbouse, Ruhmkorff, Koening e Bianchi - dos quais existem em Coimbra alguns instrumentos por eles concebidos. Bianchi era também preparador das experiências para os cursos de Física do professor Bequerel. Também conheceu Regnault que era professor proprietário do curso de Física do Colégio de França e neste estabelecimento executou importantíssimos trabalhos em diversos ramos da Física. Este professor foi considerado por Joule como um dos melhores projectistas europeus de instrumentos científicos da sua geração. São inúmeros os aparelhos, principalmente de termodinâmica, por ele desenhados e que se encontram referenciados na mais diversa bibliografia. O Gabinete de Física Experimental de Coimbra foi equipado com vários exemplares de instrumentos concebidos por aquele professor e investigador. No ano da visita de Santos Viegas a Paris, também estabeleceu contactos com Bertin e teve conhecimento da forma como este professor organizava o ensino da electricidade, dando muita importância aos trabalhos mais recentes feitos na Alemanha. Foi numa destas liçôes que Santos Viegas viu funcionar pela primeira vez duas novas máquinas eléctricas de Holtz e A. Bertsch, sendo as experiências relativas a esta última efectuadas pelo próprio inventor. Tratava-se de dois aparelhos singulares, que se carregavam electrizando uma pequena lâmina de caoutchouc, e permitiam obter correntes contínuas de intensidade comparáveis às de uma bobine de Ruhmkorff. Os contactos estabelecidos por Santos Viegas permitiram que se procedesse à aquisição de uma máquina de Holtz para o Gabinete de Física de Coimbra. No Conservatório de Artes e Ofícios, conheceu Bequerel que apresentava um curso aplicado às artes. Este curso, tal como todos os cursos daquele estabelecimento, estava adequado para a instrução dos operários e artistas, que ali acorriam em grande número. Santos Viegas interessou-se particularmente pela forma como estava organizado o ensino científico na Escola Politécnica de Paris. Este curso bienal era feito em alternância por dois professores: Jamin e Verdet, tendo o segundo falecido no ano de 1866, sendo substituído pelo professor Alfred Cornu. Os programas de ensino da Física Experimental na Universidade de Coimbra dos professores Jachinto Antonio de Sousa e Antonio dos Santos Viegas eram muito semelhantes ao 
da Escola Politécnica de Paris. Na escola francesa, o professor Jamin seguia nas suas liçôes quase a mesma ordem dos assuntos tratados no seu livro, dos quais existem exemplares na biblioteca do Departamento de Física da Universidade de Coimbra.

Para além destes cursos, Santos Viegas também teve oportunidade de assistir a várias conferências científicas que decorreram no Ateneu, no Observatório e na Sorbone, durante o Inverno de 1866-1867. A frequência dos cursos, na qualidade de simples espectador, proporcionou ao professor do Gabinete de Física da Universidade de Coimbra a ocasião de ver funcionar muitos aparelhos de concepção recente, embora a maior parte não era a primeira vez que os contactava, já que o Gabinete de Coimbra se encontrava equipado com instrumentos modernos. Para ver de perto como as experiências se preparavam e, com o objectivo de poder trabalhar sob a orientação de um homem que conhecesse bem os instrumentos, dirigiu-se a Duboscq, reputado construtor de instrumentos científicos, a quem encomendou alguns aparelhos que vieram aumentar a colecção de instrumentos destinados ao ensino da Física Experimental em Coimbra. Sendo aconselhado por Duboscq a contactar o preparador da Sorbone, Santos Viegas conseguiu obter de Bourbouze autorização para acompanhar os trabalhos em curso no laboratório de Física Experimental dessa prestigiada escola. Este preparador gozava de excelente reputação junto da comunidade científica de Paris, tendo trabalhado para mestres tão distintos como Pouilett, Despretz, Desains e Jamin. Ao lado de Bourbouze, Santos Viegas assistiu à preparação das experiências para o curso da Faculdade de Ciências e aos ensaios para as Soirées Scientíficas. No laboratório realizou trabalhos de determinação de densidades dos corpos sólidos e líquidos, construção de termómetros, aplicação da máquina de dividir a graduação de tubos de vidro e ao traçado de escalas micrométricas, métodos gráficos para determinar a duração das vibraçôes sonoras, processos de galvanoplastia, douradura e prateadura química, fotografia, com aplicação especial às projecçôes usadas nos cursos de Física, clivagem dos cristais birrefrangentes e trabalhos de soprar o vidro.

A aquisição de instrumentos científicos modernos para o Gabinete de Física Experimental não se limitou apenas aos fabricantes de Paris. Este facto explica a grande variedade de fabricantes de instrumentos de diversos países europeus representados na numerosa colecção que actualmente faz parte do valioso espólio do Museu de Física da Universidade de Coimbra (Fig. 22). Esta colecção pode ser considerada bem representativa do avanço tecnológico que teve a Física Experimental até ao início do século XX. Trata-se de uma colecção muito completa em todos os domínios desta ciência e que também acompanhou os aspectos mais importantes dos primeiros desenvolvimentos experimentais da Física Atómica moderna.

Santos Viegas foi um professor muito influente na Academia de Coimbra durante toda a segunda metade do século XIX. Doutorou-se em Filosofia em 30 de Outubro de 1859, sendo-lhe concedido gratuitamente o grau de doutor, que era nesses tempos a maior prova de consideração dada aos alunos de superior talento e óptima aplicação nos estudos. Pouco tempo depois, a 22 de Fevereiro de 1860, foi despachado Lente Substituto da mesma Faculdade, com 24 anos ainda incompletos, lugar de que tomou posse em 17 de Março seguinte, e que ainda conservava à data do seu falecimento, tendo sido Lente Catedrático de Prima, decano e director da sua Faculdade. Foi deputado, eleito pela Covilhã, nas legislaturas de 1868 e 1871, e par do reino efectivo pela Universidade. Por decreto de 13 de Janeiro de 1890 foi nomeado reitor da Universi- 


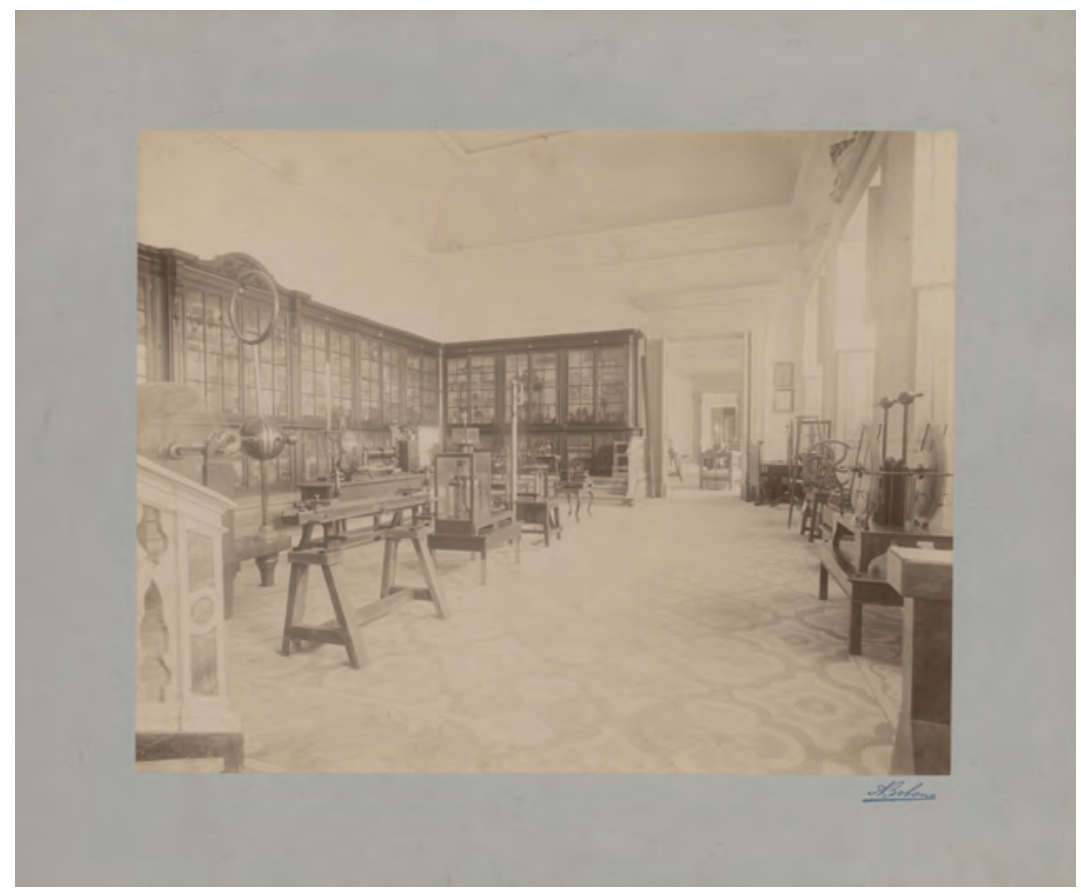

Figura 22 - Uma das salas do Gabinete de Física. Fotografia de Augusto Bobone. - [ca 1893].

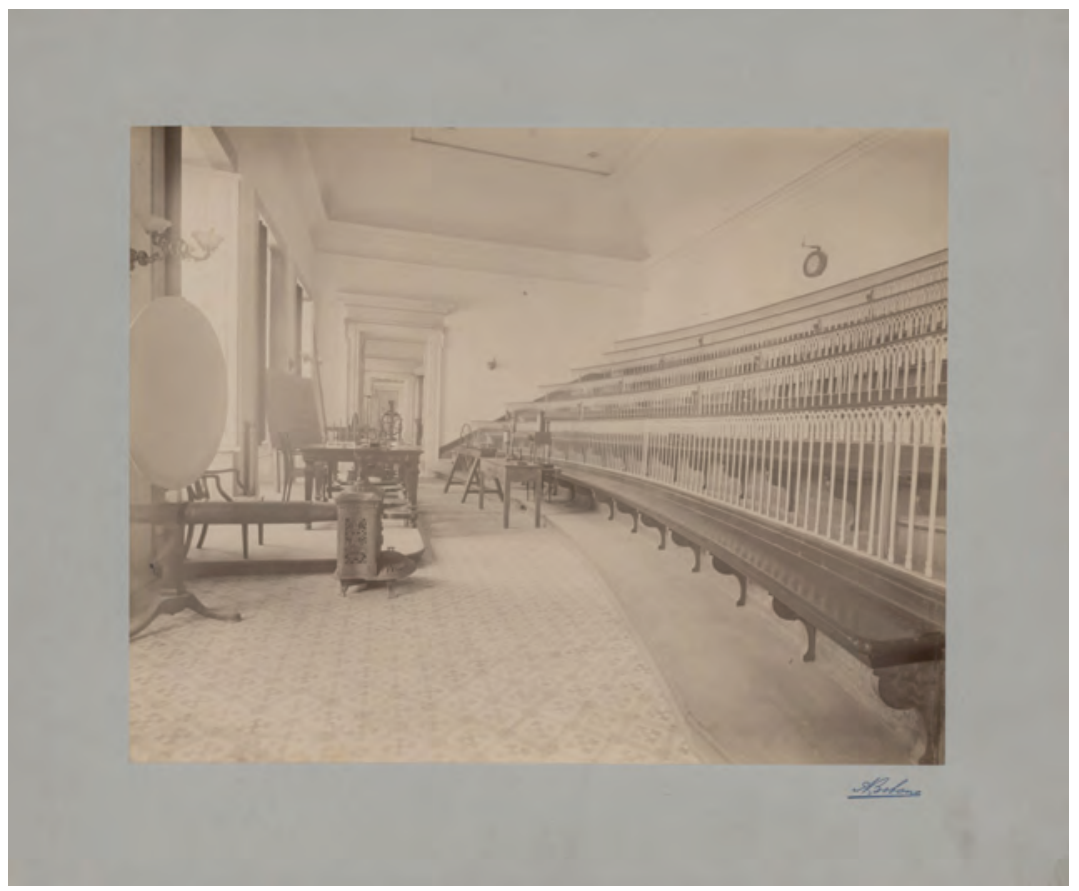

Figura 23 - O Anfiteatro do Gabinete de Física. Fotografia de Augusto Bobone. [ca 1893]. 
dade, de que tomou posse em claustro pleno a 31 do mesmo mês. Na sua reitoria foi homenageado pelas visitas do Rei D. Carlos, Rainha D. Amélia, e do Príncipe Real D. Luiz Filipe, no mês de Julho de 1892. A 6 de Agosto seguinte foi exonerado do cargo. Em 1896 foi novamente nomeado reitor, cargo de que se exonerou em 1898. Em Abril de 1906 tornou a ser nomeado reitor. Representou Portugal em muitos congressos científicos, em Roma, Paris e Viena, etc. No ano de 1881 foi mandado a Paris para representar Portugal no Congresso e Exposição de Electricidade. Por essa ocasião recebeu do governo francês o grau de Cavaleiro da Ordem da Legião de Honra. Em 17 de Março de 1910, realizou-se na Universidade uma grande solenidade. No anfiteatro do Gabinete de Física (Fig. 23) o conselheiro António dos Santos Viegas, que nesse dia completava 50 anos de carreira docente, foi alvo de uma importante e majestosa manifestação de apreço e consideração pela sua incansável dedicação ao magistério universitário. Durante os cinquenta anos de serviços prestados na Universidade de Coimbra, o Gabinete de Physica Experimental teve um desenvolvimento assinalável.

A reforma curricular de 1861, que também assinalou o início da concretização do projecto de criação do Observatório Meteorológico e Magnético, coincidiu com um período de alguma prosperidade científica no Gabinete de Física. No ano de 1877 Antonio Meirelles Garrido submeteu para o acto de conclusões magnas na Faculdade de Filosofia a dissertação inaugural subordinada ao título Theoria mathematica da propagação da luz nos meios homogeneos. O Congresso de Electricidade, reunido em Paris em Setembro de 1881, no qual Portugal foi representado por António dos Santos Viegas, teve como objectivo fundamental o estabelecimento da uniformidade das unidades eléctricas. Antes deste Congresso reinava a maior confusão na nomenclatura e definição das unidades eléctricas. Em geral, na avaliação da mesma grandeza física, cada experimentador propunha a sua unidade, segundo as necessidades de ocasião. Deste modo, o Congresso estabeleceu um sistema racional de unidades eléctricas, adoptando com leves modificações o sistema de unidades racional usado em Inglaterra e pondo termo às divergências até então existentes. Em Coimbra, este foi um assunto que mereceu especial atenção na Faculdade de Philosophia. Em Maio de 1884 foi apresentada a dissertação inaugural sob o título Unidades Eléctricas, defendida por Henrique Teixeira Bastos, para o acto de Conclusões Magnas integralmente dedicada à definição de um sistema racional de unidades eléctricas, definição de padrões de resistências eléctricas e força electromotriz. No ano seguinte, em Fevereiro de 1885, Henrique Teixeira Bastos, concluiu a sua dissertação de concurso apresentada à Faculdade de Philosophia sobre a Theoria electromagnetica da Luz (Fig. 23).

No dia 3 de Julho de 1886, foram analisadas e aprovadas as Theses e Dissertação Inaugural submetidas por Aarão Ferreira de Lacerda. A dissertação inaugural era subordinada ao título Equaçôes Geraes da Thermodynamica e foi defendida no dia 30 de Outubro de 1886 perante um júri presidido por António dos Santos Viegas. $\mathrm{Na}$ área específica da Meteorologia, em Maio de 1892, o licenciado em Philosophia, Bernardo Ayres, concluiu a sua dissertação intitulada A circulação Atmospherica e a Previsão do Tempo. Em 1896 Teixeira Bastos publicou um artigo na revista científica $O$ Instituto, onde anunciava as mais recentes descobertas relativas aos raios $\mathrm{X}$ que foram tornadas públicas em Dezembro de 1895. Em Fevereiro de 1896, pouco mais de um mês depois da publicação do artigo onde Röntgen tornava pública a sua descoberta, fizeram-se as primeiras experiências em Coimbra. No dia 1 de Março de 1896, 
o jornal $O$ Século publicou na primeira página um extenso artigo intitulado $A$ Photographia atravez dos corpos opacos, onde se dava uma notícia das primeiras experiências feitas em Portugal. Ainda em Fevereiro desse ano foram feitos os primeiros ensaios de aplicação dos raios $\mathrm{X}$ no diagnóstico clínico. Os instrumentos utilizados nas primeiras experiências realizadas em Coimbra estão actualmente no Museu da Ciência da Universidade de Coimbra (Fig. 24).

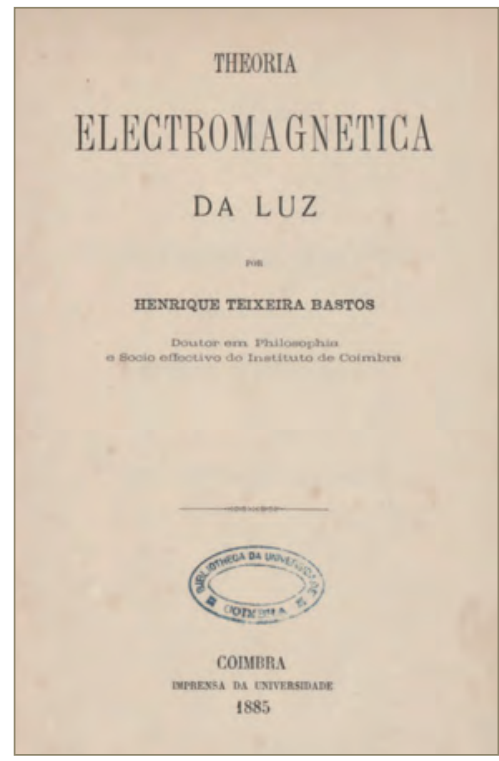

Figura 23 - Theoria electromagnetica da luz por Henrique Teixeira Bastos.

- Coimbra: Imprensa da Universidade, 1885.

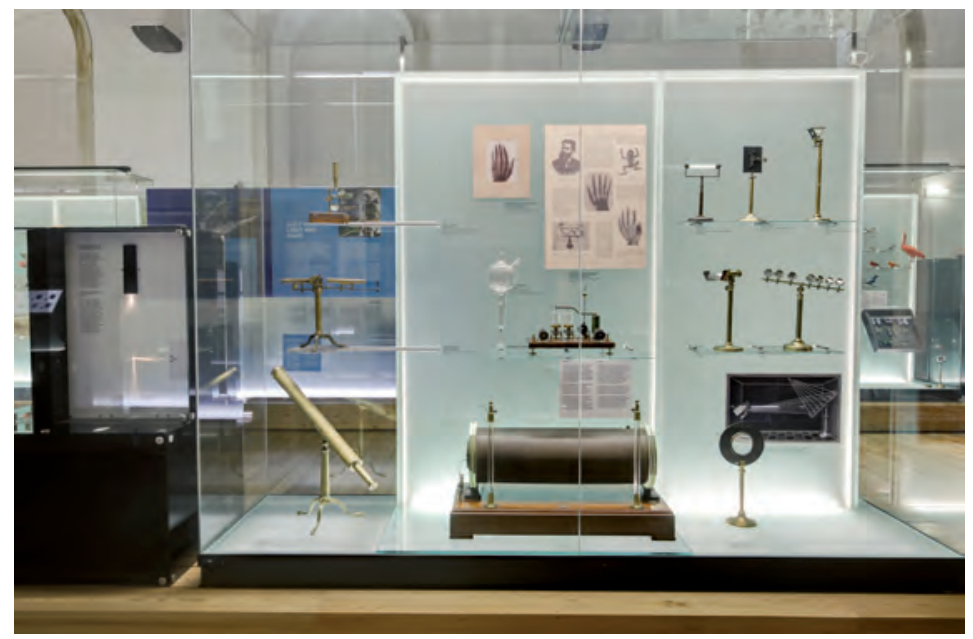

Figura 24 - A parte central da fotografia ilustra os instrumentos utilizados nas experiências de raios X na Universidade de Coimbra, em 1896, com a reprodução das primeiras imagens obtidas.

(Museu da Ciência da Universidade de Coimbra - http://www.museudaciencia.pt/) 
Nos anos de 1896 e 1897 intensificaramse os estudos sobre os raios X no Gabinete de Física de Coimbra. Em Maio de 1897 o licenciado em Philosophia Natural, Álvaro José da Silva Basto, submeteu a dissertação inaugural para o acto de conclusões magnas na Faculdade de Philosophia da Universidade de Coimbra intitulada Os raios cathódicos $e$ os raios $X$ de Röntgen (Fig. 25). Silva Basto começava por referir-se aos estudos experimentais de descargas eléctricas em gases, descrevendo pormenorizadamente a aparência das descargas em diversas condiçôes, e os métodos de preparação das descargas, seguindo-se o estudo experimental dos raios catódicos e a descrição do estado eléctrico dos tubos de descarga. Sobre as propriedades dos raios catódicos, referia-se às suas acções luminescentes, acções químicas e fotográficas, mecânicas, caloríficas e acções eléctricas. Estudou a acção de um campo magnético e de um campo electrostático sobre os raios catódicos. Estudos sobre a propagação no interior do tubo, determinação da velocidade, reflexão e transparência, propagação no exterior do tubo (experiências de Lenard) também eram contemplados na sua dissertação. A respeito da natureza dos raios catódicos, analisou a teoria da condução molecular, teoria da condução electrolítica, teoria da natureza material dos raios catódicos, etc. A parte referente aos raios de Röntgen iniciava-se com um estudo sobre as suas propriedades ópticas, seguindo-se experiências sobre acções luminescentes e fotográficas, acções eléctricas e o estudo comparativo com outras radiações novas como os raios de Becquerel. Depois de um capítulo dedicado aos modelos teóricos explicativos da natureza dos raios X, desenvolveu o estudo das técnicas de produção e de aplicação. Nesta dissertação mostrou um conhecimento profundo da evolução teórica e técnica do assunto. Entre a extensa bibliografia publicada na Europa e nos Estados Unidos, e referenciada na tese defendida em Coimbra, merecem destaque especial pela sua actualidade as comunicações apresentadas na Academia das Ciências de Paris por Perrigot, no dia 20 de Abril de 1897, publicada no Compte Rendus (p. 857), por Gustav Le Bon em 26 de Abril (p. 892) e de Henri Becquerel datada de 10 de Maio do mesmo ano (p. 984). A última conferência foi apresentada cerca de vinte dias antes de Silva Basto concluir o seu estudo!

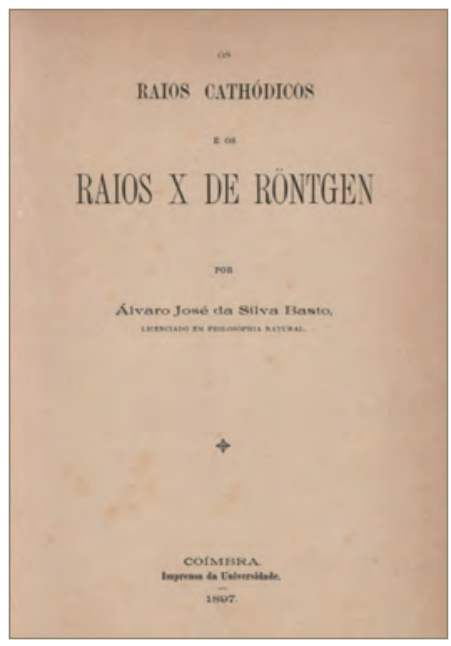

Figura 25 - Os raios cathódicos e os raios x de Rontgen por Álvaro José da Silva Basto.

- Coimbra: Imprensa da Universidade, 1897. 


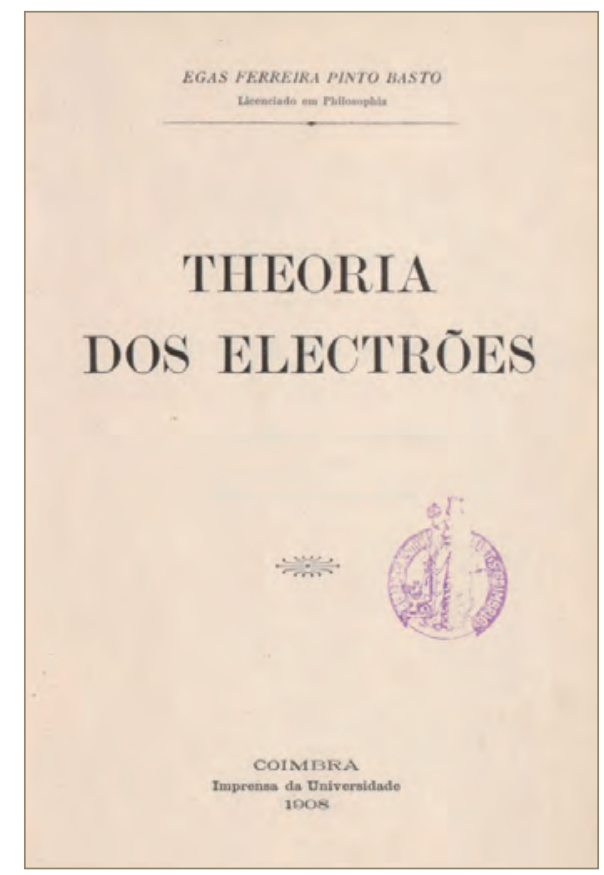

Figura 26 - Theoria dos electrōes por Egas Ferreira Pinto Basto. - Coimbra: Imp. da Universidade, 1908.

Ainda no ano de 1897 foram submetidas duas dissertações subordinadas ao tema Oscilaçôes Eléctricas, ambas de autoria de Vellado Alvez Pereira da Fonseca. O primeiro volume era intitulado Optica das Oscilaçôes, e o segundo Efeito das Oscilaçôes. O final do século XIX e o início do século XX ficou assinalado no Gabinete de Física de Coimbra pela introdução dos estudos experimentais mais recentes sobre a constituição atómica da matéria. Com efeito, em 1908 foi apresentada a dissertação inaugural para o acto de Conclusões Magnas na secção de Sciencias PhysicoChymicas da Faculdade de Philosophia, da autoria de Egas Ferreira Pinto Basto. No mesmo ano o jovem licenciado submeteu uma nova dissertação para o concurso ao magistério na primeira secção da Faculdade de Philosophia Natural, a qual era uma continuação do seu estudo sobre a Theoria dos Electrôes (Fig. 26). Este trabalho é bem elucidativo do grau de actualidade com que alguns assuntos da Física Moderna eram tratados em Coimbra. Na primeira parte da sua dissertação, Pinto Basto referia-se ao estudo experimental dos raios catódicos, incluindo sua produção e propriedades, natureza dos raios catódicos, determinação da velocidade dos raios catódicos e do valor e/m. No capítulo dedicado ao estudo experimental da ionização dos gases fazia referência às descargas eléctricas produzidas pela acção da luz ultravioleta ou efeito fotoeléctrico, ao estudo experimental dos raios canais e determinação da carga e massa dos iōes. Um capítulo era dedicado às radiações emitidas pelas substâncias radioactivas, referindo-se às propriedades dos raios $\alpha, \beta$ e $\gamma$. A segunda parte do seu trabalho iniciava-se com o estudo do fenómeno de Zeeman, constituição do átomo, teorias sobre a condutibilidade metálica, referindo-se aos efeitos de Peltier e de Hall, arranjo 
dos electrôes no átomo de acordo com os resultados experimentais, referindo-se ao modelo do japonês Nagaoka (1903), de que tomou conhecimento através de dois artigos publicados na revista Nature, em Londres, em 25 de Fevereiro e 9 de Julho de 1904. A maior parte do trabalho tinha como referência os estudos mais recentes de Joseph John Thomson e Ernest Rutherford, analisando assuntos como a lei periódica, propriedades electroquímicas e valência, radioactividade, determinação do número de electrōes existentes num átomo e a sua distribuição em anéis segundo o modelo de Thomson, determinação das dimensões da esfera de electricidade positiva, origem da massa do átomo, etc.

Em 1914 Francisco Martins de Sousa Nazareth realizou um estágio de curta duração no laboratório de Marie Curie. De regresso a Portugal, executou um dos primeiros trabalhos experimentais no nosso país sobre radioactividade, tendo todo o equipamento sido montado no Laboratório de Física, com a excepção de um eléctrodo de quadrante Dolezalek. Este trabalho foi publicado na dissertação que o autor apresentou para 2. ${ }^{\mathrm{a}}$ assistente da Faculdade de Ciências da Universidade de Coimbra, em 1915, intitulada Ionização dos gases em vaso fechado (Fig. 27). No ano seguinte, publicou um artigo n'O Instituto onde descreveu o funcionamento do electrómetro de folha de ouro.
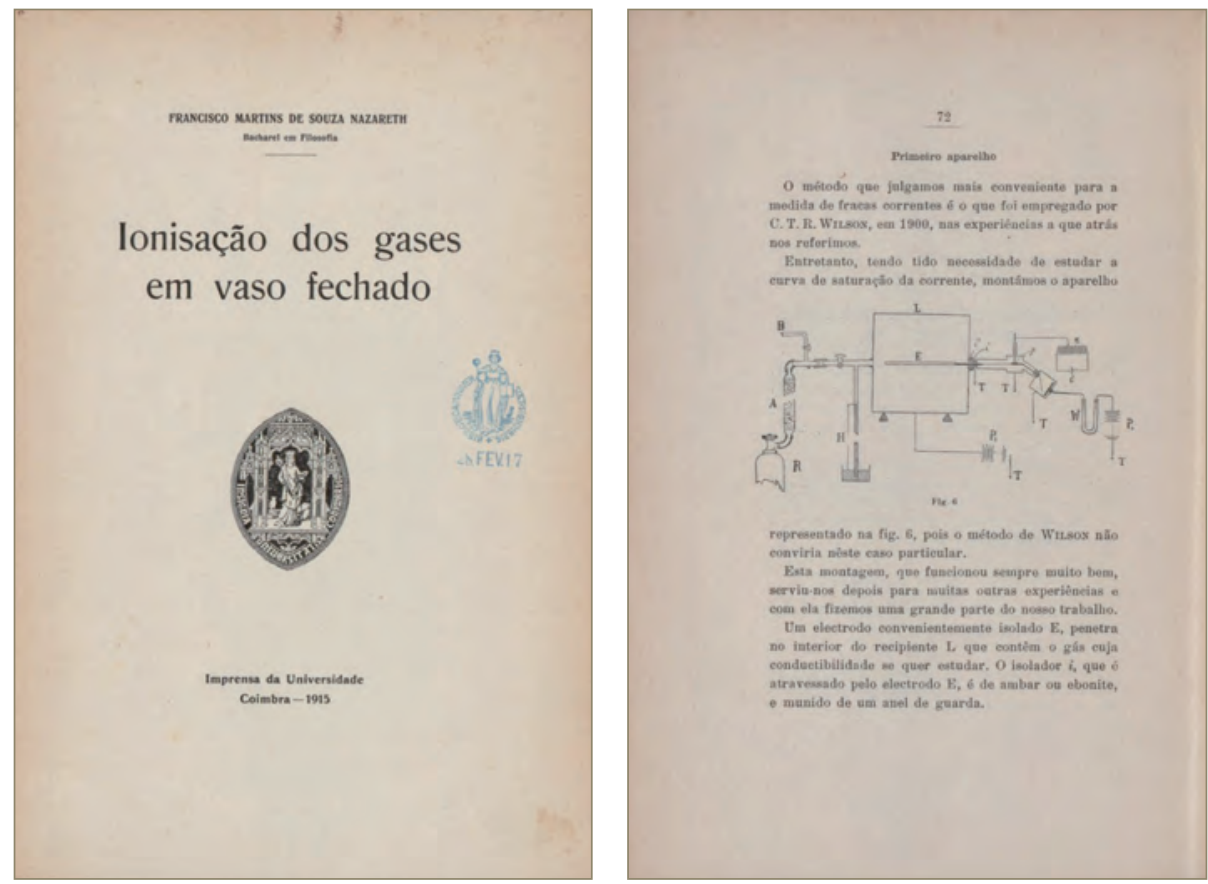

Figura 27 - Ionisação dos gases em vaso fechado de Francisco Martins de Souza Nazareth.

- Coimbra: Imprensa da Universidade de Coimbra, 1915. À direita está representada primeira experiência de radioactividade realizada em Coimbra. Todo o equipamento foi feito no Laboratório de Física, excepto o eléctrodo de quadrante de Dolezalek. 


\section{A Criação da Faculdade de Ciências}

Em 1911 deu-se a primeira grande reorganização do século XX no ensino das ciências físico-matemáticas e histórico-naturais na Universidade de Coimbra. Efectivamente, durante o 1. ${ }^{\circ}$ Governo da República, a Universidade de Coimbra foi reformatada. As Bases da Nova Constituição Universitária, de 19 de Abril de 1911, promulgavam então a reforma do Ensino Superior. Uma das medidas tomadas veio oficializar uma situação que na prática se verificou ao longo de todo o século XIX. A Congregação da Faculdade de Ciência reunida a 11 de novembro de 1913 aprovou o relatório relativo ao período de 1911 a 1913, do qual foi relator Henrique Teixiera Bastos (Fig. 28). Na realidade, desde a sua fundação, a História das duas Faculdades de Philosophia e de Mathematica, criadas pela Reforma Pombalina, dedicadas ao ensino dos vários ramos das ciências, foi caracterizada pela complementaridade pedagógica da formação dos seus estudantes e actividade científica dos seus docentes. Justificava-se a sua fusão apenas numa unidade de ensino. Estas duas Faculdades estão na origem da Faculdade de Ciências e os dois cursos até então existentes desdobraram-se em quatro: Matemática, Engenharia Geográfica, Ciências Físico-Químicas e Ciências Histórico-Naturais.

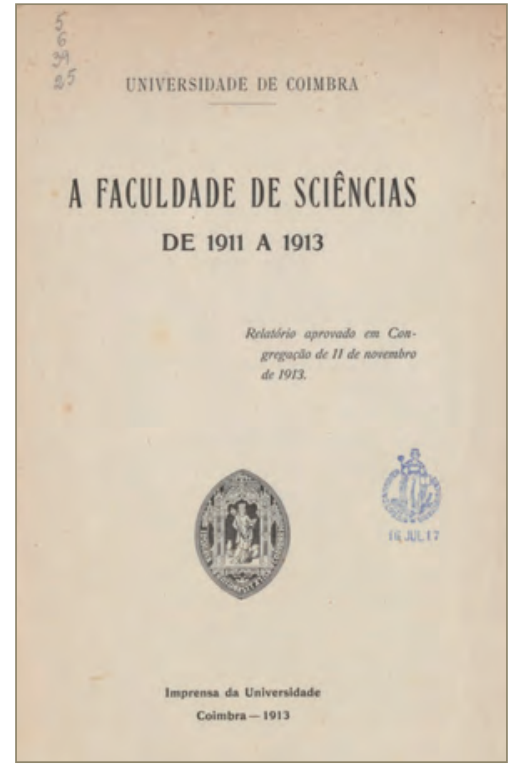

Figura 28 - A Faculdade de Sciências de 1911 a 1913: relatório aprovado em Congregação de 11 de novembro de 1913. Universidade de Coimbra; [H. Teixeira Bastos, relator].

- Coimbra: Imprensa da Universidade, 1913.

A Faculdade de Ciências ficou organizada em 3 secçôes: Ciências Matemáticas, Físico-Químicas e Histórico-Naturais, notando-se um aumento do número de cadeiras, sugerindo uma maior especialização dos estudantes e conferiam títulos de Bacharel, de Licenciado e de Doutor nas 3 secçóes. O organograma das disciplinas correspondentes aos cursos das 3 secções da nova Faculdade de Ciências estava assim organizado: 


\begin{tabular}{|c|c|}
\hline \multicolumn{2}{|c|}{ 1. ${ }^{a}$ Secção: Sciencias Mathematicas } \\
\hline \multicolumn{2}{|l|}{ 1. o Grupo: Analyse e Geometria } \\
\hline 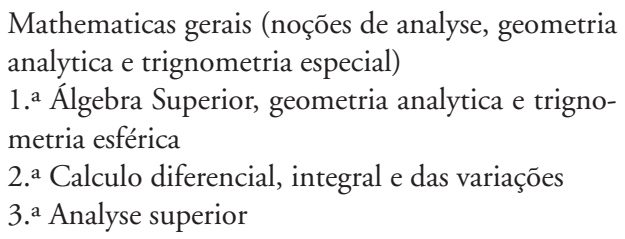 & $\begin{array}{l}\text { 4. }{ }^{a} \text { Calculo das probabilidades e suas appli- } \\
\text { caçôes } \\
\text { 5. }{ }^{\mathrm{a}} \text { Geometria projectiva } \\
\text { 6. }{ }^{\mathrm{a}} \text { Geometria descriptiva e estereotomia }\end{array}$ \\
\hline $\begin{array}{l}\text { 2. }{ }^{\circ} \text { Grupo: Mecanica e astronomia } \\
\text { 7. }{ }^{\mathrm{a}} \text { Mecanica racional } \\
\text { 8. }{ }^{\mathrm{a}} \text { Physica Mathematica }\end{array}$ & $\begin{array}{l}\text { 9. } .^{\mathrm{a}} \text { Astronomia e geodesia } \\
\text { 10. } .^{\mathrm{a}} \text { Mecanica celeste }\end{array}$ \\
\hline \multicolumn{2}{|c|}{ 2.a secção: Sciencias Physico - Chimicas } \\
\hline $\begin{array}{l}\text { 1. }{ }^{\circ} \text { Grupo: Physica } \\
\text { Physica (Curso Geral) } \\
\text { 11. a Physica dos sólidos, e dos fluidos } \\
\text { 12. a Acustica, Optica e Calor }\end{array}$ & $\begin{array}{l}\text { 13. }{ }^{\text {a }} \text { Electricidade } \\
14 .^{\text {a }} \text { Physica Biológica }\end{array}$ \\
\hline $\begin{array}{l}\text { 2. }{ }^{\circ} \text { Grupo: Chimica } \\
\text { 15. } .^{a} \text { Chimica (Curso Geral) } \\
\text { 16. } .^{\text {a }} \text { Chimica Inorganica } \\
\text { 17. } .^{\text {C Chimica Organica }}\end{array}$ & $\begin{array}{l}\text { 18. }{ }^{a} \text { Chimica Physica } \\
\text { 19. }{ }^{a} \text { Chimica Biológica } \\
\text { 20. } .^{a} \text { Analyse chimica (qualitativa e quanti- } \\
\text { tativa) }\end{array}$ \\
\hline \multicolumn{2}{|c|}{ 3. a Secção: Sciencias Historico - naturaes } \\
\hline $\begin{array}{l}\text { 1. }{ }^{\circ} \text { Grupo: Sciencias Geologicas } \\
\text { Mineralogia e Geologia (Curso Geral) } \\
\text { 21. }{ }^{\mathrm{a}} \text { Cristallographia } \\
\text { 22. }{ }^{\mathrm{a}} \text { Mineralogia e Petrologia } \\
\text { 23. } .^{\mathrm{a}} \text { Geographia Physica }\end{array}$ & $\begin{array}{l}\text { 24. }{ }^{\text {a }} \text { Geologia } \\
25 \text {. }^{\text {a }} \text { Palentologia }\end{array}$ \\
\hline $\begin{array}{l}\text { 2. }{ }^{\circ} \text { Grupo Sciencias Biologicas } \\
\text { Botanica (Curso Geral) } \\
\text { 26. }{ }^{a} \text { Morphologia e physiologia vegetaes } \\
\text { Zoologia (Curso Geral) } \\
\text { 27. }{ }^{a} \text { Zoologia dos Invertebrados } \\
\text { 28. } .^{a} \text { Botanica especial e geographia botânica }\end{array}$ & $\begin{array}{l}\text { 29. a Zoologia dos Invertebrados } \\
\text { 30. a Zoologia dos Vertebrados e Geographia } \\
\text { Zoologica } \\
\text { 31. a Anthropologia }\end{array}$ \\
\hline
\end{tabular}

O relatório da Faculdade de Ciências da Universidade de Coimbra, de Henrique Teixeira Bastos, referente aos anos de 1911/1913 caracteriza os aspectos fundamentais na organização da nova Faculdade de Ciências. Na reforma de 1911 o ensino prático revestia-se de uma importância fulcral pois providenciaram-se, para além das demonstraçōes do anfiteatro que deviam acompanhar as liçóes magistrais, actividades de iniciação de alunos nas técnicas experimentais para mostrar como é que a ciência progride e instigar vocaçóes para trabalhos de investigação científica, exequível, na prática, com a introdução de trabalhos práticos obrigatórios. 


\section{Bibliografia}

AYRES, Bernardo. A Circulação Atmospherica e a Previsão do Tempo. Coimbra. Imprensa da Universidade. 1892.

BASTO, Álvaro José da Silva. Os raios cathódicos e os raios $X$ de Röntgen. Coimbra. Imprensa da Universidade. 1897.

BASTO, Egas Ferreira Pinto. Theoria dos Electrôes. (1. a parte). Coimbra. Imprensa da Universidade. 1908.

BASTO, Egas Ferreira Pinto. Theoria dos Electróes. (2. ${ }^{a}$ parte). Coimbra. Imprensa da Universidade. 1908.

BASTOS, Henrique Teixeira. Raios $X$ de Rontgen. O Instituto - Revista Scientifica e Literaria, volume XLIII, p 38-41, 275-279.

BASTOS, Henrique Teixeira. Theoria Electromagnetica da Luz. Coimbra. Imprensa da Universidade. 1885 .

CARVAlHO, Joaquim Augusto Simões de. Memória Histórica da Faculdade de Philosofia. Coimbra, Imprensa da Universidade, 1872.

CARVALHO, Rómulo de. A actividade pedagógica da Academia das Ciências de Lisboa nos séculos XVIII e XIX. Lisboa, 1979.

CARVALHO, Rómulo de. A física experimental em Portugal no século XVIII. Lisboa, Instituto da Cultura e Língua Portuguesa, 1982.

CARVALHO, Rómulo de. História do Gabinete de Física da Universidade de Coimbra desde a sua fundação (1772) até ao jubileu do professor italiano Giovanni António Dalla Bella (1790). Coimbra, Biblioteca Geral da Universidade de Coimbra, 1978.

CASTRO FREIRE, Francisco de. Memoria historica da Faculdade de Mathematica, nos cem annos decorridos desde a Reforma da Universidade em 1772 até o presente. Coimbra, 1872.

COMPÊNDIO histórico do estado da Universidade de Coimbra no tempo da invasão dos denominados Jesuitas, e dos estragos feitos nas Ciências e nos professores e directores que a regiam, pelas maquinações e publicaçôes dos novos Estatutos por eles fabricados (Coimbra, 1771).

COSTA, A.M. Amorim.As Ciências Naturais da Reforma Pombalina da Universidade. In O Marquês de Pombal e a Universidade. Coord. Ana Cristina Araújo. Coimbra. Imprensa da Universidade. 2000. p. 165-190.

COSTA, A.M. Amorim. De Stahl a Lavoisier em Portugal Setecentista. Química, Boletim da Sociedade Portuguesa de Química n. ${ }^{\circ} 32 / 33$ (Série II), 8-10 (1988).

COSTA, A.M. Amorim. Primórdios da ciência química em Portugal A. ICALP - Colecção Biblioteca Breve - Volume 92. 1984. p. 30.

COSTA, A.M. Amorim. Thomé Rodrigues Sobral (1759-1829): A Química ao Serviço da Comunidade. História e Desenvolvimento da Ciência em Portugal. Publicações II Centenário da Academia de Ciências de Lisboa, Lisboa, vol. I, 373-401. (1986).

LACERDA, Aarão Ferreira de. Equaçôes Geraes da Thermodynamica. Coimbra. Imprensa da Universidade. 1886.

LEMOS, D. Francisco de. Relação Geral do Estado da Universidade de Coimbra desde o principio da Nova Reformação até o Mez de Setembro de 1777. Lisboa, Teófilo Braga, 1894; reed. Coimbra, 1980.

MARTINS, Décio R.. A Reforma Pombalina da Universidade de Coimbra: Que inovação no ensino das ciências Físico-matemáticas? Congresso Internacional - O Marquês de Pombal e a sua época. Pombal 10, 11 e 12 de Novembro de 1999. p. 323-339. 
MARTINS, Décio R.. As ciências Físico-matemáticas em Portugal e a Reforma Pombalina. In O Marquês de Pombal e a Universidade. Coord. Ana Cristina Araújo. Coimbra. Imprensa da Universidade. 2000. p. 193-262.

RODRIGUES, Manuel Augusto. Actas das Congregações da Faculdade de Matemática: 1772-1820. Coimbra, 1982-1983, 2 volumes.

SILVA, Mário Augusto da. A actividade cientifica dos primeiros directores do gabinete de Física que a reforma pombalina criou em Coimbra em 1772. Revista da Faculdade de Ciências da Universidade de Coimbra. 1940, vol. IX; n. ${ }^{\circ} 1$.

SILVA, Mário Augusto da. Um novo museu em Coimbra: o Museu Pombalino de Física da Faculdade de Ciências da Universidade. Coimbra, Laboratório de Física da Universidade de Coimbra, 1939.

SOUSA, Jachinto António de. Gabinete de Physica da Faculdade de Philosophia na Universidade de Coimbra. Coimbra, Universidade, 1878.

VASCONCELOS, Mathias de Carvalho de. Primeiro relatório dirigido à Faculdade de Philosophia da Universidade de Coimbra pelo seu vogal em comissão fora do reino. O Instituto, t. VII, p. 134.

VEIGA, Luís Alte da.. Le Cabinet de Physique Expérimentale de L' Université de Coimbra: En revivant les XVIIIe et XIXe siècles et de le développement de la Physique. Les Mécanismes du Génie - Instruments Scientifiques du XVIII et XIX ${ }^{\mathrm{e}}$ Siècles. (Europália 91 - Portugal). Charleroi. Bélgica. 1991.

VIEGAS, António dos Santos. Viagem scientífica do Dr. António dos Santos Viegas - Primeiro relatório: Dezembro de 1866 a Maio de 1867. Diário de Lisboa. Folha official do governo portuguez. Outubro 1867, n. ${ }^{\circ} 229$, p. 2966.

VIEGAS, António dos Santos. Viagem scientífica do Dr. António dos Santos Viegas - Segundo relatório: Junho a Novembro de 1867. Diário de Lisboa. Folha official do governo portuguez. 21 Março 1867, n. ${ }^{\circ}$ 66, p. 553. 